Supporting Information for:

\title{
Encapsulation of Aromatic Guests in Bisporphyrin Cavity of a Double-Stranded Spiroborate Helicate: Thermodynamic and Kinetic Studies and Encapsulation Mechanism
}

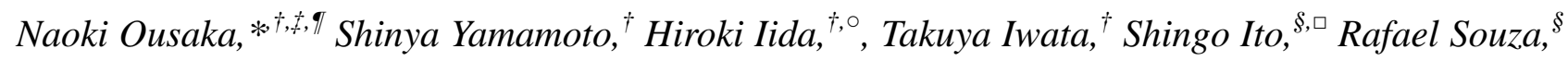
Yuh Hijikata, ${ }^{*}, \sharp, \Delta$ Stephan Irle, ${ }^{\S, \#, \diamond}$ and Eiji Yashima ${ }^{*}+, *$

${ }^{\dagger}$ Department of Molecular Design and Engineering, Graduate School of Engineering, Nagoya University, Nagoya 464-8603, Japan. ${ }^{\ddagger}$ Department of Molecular and Macromolecular Chemistry, Graduate School of Engineering, Nagoya University, Nagoya 464-8603, Japan. ${ }^{\S}$ Department of Chemistry, Graduate School of Science, Nagoya University, Nagoya 464-8602, Japan. "Institute of Transformative Bio-Molecules (WPI-ITbM), Nagoya University, Nagoya 464-8601, Japan.

Present Address: "IMolecular Engineering Institute, Kyushu Institute of Technology, Tobata-ku, Kitakyushu, 804-8550, Japan. ${ }^{\circ}$ Department of Chemistry, Graduate School of Natural Science and Technology, Shimane University, 1060 Nishikawatsu, Matsue 690-8504, Japan. ${ }^{\square}$ Theoretical Molecular Science Laboratory, RIKEN Cluster for Pioneering Research, Wako, Saitama, 351-0198, Japan. ${ }^{\Delta}$ Institute for Chemical Reaction Design and Discovery (WPI-ICReDD), Hokkaido University, Sapporo, 001-0021, Japan. ${ }^{\circledR}$ Computational Sciences \& Engineering Division, Oak Ridge National Laboratory, Oak Ridge, TN 37831-6129, USA.

E-mail: ousaka.naoki@gmail.com; hijikata@icredd.hokudai.ac.jp; yashima@chembio.nagoya-u.ac.jp 


\section{Table of Contents}

1. Determination of the Association Constants of $\mathbf{1}_{\mathbf{N a} 2}$ with Various Guests (Figures S1-S3) S3

2. ${ }^{1} \mathrm{H}$ Spectra of $\mathbf{1}_{\mathbf{N a} 2}$ with Various Guests (Figures S4-S21)

3. Water-mediated Inclusion Complex Formation of $\mathbf{1}_{\mathrm{Na} 2}$ with

Bulky G18 (Figures S22-S23)

4. X-ray Crystallographic Data (Figure S24, Table S1)

5. Theoretical Studies on the Mechanism of Guest Encapsulation within the Helicate (Figures S25-S30, Table S2-S5)

6. General Procedure for Exchange Spectroscopy (EXSY) Experiments (Figures S31-S33)

7. $\mathrm{CD}$ and Absorption Spectra of $\mathbf{1}_{\mathrm{Na} 2}$ upon Inclusion Complex Formation with Various Guests (Figures S34- S36, Table S6)

8. $\quad$ 2D NMR Spectra of $\mathbf{1}_{\mathbf{N a} 2}$ Complexed with G6 and G15 (Figures S37- S40) S47

9. Supporting References

10. Spectroscopic Data 


\section{Determination of the Association Constants of $\mathbf{1}_{\mathrm{Na} 2}$ with Various Guests}

The association constants $\left(K_{\mathrm{a}}\right)$ of $\mathbf{1}_{\mathrm{Na} 2}$ with various guests $(\mathbf{G X})$ in $\mathrm{CH}_{3} \mathrm{CN}$ at $25{ }^{\circ} \mathrm{C}$ were estimated by absorption (Figure S1) and fluorescence (Figure S2) titrations according to the previously reported method. ${ }^{\mathrm{S} 1}$ The $K_{\mathrm{a}}$ values of $\mathbf{1}_{\mathrm{Na} 2}$ with selected guests $(\mathbf{G 3}, \mathbf{G 4}, \mathbf{G 1 0}$, and G13) at different temperatures were also estimated by absorption or fluorescence titration, and then thermodynamic parameters for the inclusion complexation were estimated by van't Hoff plots of the obtained $K_{\mathrm{a}}($ Figure S3).

$$
\mathbf{1}_{\mathrm{Na} 2}+\mathrm{GX} \underset{\mathrm{CH}_{3} \mathrm{CN}}{\stackrel{K_{\mathrm{a}}}{\rightleftarrows}} \mathbf{1}_{\mathrm{Na2}} \supset \mathbf{G X} \quad K_{\mathrm{a}}=\frac{\left[\mathbf{1}_{\mathrm{Na} 2} \supset \mathbf{G X}\right]}{\left[\mathbf{1}_{\mathrm{Na} 2}\right][\mathbf{G X}]}
$$

$$
\begin{aligned}
\Delta A b s & =A b s_{\text {obs }}-A b s 1_{\text {Na2 }} \\
& =\frac{\left(A b s 1_{\text {Na2 }} \supset \mathbf{G X}-A b 1_{N_{\mathrm{Na}}}\right)}{2 K_{\mathrm{a}}\left[\mathbf{1}_{\mathrm{Na} 2}\right]_{0}}\left[1+K_{\mathrm{a}}\left[\mathbf{1}_{\mathrm{Na} 2}\right]_{0}+K_{\mathrm{a}}[\mathbf{G X}]_{0}-\left\{\left(1+K_{\mathrm{a}}\left[\mathbf{1}_{\mathrm{Na} 2}\right]_{0}+K_{\mathrm{a}}[\mathbf{G X}]_{0}\right)^{2-}-4 K_{\mathrm{a}}^{2}\left[\mathbf{1}_{\mathrm{Na} 2}\right]_{0}[\mathbf{G X}]_{0}\right\}^{1 / 2}\right]
\end{aligned}
$$

Absobs: observed absorbance

Abs1 Na2 : absorbance for $\mathbf{1}_{\mathrm{Na} 2}$

AbS $_{\mathrm{Na}_{2}} \supset \mathrm{GX}$ : absorbance for $\mathbf{1}_{\mathrm{Na} 2} \supset \mathbf{G X}$

(a)

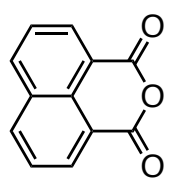

G2

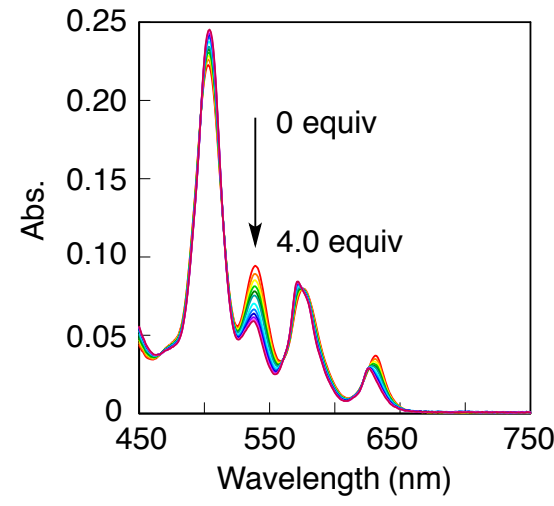

(c)<smiles>O=c1oc(=O)c2cc3c(=O)oc(=O)c3cc12</smiles>

G3
[1 $\left.\mathbf{N a 2}_{0}\right]_{0}$ total concentration of $\mathbf{1}_{\mathrm{Na}}$ $[\mathbf{G X}]_{0}$ : total concentration of $\mathbf{G X}$ $K_{\mathrm{a}}$ : association constant

(b)

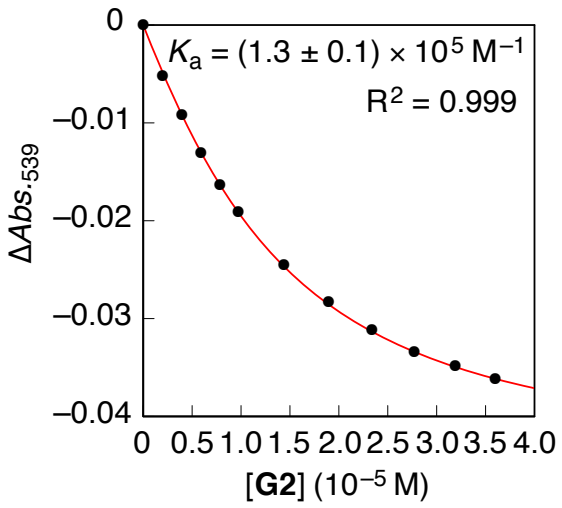

(d)

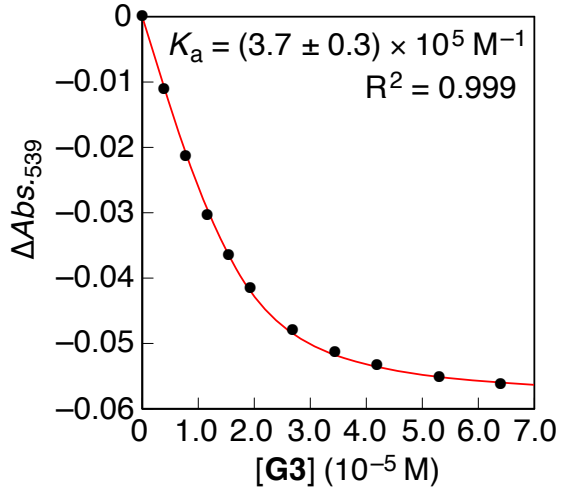

(Figure S1 to be continued) 
<smiles>Fc1c(F)c(F)c(F)c(F)c1F</smiles>

G7 (e)

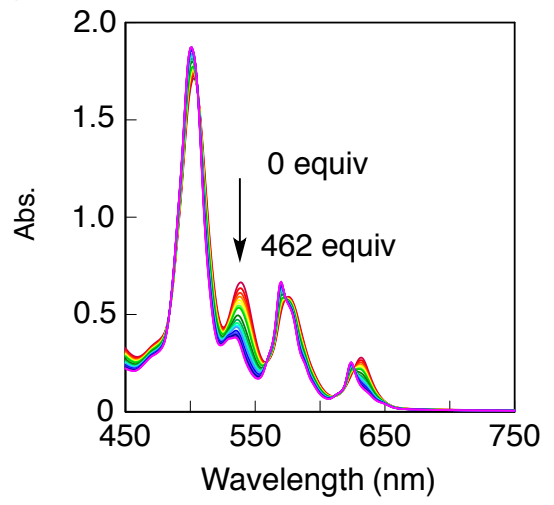

(g)

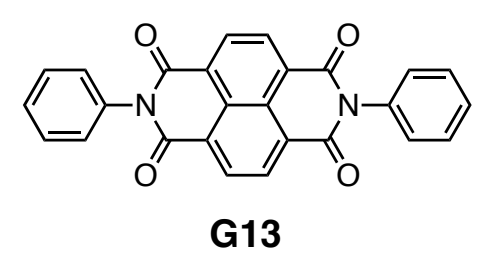

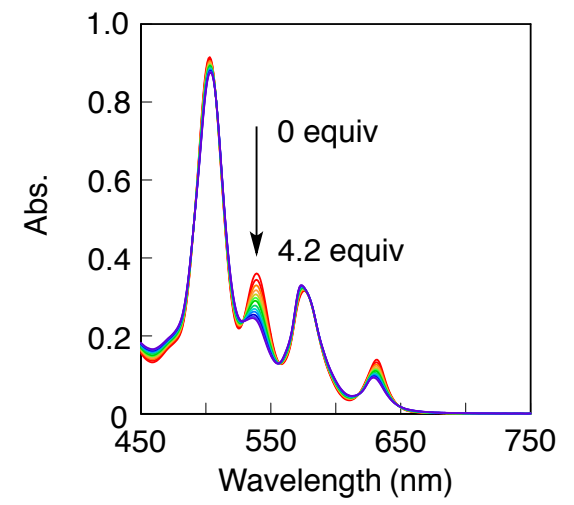

(f)

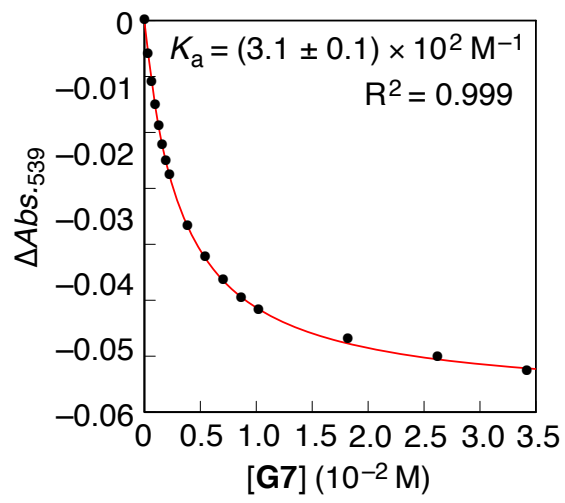

(h)

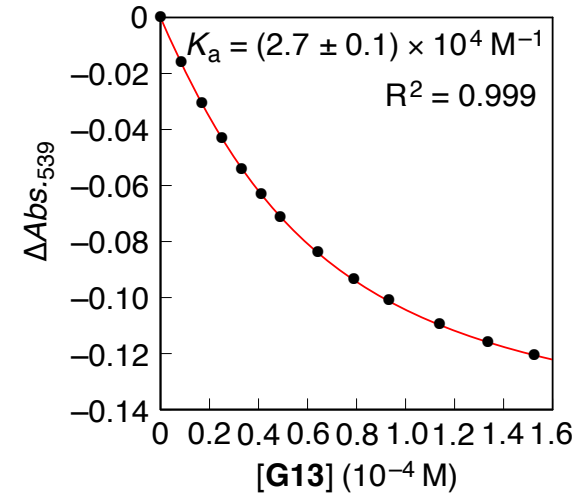

Figure S1. Absorption spectral changes of $\mathbf{1}_{\mathrm{Na} 2}(10 \mu \mathrm{M}$ (a), $18 \mu \mathrm{M}$ (c), $75 \mu \mathrm{M}$ (e), and $40 \mu \mathrm{M}(\mathrm{g}))$ upon the addition of $\mathbf{G 2}$ (a), G3 (c), G7 (e), and $\mathbf{G 1 3}$ (g) in $\mathrm{CH}_{3} \mathrm{CN}$ at $25^{\circ} \mathrm{C}$ measured in a $1.0-\mathrm{cm}$ quartz cell. Plots of absorbance changes $\left(\Delta \mathrm{Abs}_{539}\right)$ at $539 \mathrm{~nm}$ of $\mathbf{1}_{\mathrm{Na} 2}$ versus the concentrations of G2 (b), G3 (d), G7 (f), and G13 (h). The curves in the plots were obtained by the least-squares curve-fitting method based on a 1:1 stoichiometry, giving the association constants $\left(K_{\mathrm{a}}\right)$ of $\mathbf{1}_{\mathrm{Na} 2}$ with G2, G3, G7, and $\mathbf{G 1 3}$ to be $(1.3 \pm 0.1) \times 10^{5} \mathrm{M}^{-1},(3.7 \pm 0.3) \times 10^{5} \mathrm{M}^{-1},(3.1 \pm 0.1) \times 10^{2} \mathrm{M}^{-1}$, and $(2.7 \pm 0.1) \times 10^{4} \mathrm{M}^{-1}$, respectively. 


$$
\begin{aligned}
& \mathbf{1}_{\mathrm{Na} 2}+\mathrm{GX} \underset{\mathrm{CH}_{3} \mathrm{CN}}{\stackrel{K_{\mathrm{a}}}{\rightleftarrows}} \mathbf{1}_{\mathrm{Na} 2} \supset \mathbf{G X} \\
& K_{\mathrm{a}}=\frac{\left[\mathbf{1}_{\mathrm{Na} 2} \supset \mathbf{G X}\right]}{\left[\mathbf{1}_{\mathrm{Na} 2}\right][\mathbf{G X}]} \\
& \Delta l=l_{\mathrm{obs}}-l_{1_{\mathrm{Na} 2}} \\
& =\frac{\left(1_{1_{\mathrm{Na} 2} \supset \mathrm{GX}-}-/_{\mathbf{N}_{\mathrm{Na}} 2}\right)}{2 K_{\mathrm{a}}\left[\mathbf{1}_{\mathrm{Na} 2}\right]_{0}}\left[1+K_{\mathrm{a}}\left[\mathbf{1}_{\mathrm{Na} 2}\right]_{0}+K_{\mathrm{a}}[\mathbf{G X}]_{0}-\left\{\left(1+K_{\mathrm{a}}\left[\mathbf{1}_{\mathrm{Na} 2}\right]_{0}+K_{\mathrm{a}}[\mathbf{G X}]_{0}\right)^{2}-4 K_{\mathrm{a}}^{2}\left[\mathbf{1}_{\mathrm{Na} 2}\right]_{0}[\mathbf{G X}]_{0}\right\}^{1 / 2}\right]
\end{aligned}
$$

(a)

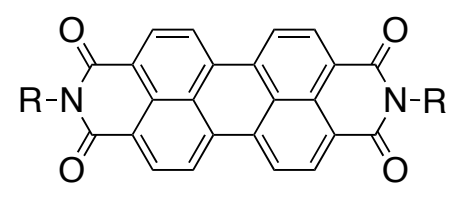

$\mathrm{R}:-\xi \mathrm{O}_{\mathrm{O}} \sim \mathrm{O}^{\prime} \mathrm{O}^{\prime}$

G6

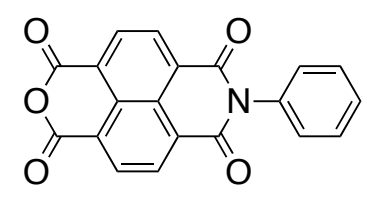

G10

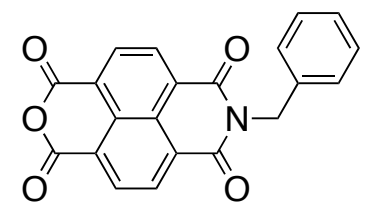

G11

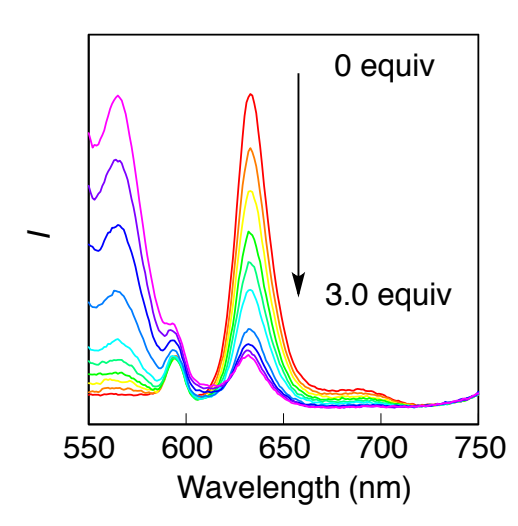

(c)

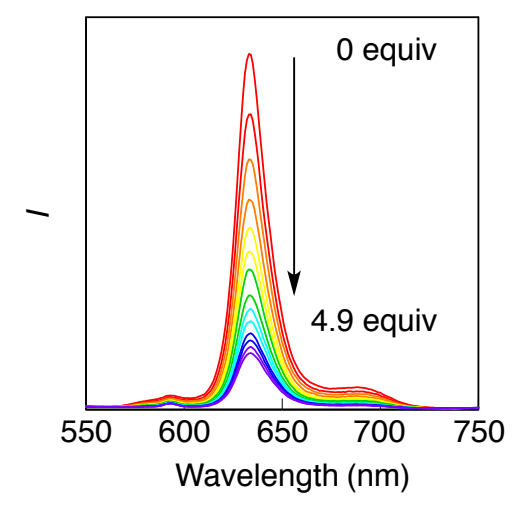

(e)

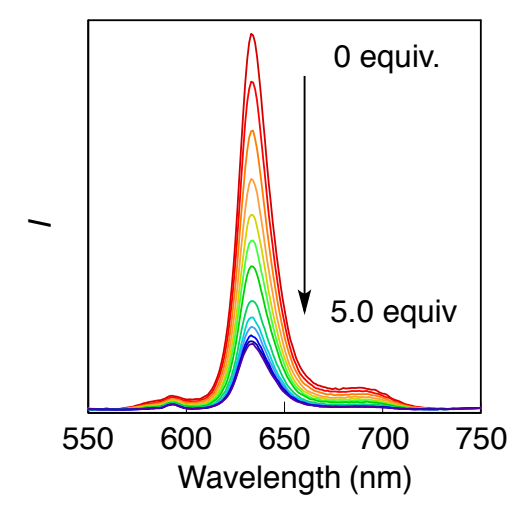

(b)

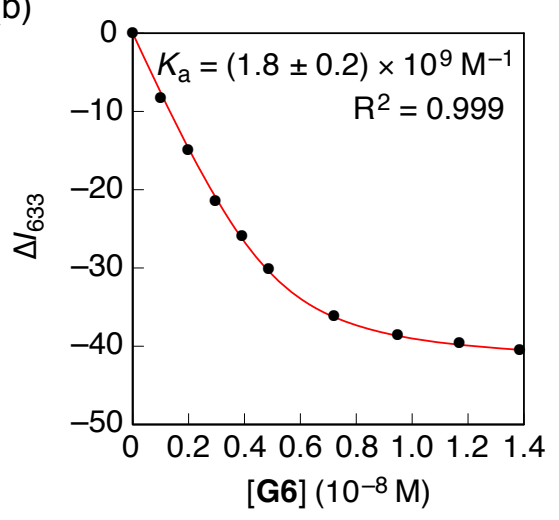

(d)

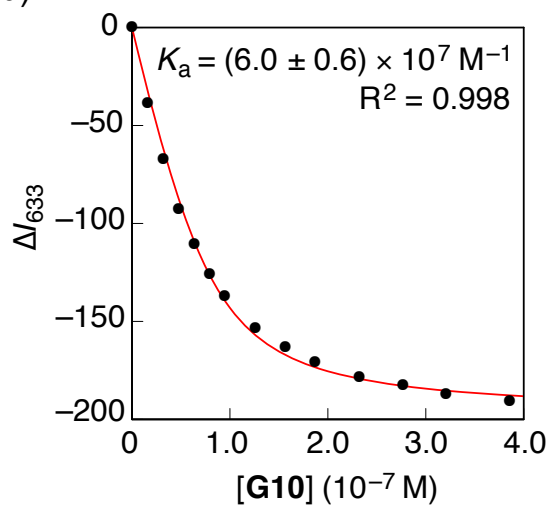

(f)

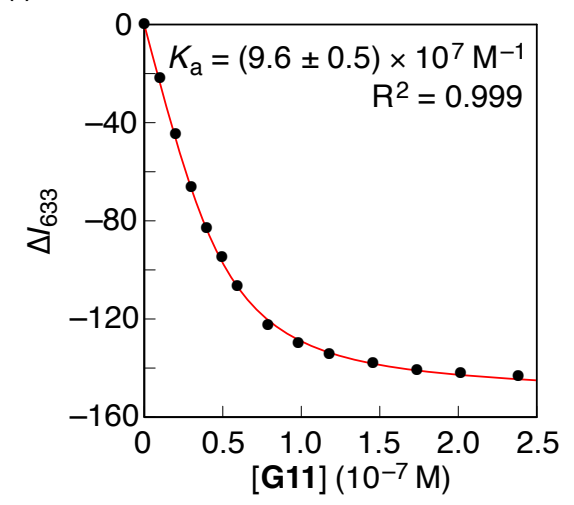

(Figure S2 to be continued) 
(g)

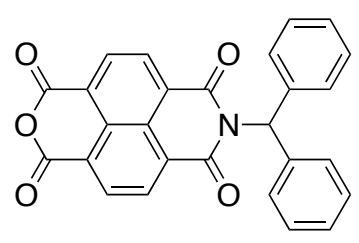

G12
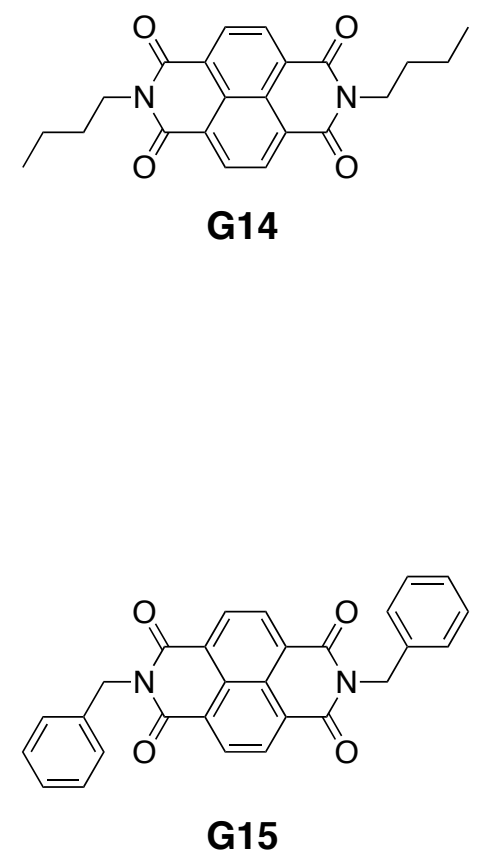

(i)

(k)
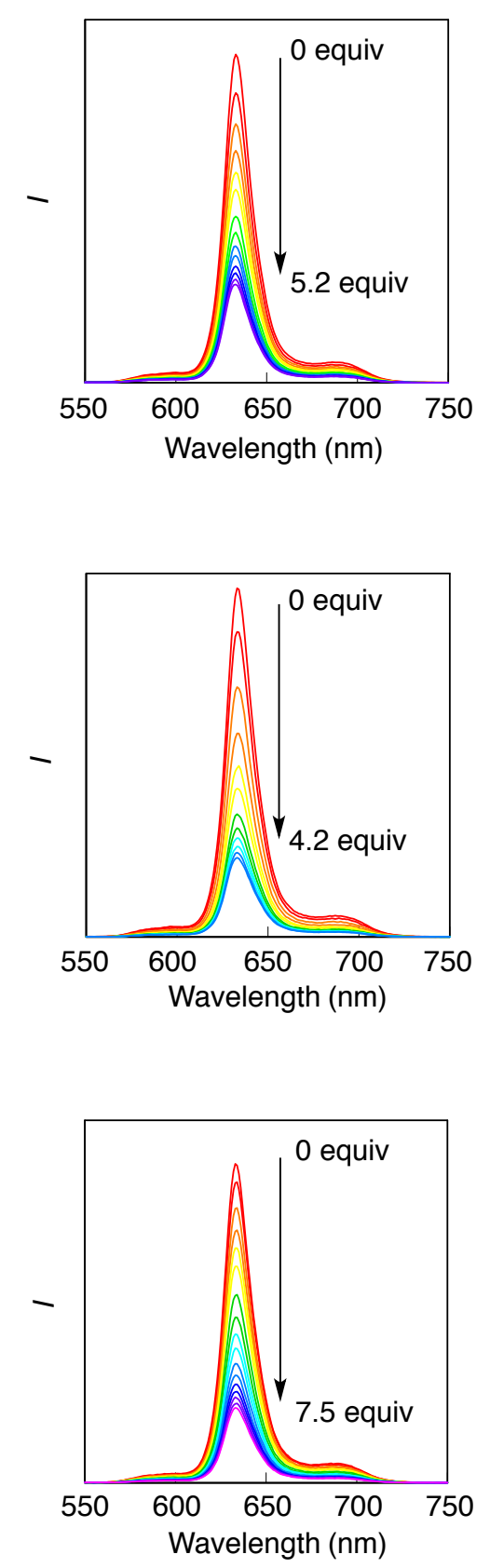

(h)

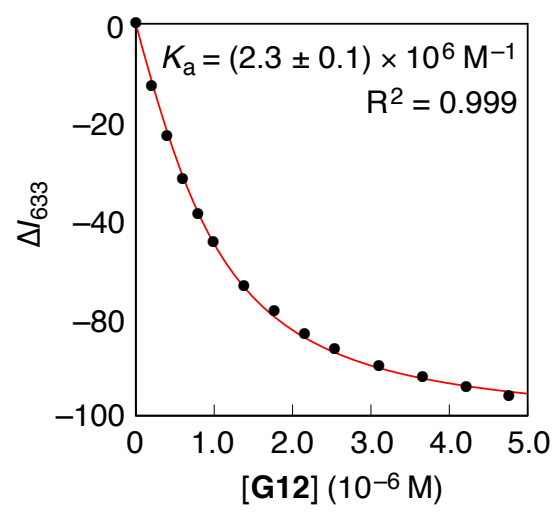

(j)

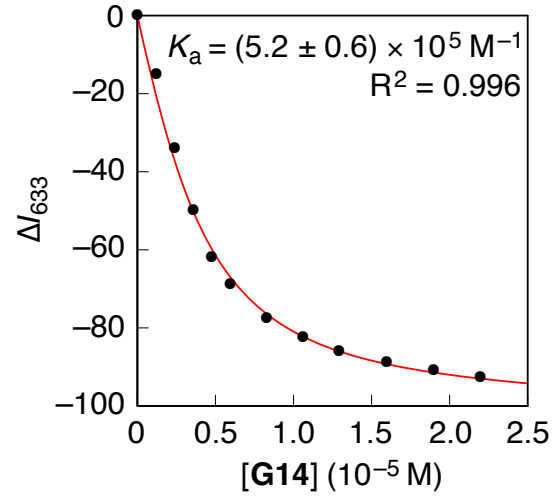

(I)

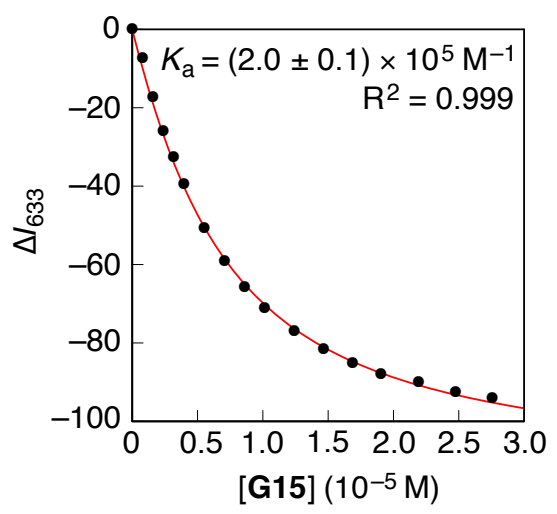

Figure S2. Fluorescence spectral changes of $\mathbf{1}_{\mathrm{Na} 2}(5.0 \mathrm{nM}$ (a), $78 \mathrm{nM}$ (c), $50 \mathrm{nM}$ (e), $91 \mu \mathrm{M}(\mathrm{g}), 3.6$ $\mu \mathrm{M}(\mathrm{i})$, and $\left.3.6 \mu \mathrm{M}(\mathrm{k}), \lambda_{\mathrm{ex}}=395 \mathrm{~nm}\right)$ upon the addition of G6 (a), G10 (c), G11 (e), G12 (g), G14 (i), and $\mathbf{G 1 5}(\mathrm{k})$ in $\mathrm{CH}_{3} \mathrm{CN}$ at $25^{\circ} \mathrm{C}$ measured in a 1.0-cm quartz cell. Plots of fluorescence intensity changes $\left(\Delta_{\text {Int }}\right)$ at $633 \mathrm{~nm}$ of $\mathbf{1}_{\mathrm{Na} 2}$ versus the concentrations of $\mathbf{G 6}(\mathrm{b}), \mathbf{G 1 0}(\mathrm{d}), \mathbf{G 1 1}(\mathrm{f}), \mathbf{G 1 2}(\mathrm{h})$, G14 (j), and G15 (1). The curves in the plots were obtained by the least-squares curve-fitting method based on a 1:1 stoichiometry, giving the association constants $\left(K_{\mathrm{a}}\right)$ of $\mathbf{1}_{\mathrm{Na} 2}$ with G6, G10, G11, G12, G14, and G15 to be $(1.8 \pm 0.2) \times 10^{9} \mathrm{M}^{-1},(6.0 \pm 0.6) \times 10^{7} \mathrm{M}^{-1},(9.6 \pm 0.5) \times 10^{7} \mathrm{M}^{-1}$, $(2.3 \pm 0.1) \times 10^{6} \mathrm{M}^{-1},(5.2 \pm 0.6) \times 10^{5} \mathrm{M}^{-1}$, and $(2.0 \pm 0.1) \times 10^{5} \mathrm{M}^{-1}$, respectively. 
a) $1_{\mathrm{Na} 2} \supset \mathrm{G} 3$<smiles>O=c1oc(=O)c2cc3c(=O)oc(=O)c3cc12</smiles>

G3

$\Delta H^{\circ}=-36.3 \pm 1.6 \mathrm{kJmol}^{-1}$ $\Delta S^{\circ}=-16.0 \pm 5.4 \mathrm{Jmol}^{-1} \mathrm{~K}^{-1}$ $\Delta G_{298}^{\circ}=-31.5 \pm 3.3 \mathrm{kJmol}^{-1}$

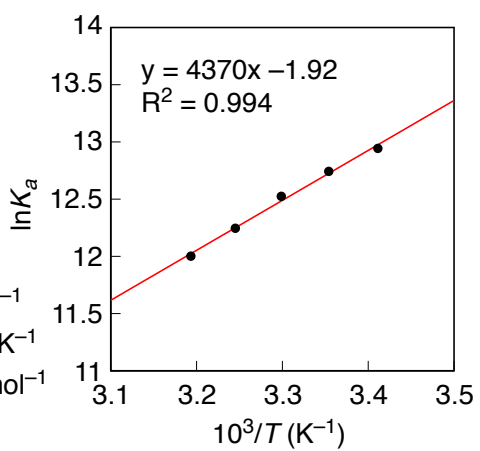

C) $\mathbf{1}_{\mathrm{Na} 2} \supset \mathrm{G} 10$

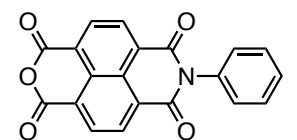

G10

$\Delta H^{\circ}=-74.1 \pm 3.0 \mathrm{kJmol}^{-1}$ $\Delta S^{\circ}=-98.9 \pm 9.7 \mathrm{Jmol}^{-1} \mathrm{~K}^{-1}$ $\Delta G^{\circ}{ }_{298}=-45.0 \pm 5.9 \mathrm{kJmol}^{-1}$

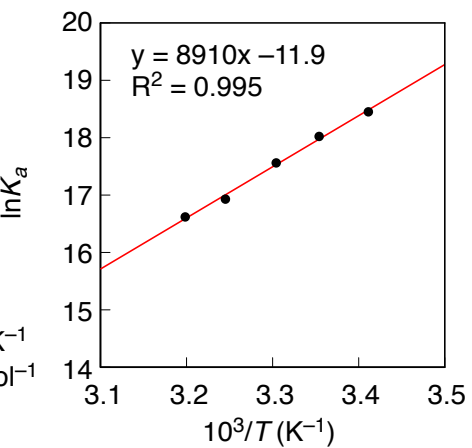

b) $\mathbf{1}_{\mathrm{Na} 2} \supset \mathrm{G} 4$

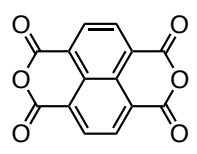

G4

$\Delta H^{\circ}=-71.8 \pm 3.8 \mathrm{kJmol}^{-1}$ $\Delta S^{\circ}=-59.1 \pm 12.4 \mathrm{Jmol}^{-1} \mathrm{~K}^{-1}$ $\Delta G_{298}^{\circ}=-54.1 \pm 7.4 \mathrm{kJmol}^{-1}$

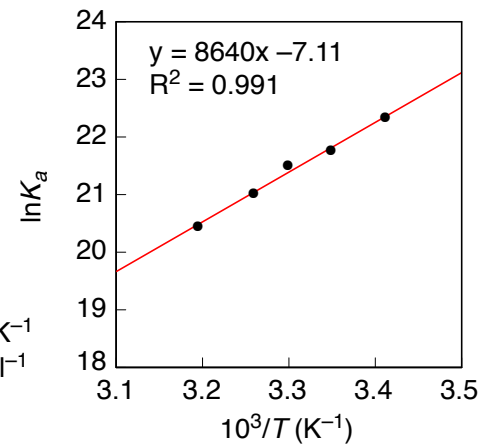

d) $\mathbf{1}_{\mathrm{Na} 2} \supset \mathrm{G} 13$

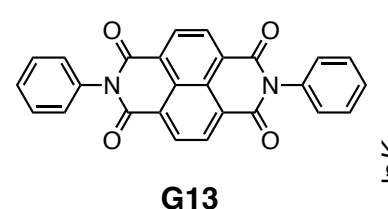

$\Delta H^{\circ}=-41.2 \pm 0.7 \mathrm{kJmol}^{-1}$ $\Delta S^{\circ}=-53.5 \pm 2.4 \mathrm{Jmol}^{-1} \mathrm{~K}^{-1}$ $\Delta G_{298}^{\circ}=-25.3 \pm 1.5 \mathrm{kJmol}^{-1}$

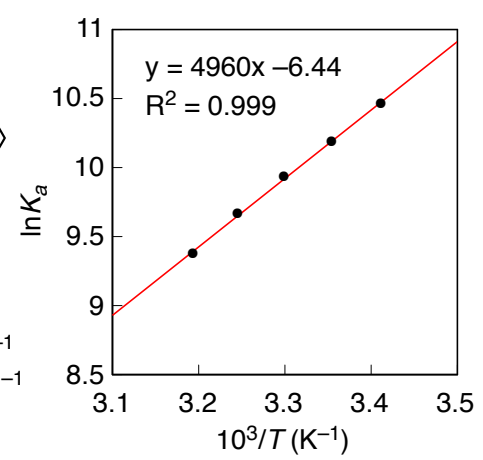

Figure S3. The van't Hoff plots for the inclusion complexation of $\mathbf{1}_{\mathrm{Na} 2}$ with $\mathbf{G 3}$ (a), G4 (b), G10 (c), and $\mathbf{G 1 3}$ (d) in $\mathrm{CH}_{3} \mathrm{CN}$ over temperature range of 20 to $40{ }^{\circ} \mathrm{C} ;\left[\mathbf{1}_{\mathrm{Na} 2}\right]=10 \mu \mathrm{M}(\mathrm{a}), 3.0 \mathrm{nM}$ (b), $40 \mathrm{nM}(\mathrm{c})$, and $40 \mu \mathrm{M}(\mathrm{d})$. 


\section{2. ${ }^{1} \mathrm{H}$ Spectra of $\mathbf{1}_{\mathrm{Na} 2}$ with Various Guests}
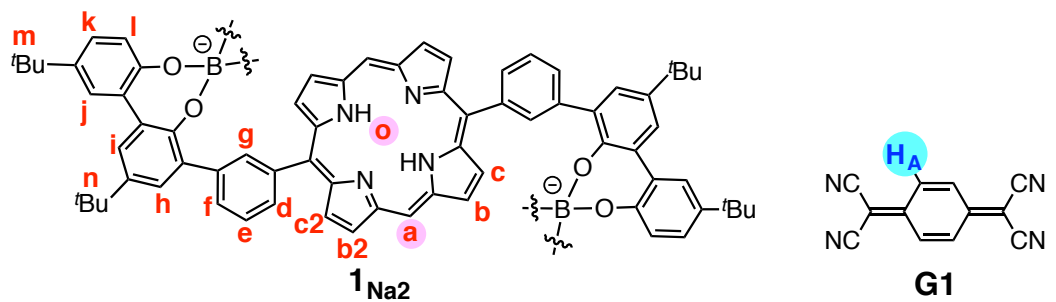

(a) G1

$\mathrm{H}_{\mathrm{A}}$

${ }^{t} \mathrm{Bu}$

included G1 NH

(b) $\mathbf{1}_{\mathrm{Na} 2}$

(c) (b) + G1

(0.5 equiv)

(d) (b) + G1

(1.0 equiv)
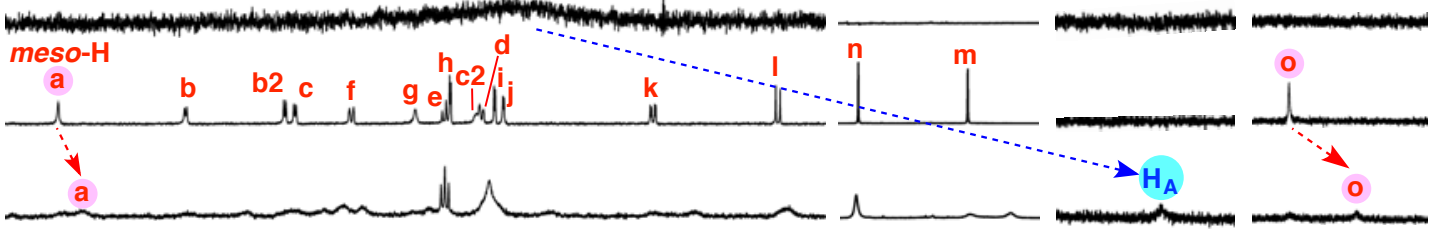

(e) (b) + G1

(2.0 equiv)

(f) (b) + G1

(5.0 equiv)
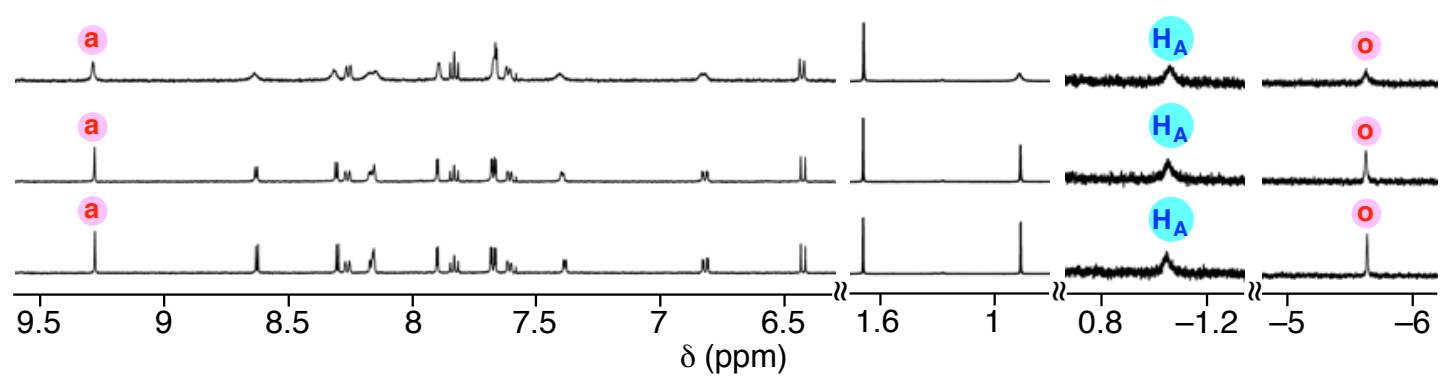

Figure S4. Partial ${ }^{1} \mathrm{H}$ NMR spectra $\left(500 \mathrm{MHz}, \mathrm{CD}_{3} \mathrm{CN}, 25^{\circ} \mathrm{C}\right)$ of $\mathbf{G 1}(0.5 \mathrm{mM})(\mathrm{a}), \mathbf{1}_{\mathrm{Na} 2}(0.2 \mathrm{mM})$ (b), and (b) +0.5 (c), 1.0 (d), 2.0 (e), and 5.0 equiv of G1 (f).
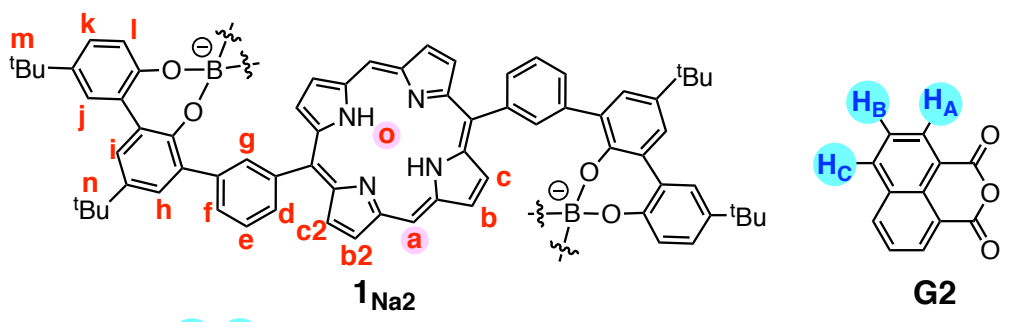

(a) G2

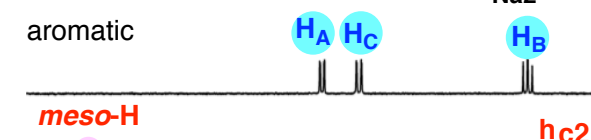

(b) $\mathbf{1}_{\mathrm{Na} 2}$
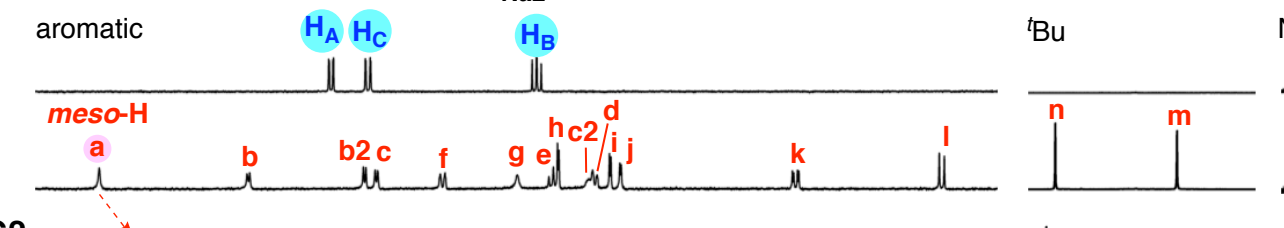

$\mathrm{NH}$

(c) (b) + G2

( 0.5 equiv)

(d) (b) + G2

(1.0 equiv)

(e) (b) + G2

(2.0 equiv)
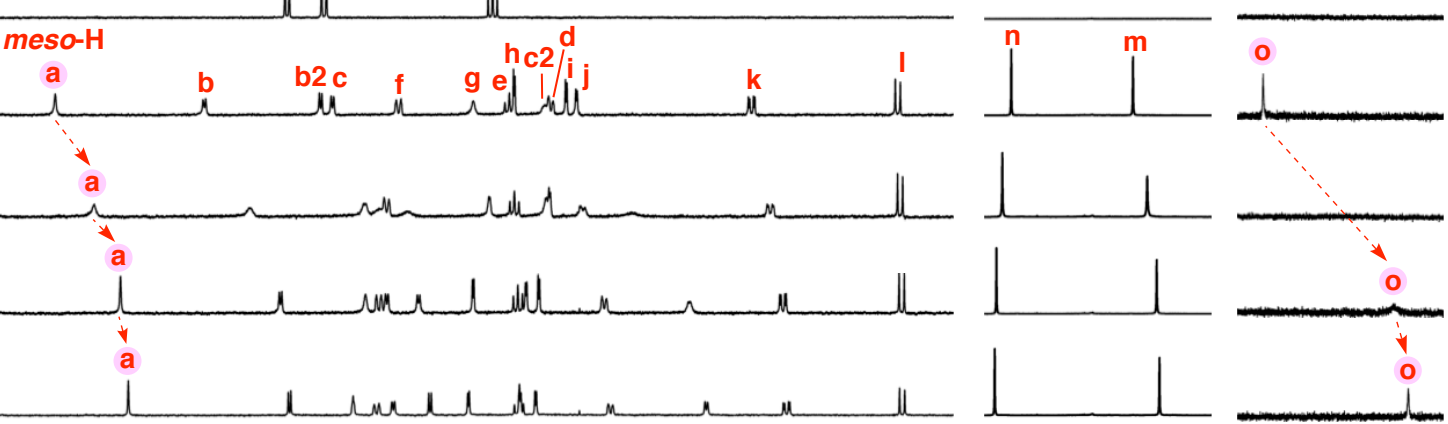

(f) (b) + G2

(5.0 equiv)
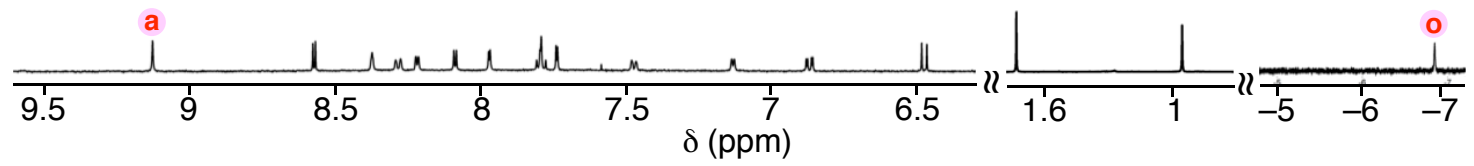

Figure S5. Partial ${ }^{1} \mathrm{H}$ NMR spectra $\left(500 \mathrm{MHz}, \mathrm{CD}_{3} \mathrm{CN}, 25^{\circ} \mathrm{C}\right)$ of $\mathbf{G 2}(0.5 \mathrm{mM})(\mathrm{a}), \mathbf{1}_{\mathrm{Na} 2}(0.2 \mathrm{mM})$ (b), and (b) + 0.5 (c), 1.0 (d), 2.0 (e), and 5.0 equiv of $\mathbf{G 2}$ (f). The peaks of the included G2 could not be observed due to the broadening of their peaks. 

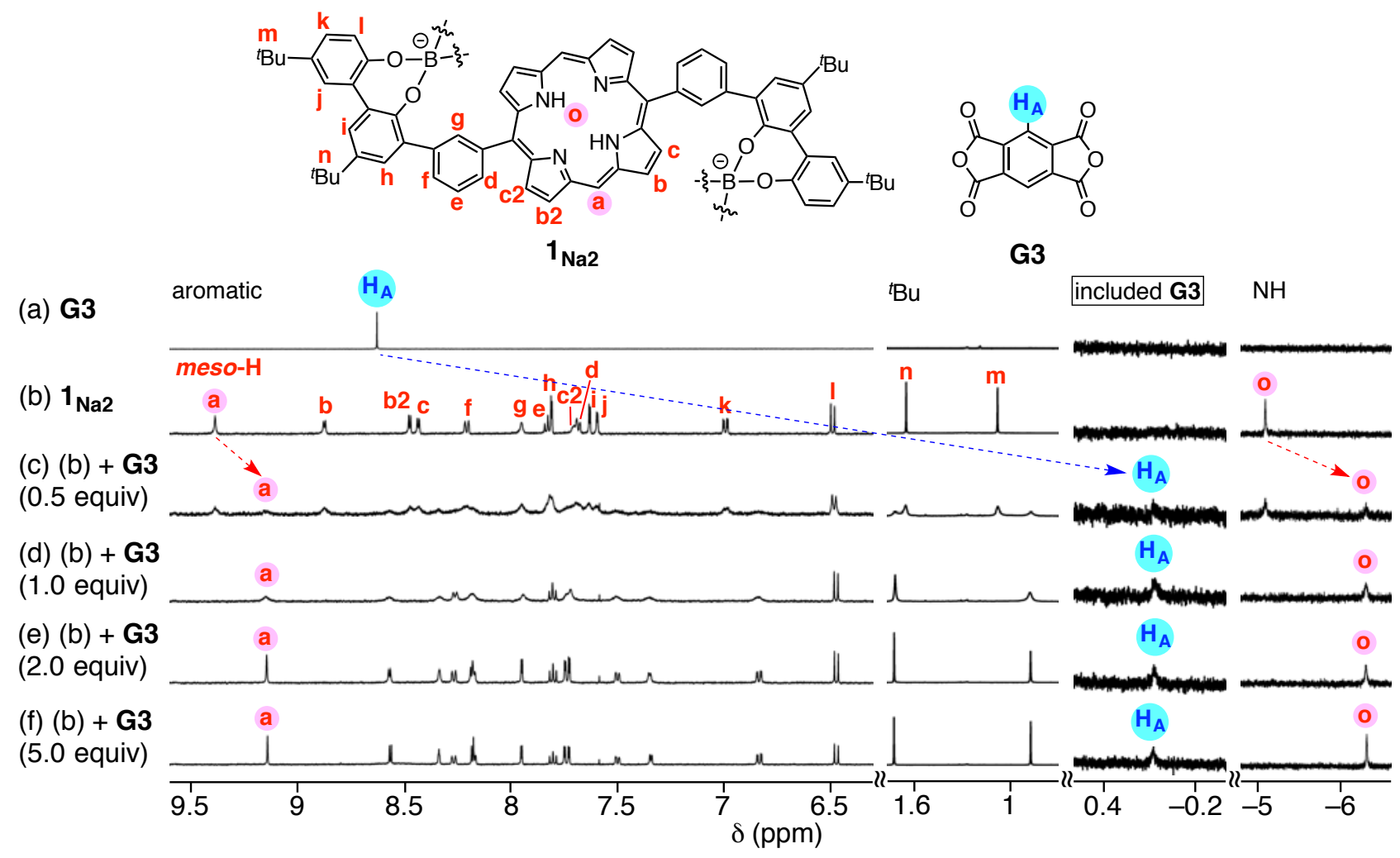

Figure S6. Partial ${ }^{1} \mathrm{H}$ NMR spectra $\left(500 \mathrm{MHz}, \mathrm{CD}_{3} \mathrm{CN}, 25{ }^{\circ} \mathrm{C}\right)$ of $\mathbf{G 3}(0.5 \mathrm{mM})(\mathrm{a}), \mathbf{1}_{\mathrm{Na} 2}(0.2 \mathrm{mM})$ (b), and (b) +0.5 (c), 1.0 (d), 2.0 (e), and 5.0 equiv of $\mathbf{G 3}$ (f).
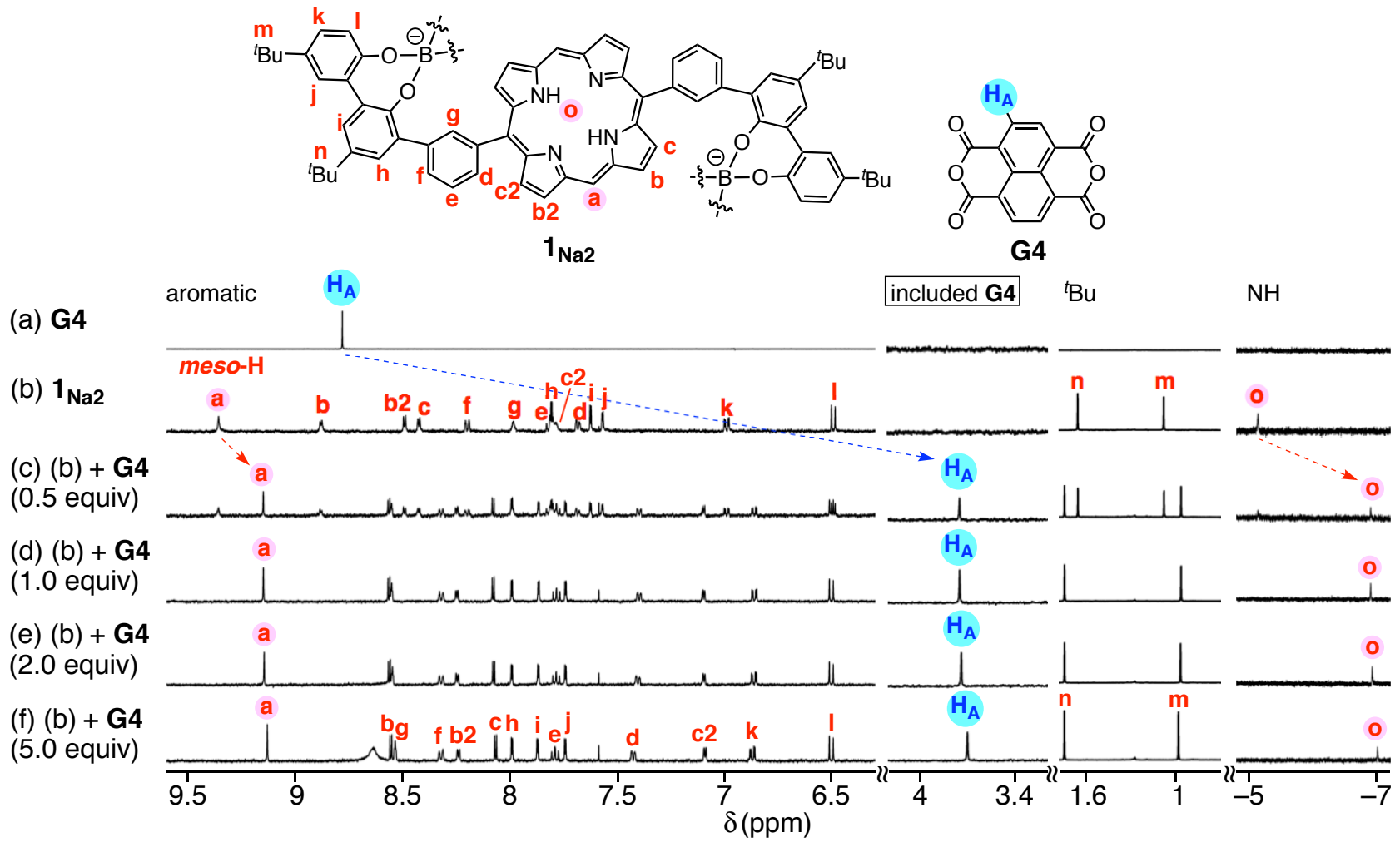

Figure S7. Partial ${ }^{1} \mathrm{H}$ NMR spectra $\left(500 \mathrm{MHz}, \mathrm{CD}_{3} \mathrm{CN}, 25{ }^{\circ} \mathrm{C}\right)$ of $\mathbf{G 4}(0.5 \mathrm{mM})(\mathrm{a}), \mathbf{1}_{\mathrm{Na} 2}(0.2 \mathrm{mM})$ (b), and (b) + 0.5 (c), 1.0 (d), 2.0 (e), and 5.0 equiv of $\mathbf{G 4}$ (f). 

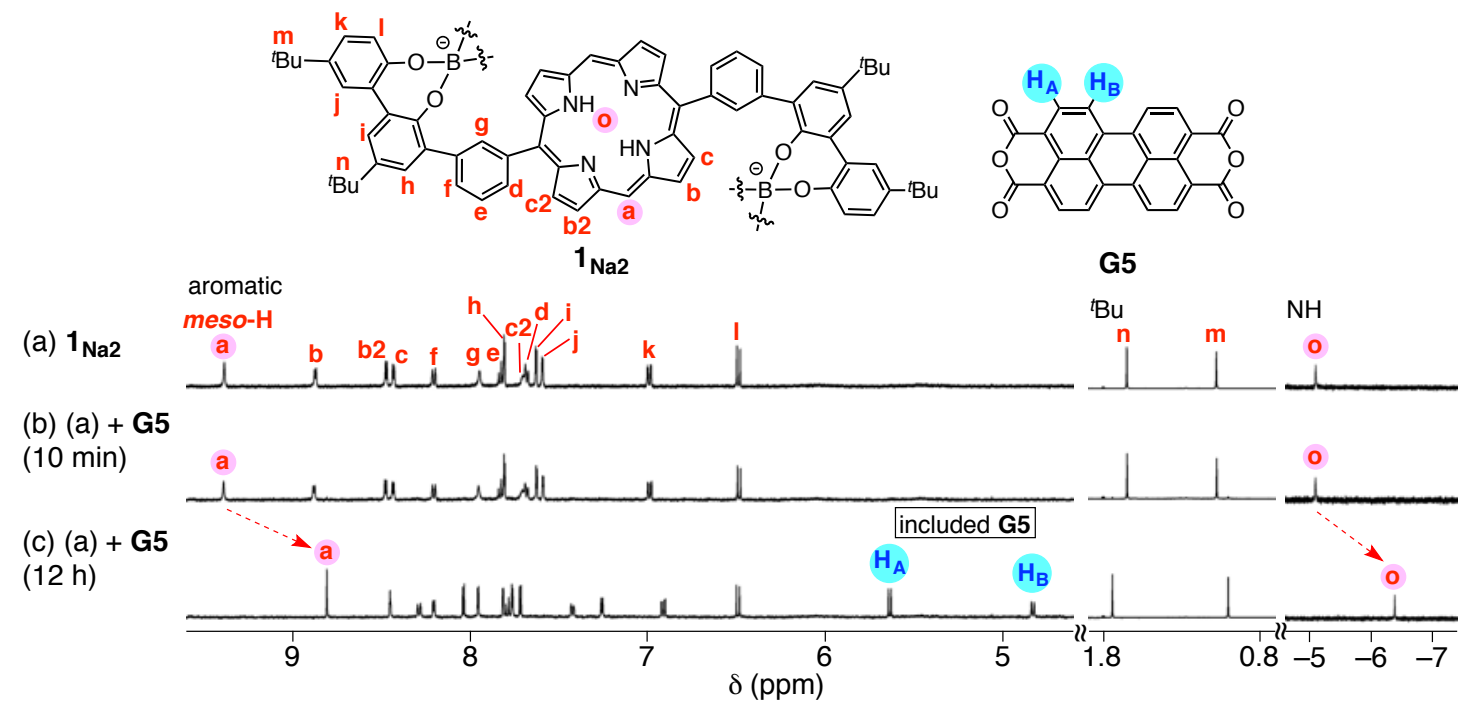

Figure S8. Partial ${ }^{1} \mathrm{H}$ NMR spectra $\left(500 \mathrm{MHz}, \mathrm{CD}_{3} \mathrm{CN}, 25^{\circ} \mathrm{C}\right)$ of $\mathbf{1}_{\mathrm{Na} 2}(0.2 \mathrm{mM})$ in the absence (a) and presence of suspended G5 $[0.13 \mathrm{mg}(0.33 \mu \mathrm{mol})]$ after mixing with a vibrator for $10 \mathrm{~min}$ (b) and $12 \mathrm{~h} \mathrm{(c)} \mathrm{at} \mathrm{ambient} \mathrm{temperature.} \mathrm{G5} \mathrm{is} \mathrm{hardly} \mathrm{soluble} \mathrm{in} \mathrm{CD}_{3} \mathrm{CN}$ and $\mathrm{CDCl}_{3}$, but became soluble in the presence of $\mathbf{1}_{\mathbf{N a} 2}$ to quantitatively form a $1: 1$ inclusion complex after $12 \mathrm{~h}$ (c); $\left[\mathbf{1}_{\mathrm{Na} 2}\right] /\left[\mathbf{1}_{\mathrm{Na} 2} \supset \mathbf{G 5}\right]=95 / 5$ (b) and ca. 0/100 (c) $(\mathrm{mol} / \mathrm{mol})$.
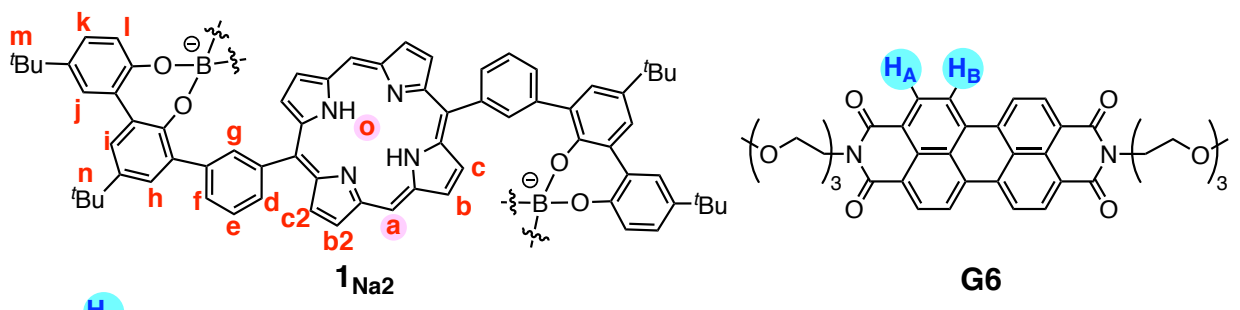

(a) $\mathbf{G 6}$
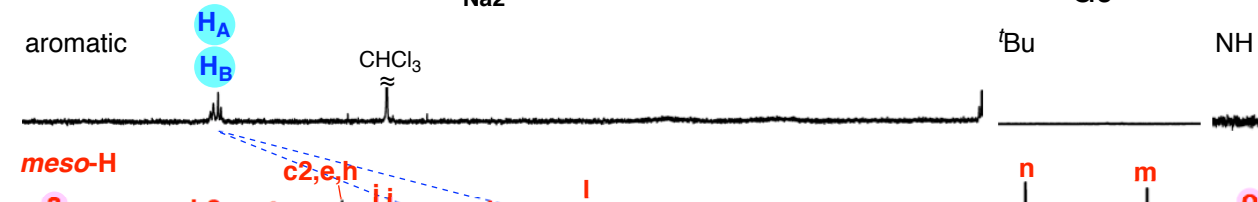

(b) $\mathbf{1}_{\mathrm{Na} 2}$
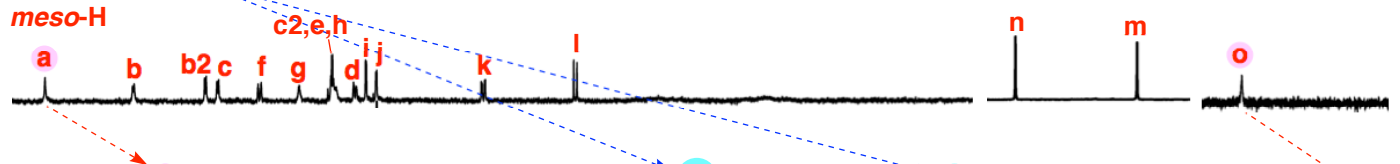

(c) (b) $+\mathbf{G 6}$

(0.5 equiv)

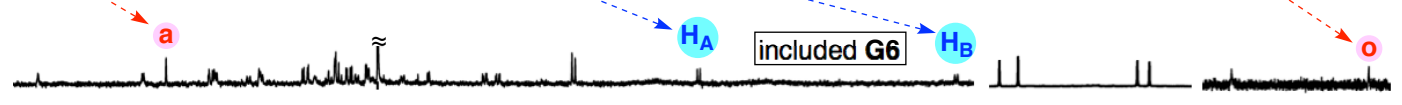

(d) (b) + G6

(1.0 equiv)
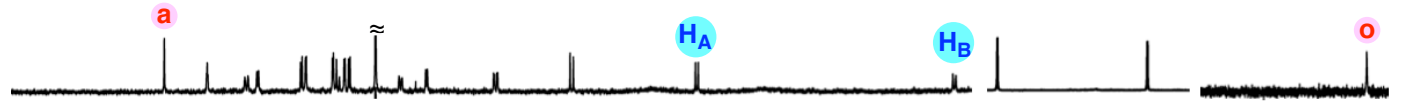

(e) (b) + G6

(2.0 equiv)

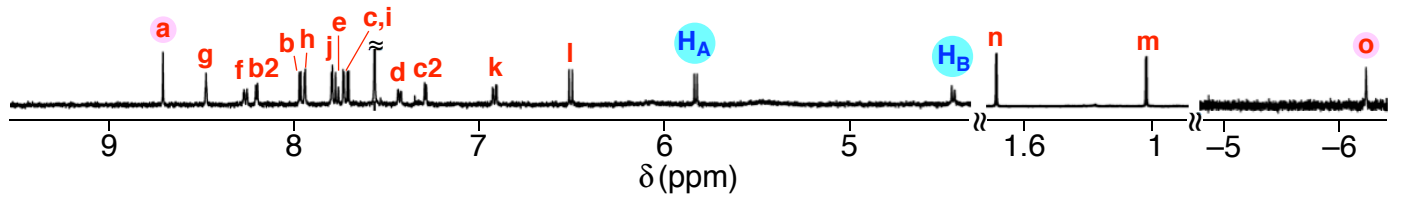

Figure S9. Partial ${ }^{1} \mathrm{H}$ NMR spectra $\left(500 \mathrm{MHz}, 25^{\circ} \mathrm{C}\right)$ of $\mathbf{G 6}\left(0.1 \mathrm{mM}\right.$ in $\mathrm{CD}_{3} \mathrm{CN} / \mathrm{CDCl}_{3}(5 / 2$, v/v)) (a), $\mathbf{1}_{\mathrm{Na} 2}\left(0.1 \mathrm{mM}\right.$ in $\left.\mathrm{CD}_{3} \mathrm{CN}\right)(\mathrm{b})$, and $\mathbf{1}_{\mathrm{Na} 2}$ in the presence of $0.5-2.0$ equiv of $\mathbf{G 6}$ (c-e) in $\mathrm{CD}_{3} \mathrm{CN} / \mathrm{CDCl}_{3}\left(5 / 2\right.$, v/v). $\mathrm{CDCl}_{3}$ was used because $\mathbf{G 6}$ was hardly soluble in $\mathrm{CD}_{3} \mathrm{CN}$. 

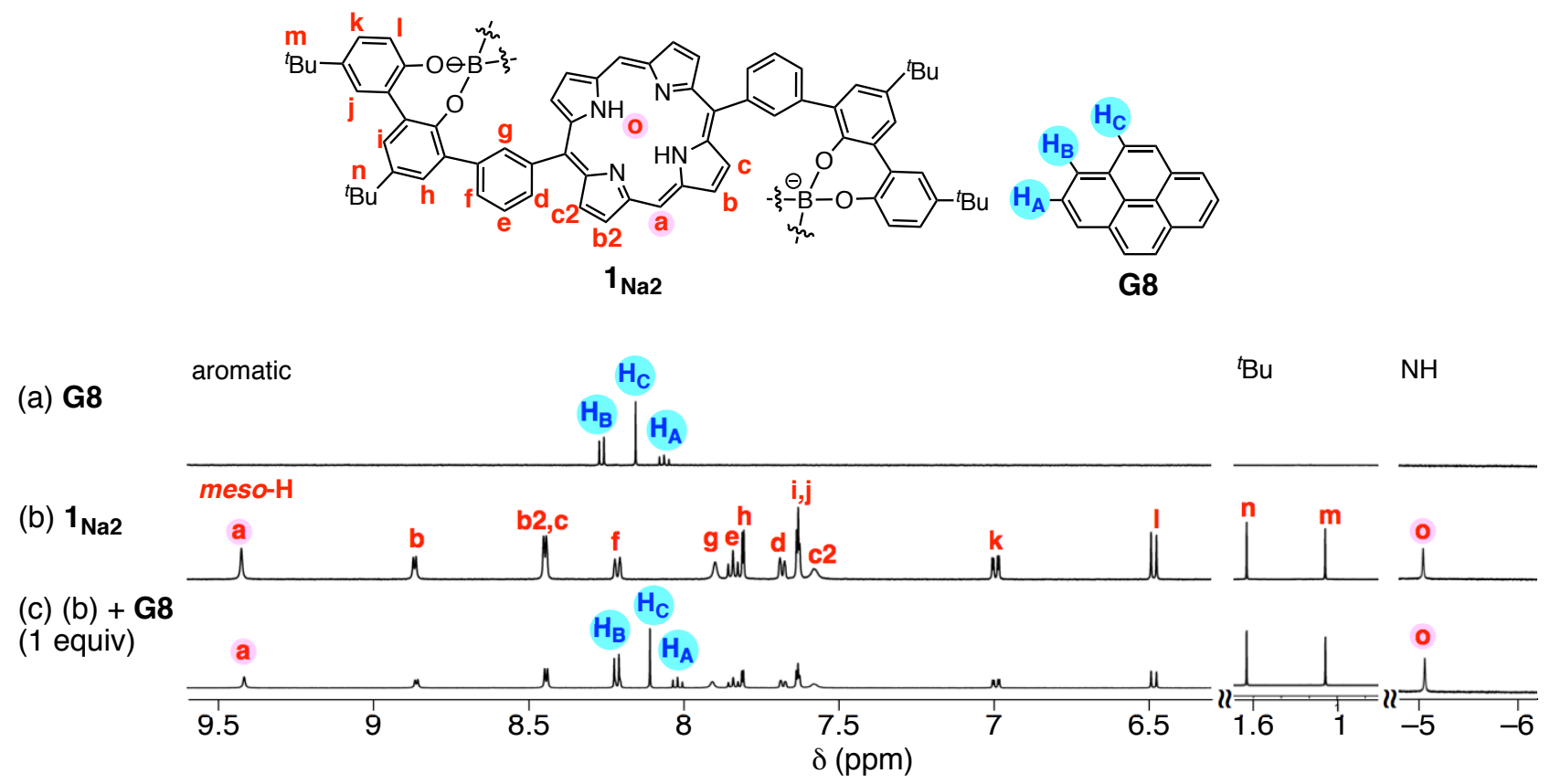

Figure S10. Partial ${ }^{1} \mathrm{H}$ NMR spectra $\left(500 \mathrm{MHz}, \mathrm{CD}_{3} \mathrm{CN}, 25^{\circ} \mathrm{C}\right)$ of $\mathbf{G 8}(0.5 \mathrm{mM})(\mathrm{a}), \mathbf{1}_{\mathrm{Na} 2}(0.5 \mathrm{mM})$ (b), and (b) +1.0 equiv of $\mathbf{G 8}$ (c).
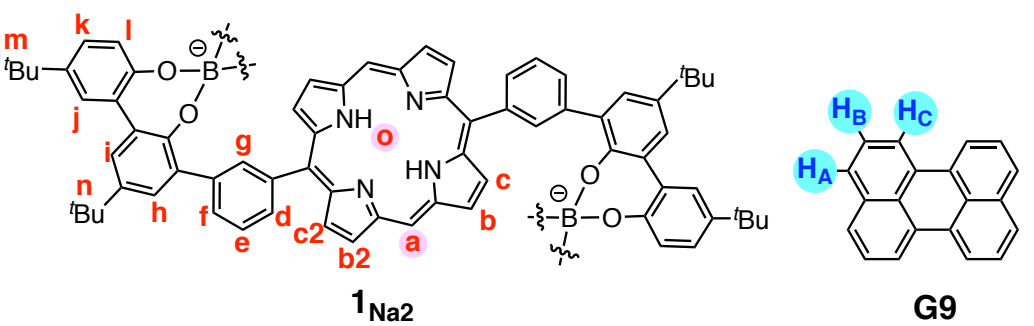

(a) G9

aromatic

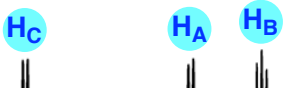

${ }^{t} \mathrm{Bu}$

$\mathrm{NH}$

(b) $\mathbf{1}_{\mathrm{Na} 2}$

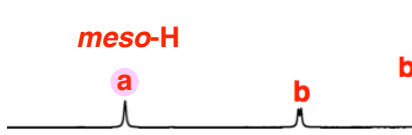

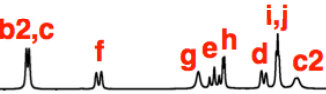
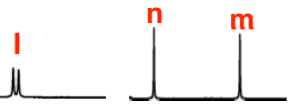

$\stackrel{\circ}{\Lambda}$

(c) (b) + G9

(1 equiv)
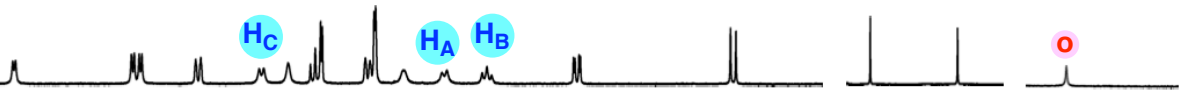

(d) (b) + G9

(10 equiv)

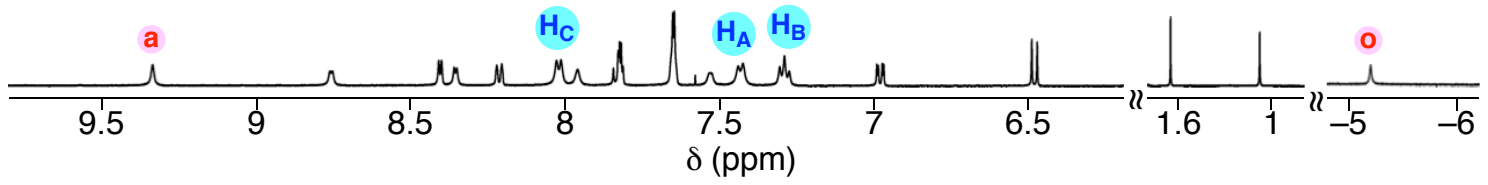

Figure S11. Partial ${ }^{1} \mathrm{H}$ NMR spectra $\left(500 \mathrm{MHz}, \mathrm{CD}_{3} \mathrm{CN}, 25^{\circ} \mathrm{C}\right)$ of $\mathbf{G 9}(0.5 \mathrm{mM})(\mathrm{a}), \mathbf{1}_{\mathrm{Na} 2}(0.5 \mathrm{mM})$ (b), (b) + 1.0 equiv of $\mathbf{G 9}$ (c), and (b) + 10 equiv of G9. 


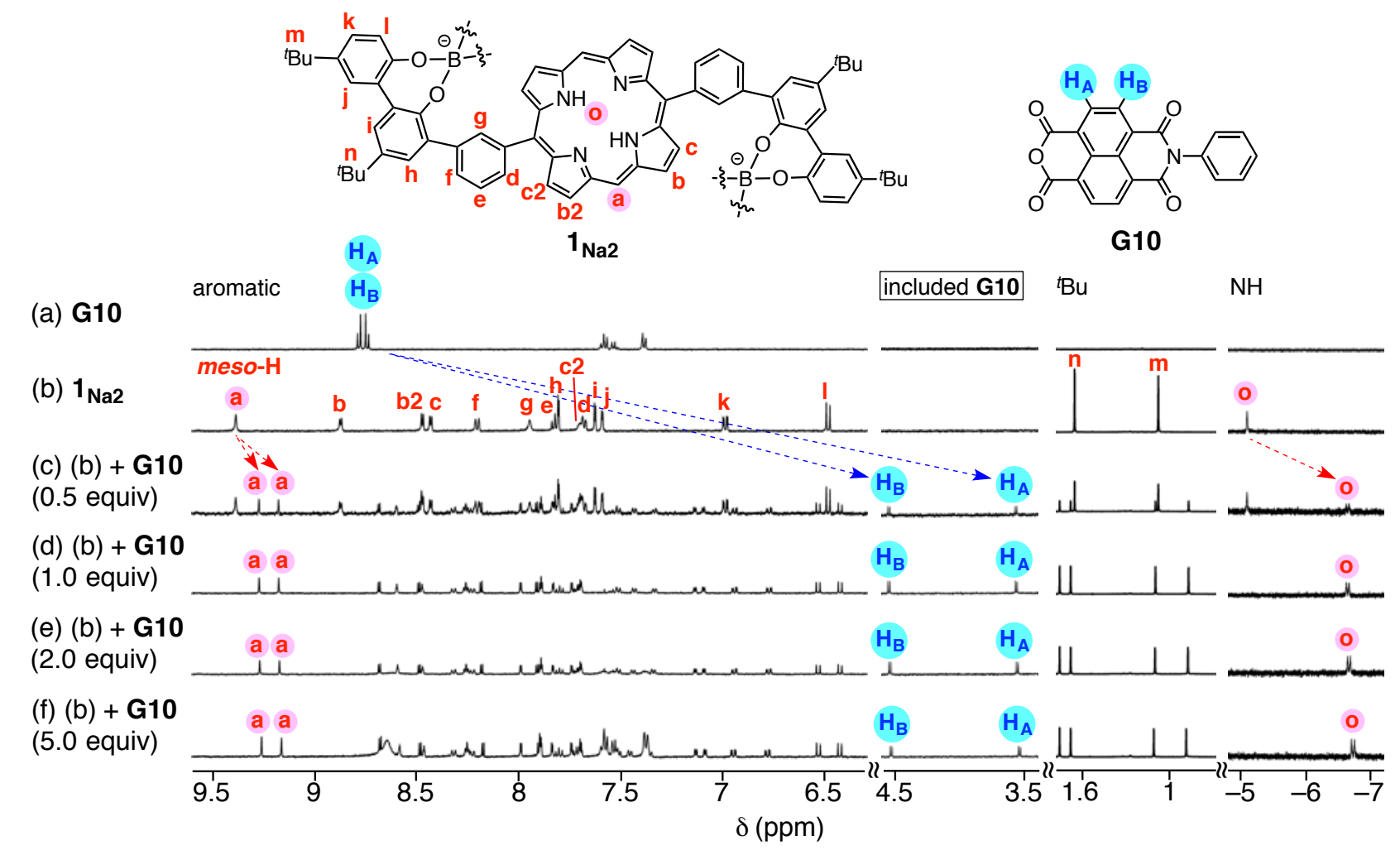

Figure S12. Partial ${ }^{1} \mathrm{H}$ NMR spectra $\left(500 \mathrm{MHz}, \mathrm{CD}_{3} \mathrm{CN}, 25{ }^{\circ} \mathrm{C}\right)$ of $\mathbf{G 1 0}(0.2 \mathrm{mM})(\mathrm{a}), \mathbf{1}_{\mathrm{Na} 2}(0.2$ $\mathrm{mM})(\mathrm{b})$, and (b) +0.5 (c), $1.0(\mathrm{~d}), 2.0$ (e), and 5.0 equiv of $\mathbf{G 1 0}(\mathrm{f})$.

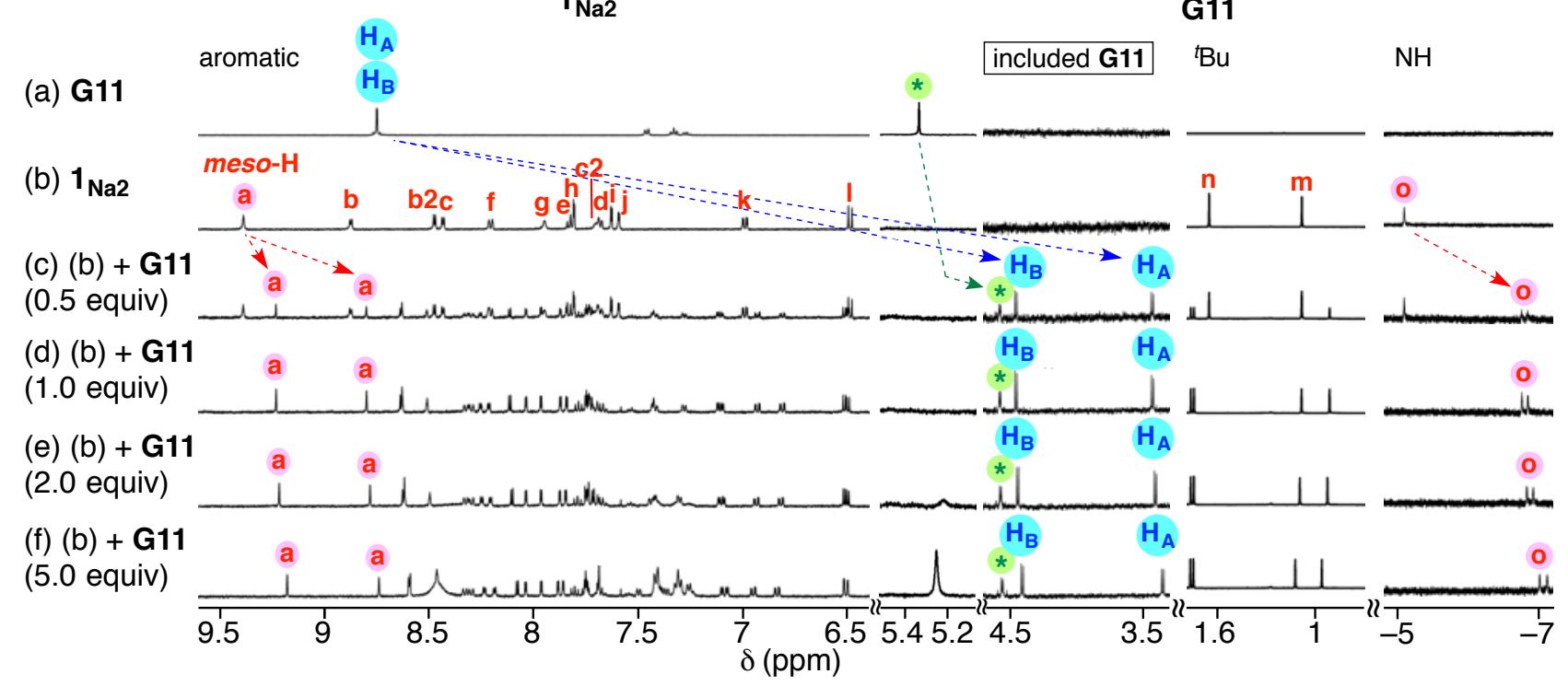

Figure S13. Partial ${ }^{1} \mathrm{H}$ NMR spectra $\left(500 \mathrm{MHz}, \mathrm{CD}_{3} \mathrm{CN}, 25{ }^{\circ} \mathrm{C}\right)$ of $\mathbf{G 1 1}(0.2 \mathrm{mM})(\mathrm{a}), \mathbf{1}_{\mathrm{Na} 2}(0.2$ $\mathrm{mM})(\mathrm{b})$, and (b) + 0.5 (c), 1.0 (d), 2.0 (e), and 5.0 equiv of $\mathbf{G 1 1}(\mathrm{f})$. 


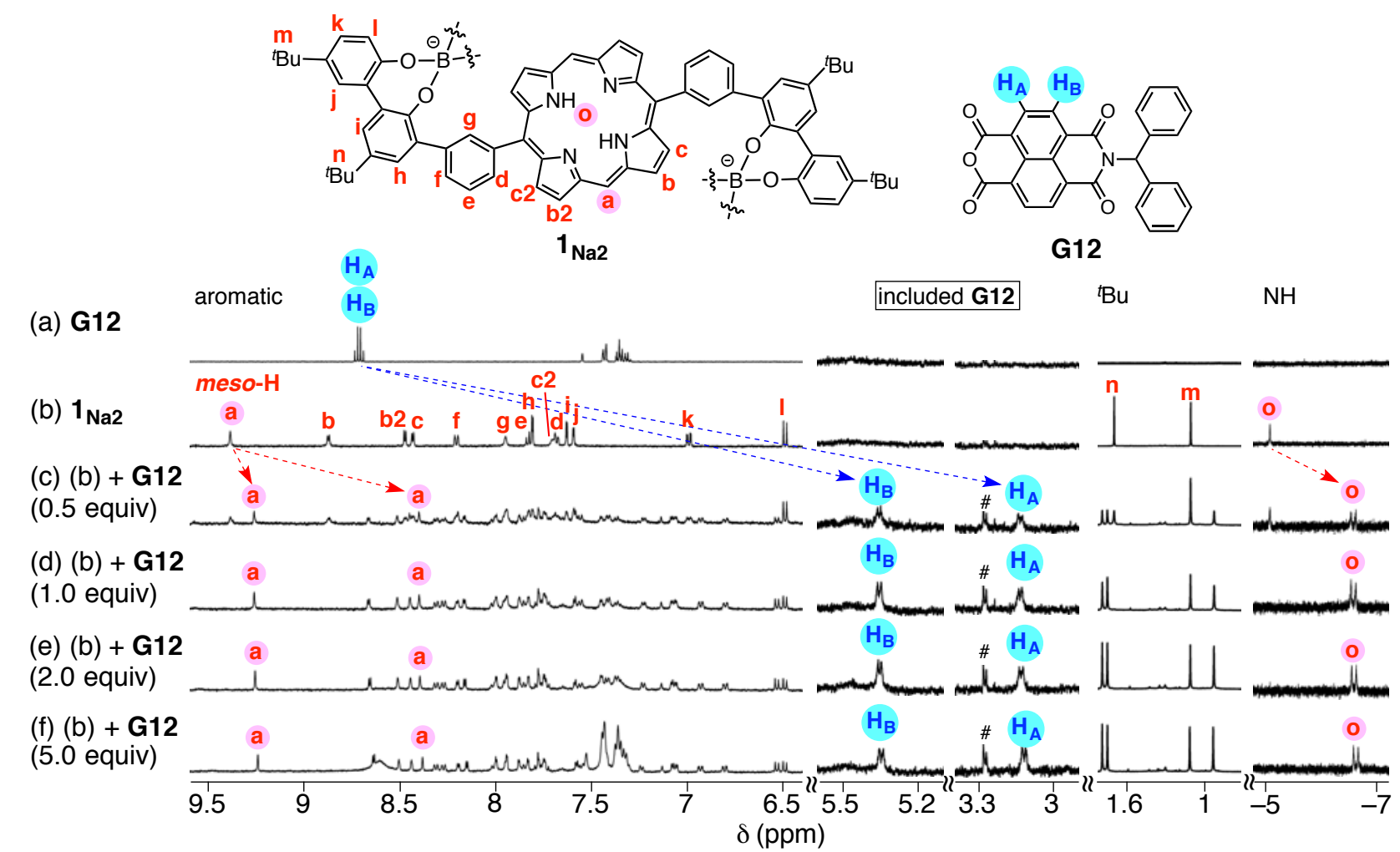

Figure S14. Partial ${ }^{1} \mathrm{H}$ NMR spectra $\left(500 \mathrm{MHz}, \mathrm{CD}_{3} \mathrm{CN}, 25{ }^{\circ} \mathrm{C}\right)$ of $\mathbf{G 1 2}(0.2 \mathrm{mM})$ (a), $\mathbf{1}_{\mathrm{Na} 2}(0.2$ $\mathrm{mM}$ ) (b), and (b) + 0.5 (c), 1.0 (d), 2.0 (e), and 5.0 equiv of $\mathbf{G 1 2}$ (f). \# denotes impurities contained in the solvent $\mathrm{CD}_{3} \mathrm{CN}$.

(a) $\mathbf{G 1 3}$
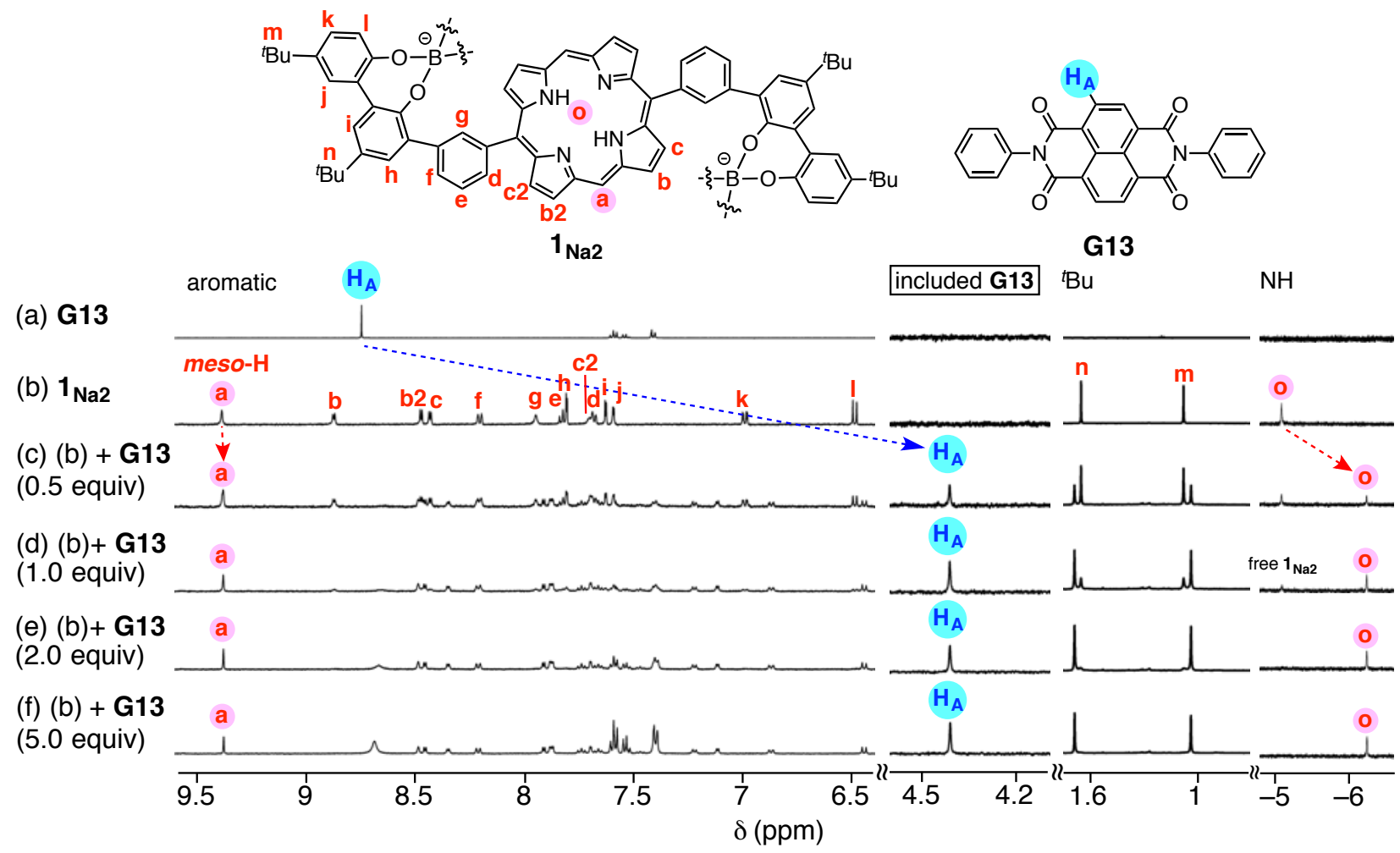

Figure S15. Partial ${ }^{1} \mathrm{H}$ NMR spectra $\left(500 \mathrm{MHz}, \mathrm{CD}_{3} \mathrm{CN}, 25^{\circ} \mathrm{C}\right)$ of $\mathbf{G 1 3}(0.2 \mathrm{mM})(\mathrm{a}), \mathbf{1}_{\mathrm{Na} 2}(0.2$ $\mathrm{mM}$ ) (b), and (b) + 0.5 (c), 1.0 (d), 2.0 (e), and 5.0 equiv of $\mathbf{G 1 3}$ (f). 


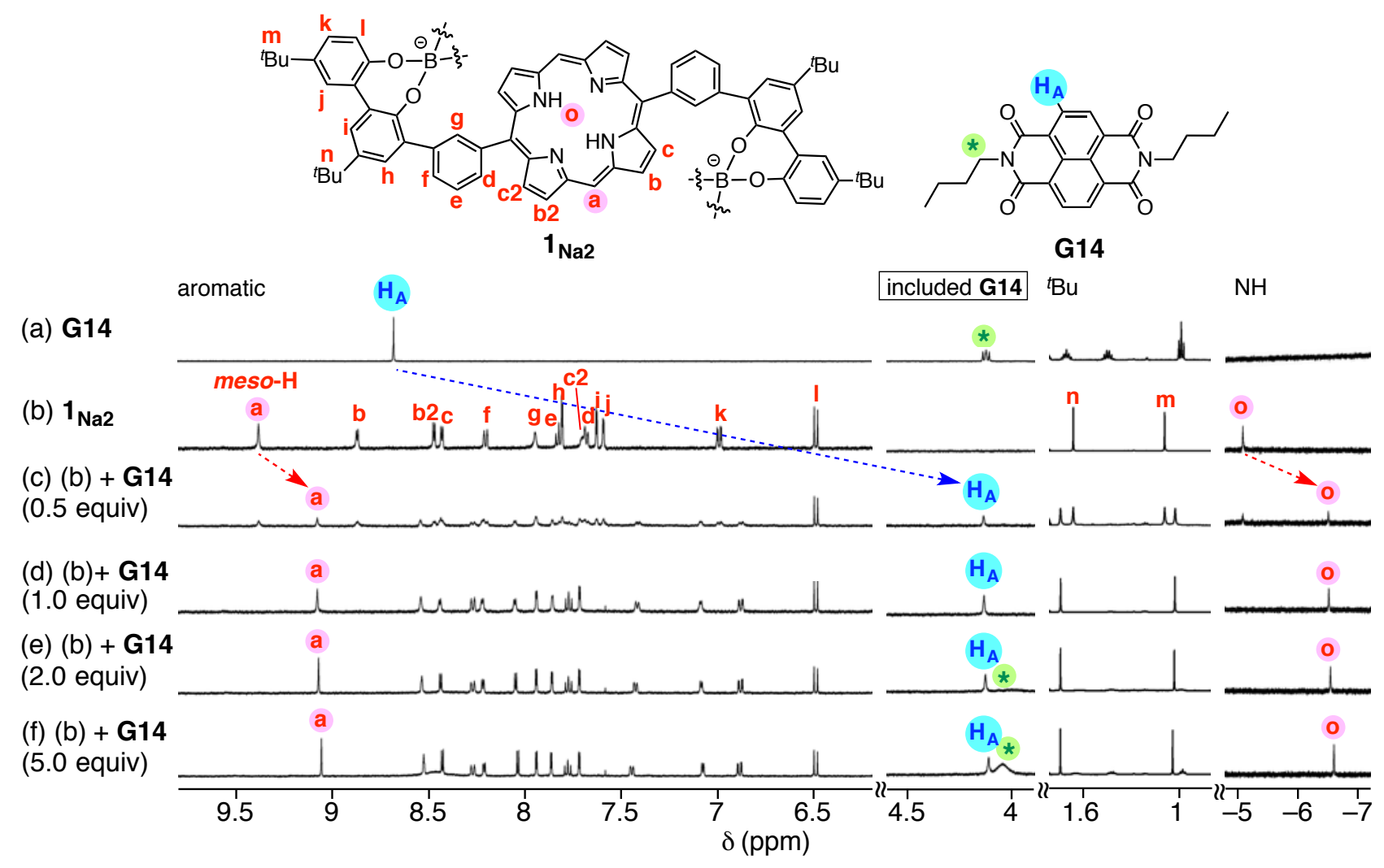

Figure S16. Partial ${ }^{1} \mathrm{H}$ NMR spectra $\left(500 \mathrm{MHz}, \mathrm{CD}_{3} \mathrm{CN}, 25{ }^{\circ} \mathrm{C}\right)$ of $\mathbf{G 1 4}(0.2 \mathrm{mM})(\mathrm{a}), \mathbf{1}_{\mathrm{Na} 2}(0.2$ $\mathrm{mM})(\mathrm{b})$, and (b) +0.5 (c), 1.0 (d), 2.0 (e), and 5.0 equiv of $\mathbf{G 1 4}$ (f).
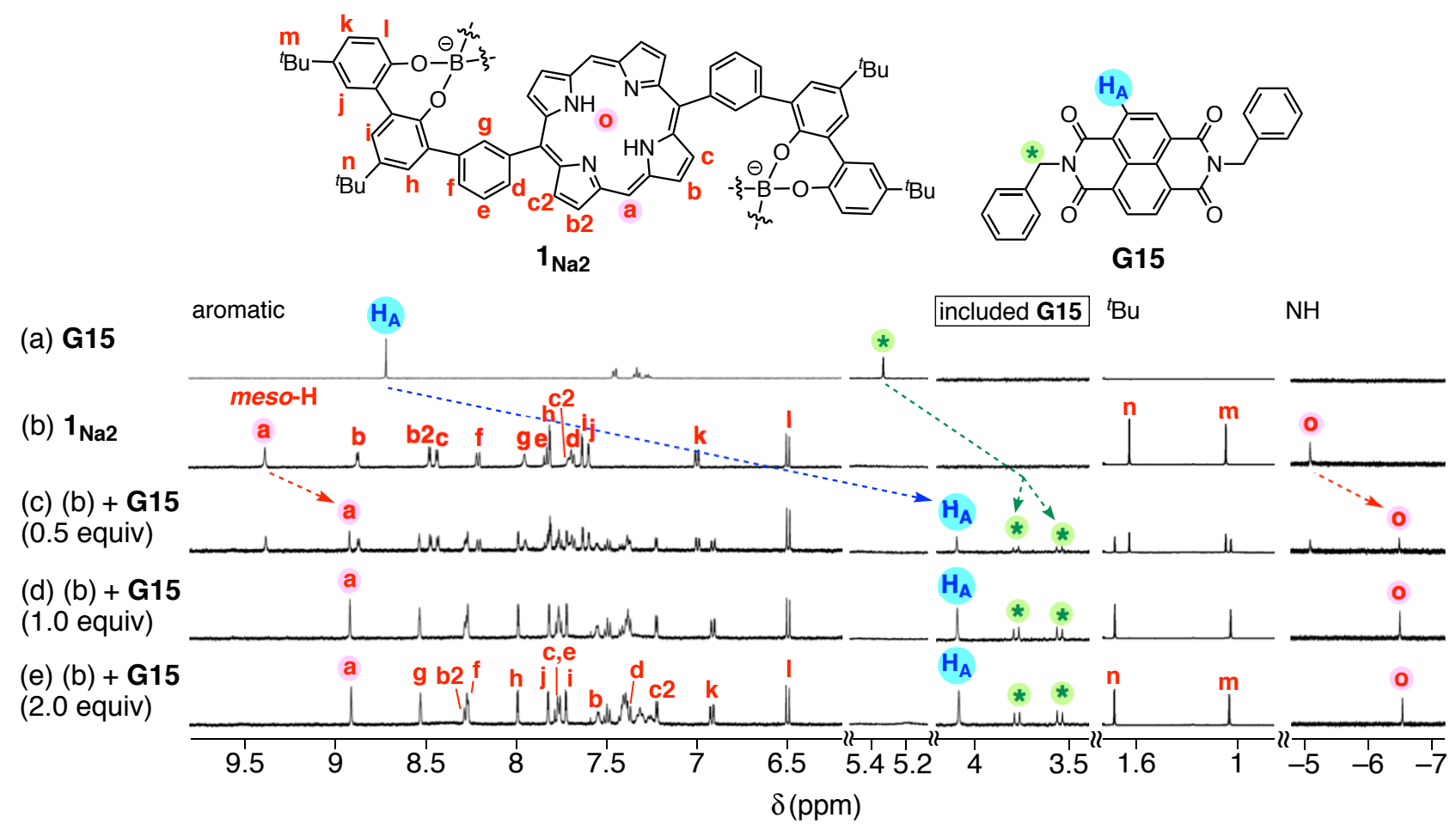

Figure S17. Partial ${ }^{1} \mathrm{H}$ NMR spectra $\left(500 \mathrm{MHz}, \mathrm{CD}_{3} \mathrm{CN}, 25{ }^{\circ} \mathrm{C}\right)$ of $\mathbf{G 1 5}(0.2 \mathrm{mM})(\mathrm{a}), \mathbf{1}_{\mathrm{Na} 2}(0.2$ $\mathrm{mM})(\mathrm{b})$, and (b) $+0.5(\mathrm{c}), 1.0(\mathrm{~d})$, and 2.0 equiv of $\mathbf{G 1 5}(\mathrm{e})$. 

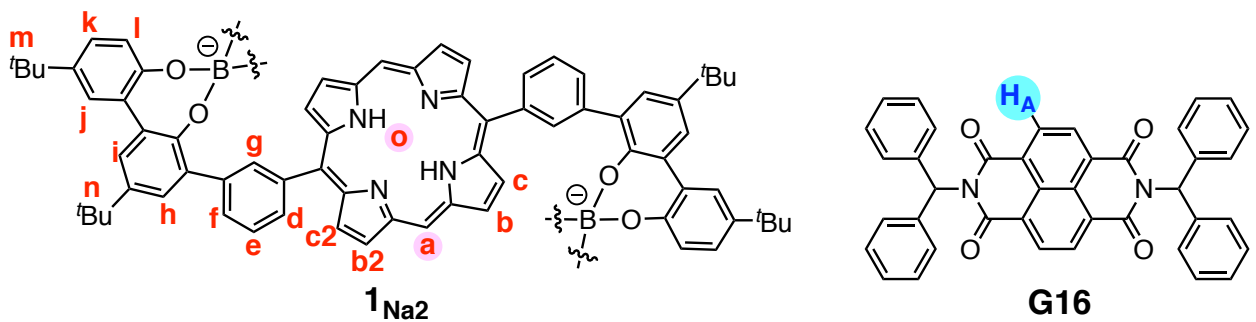

(a) G16

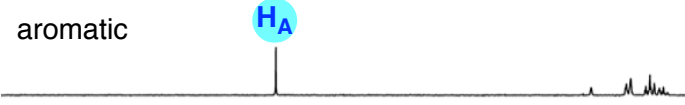

${ }^{t} \mathrm{Bu}$

$\mathrm{NH}$

(b) $\mathbf{1}_{\mathrm{Na} 2}$
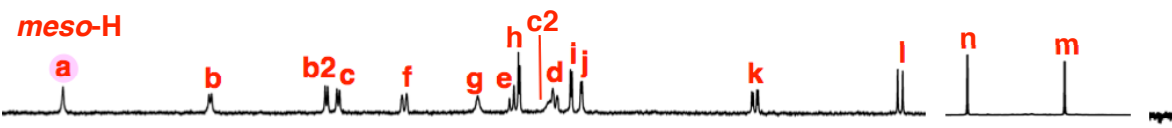

(c) (b) + G16

(d) (b) + G16

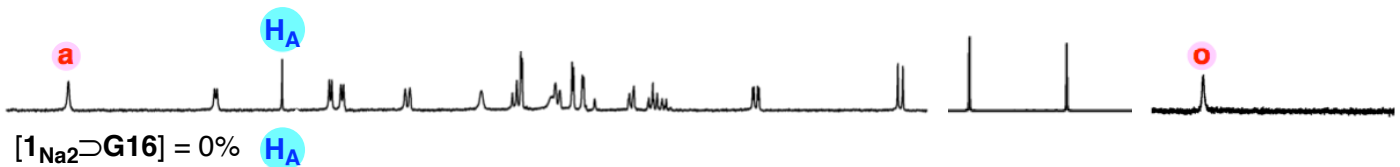

$\left(80^{\circ} \mathrm{C}\right.$, for one

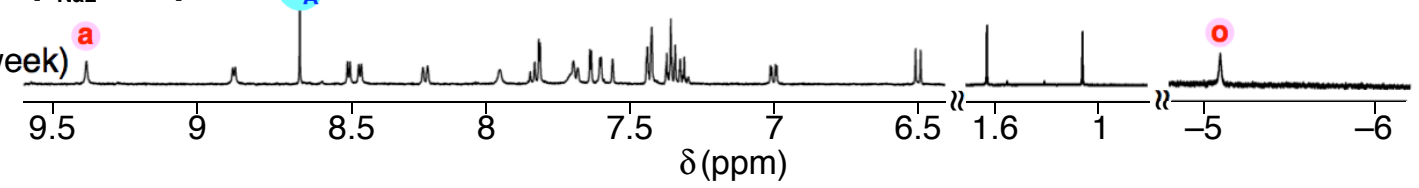

Figure S18. Partial ${ }^{1} \mathrm{H}$ NMR spectra $\left(500 \mathrm{MHz}, \mathrm{CD}_{3} \mathrm{CN}, 25^{\circ} \mathrm{C}\right)$ of $\mathbf{G 1 6}(0.2 \mathrm{mM})$ (a) and $\mathbf{1}_{\mathrm{Na} 2}(0.2$ $\mathrm{mM}$ ) in the absence (b) and presence of 1 equiv of $\mathbf{G 1 6}$ before (c) and after heating at $80{ }^{\circ} \mathrm{C}$ for one week (d). $\left[\mathrm{H}_{2} \mathrm{O}\right] /\left[\mathbf{1}_{\mathrm{Na} 2}\right]=$ ca. 150 .
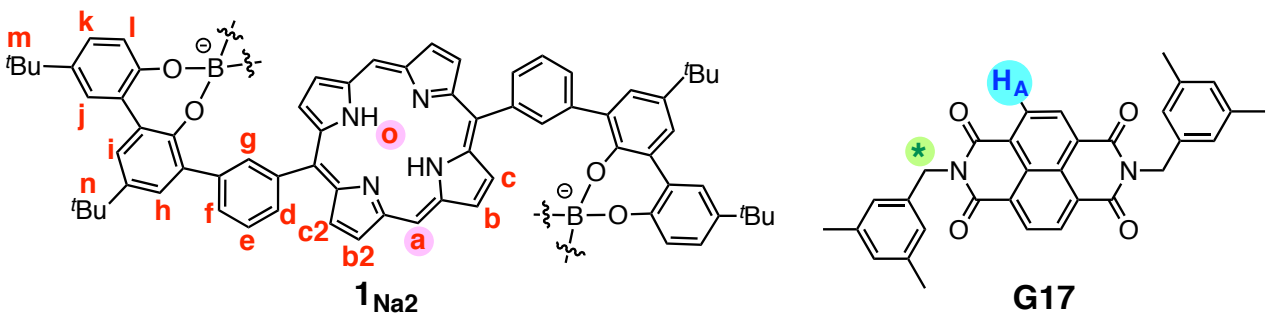

(a) $1_{\mathrm{Na} 2}$ meso-H

(b) (a) + G17

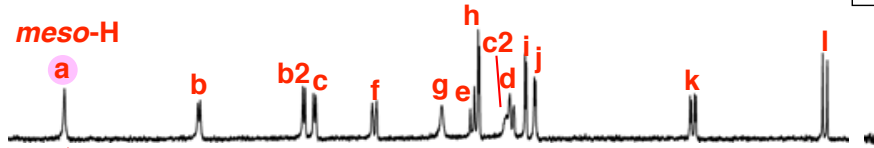

included G17 t $\mathrm{Bu}$

$\mathrm{NH}$

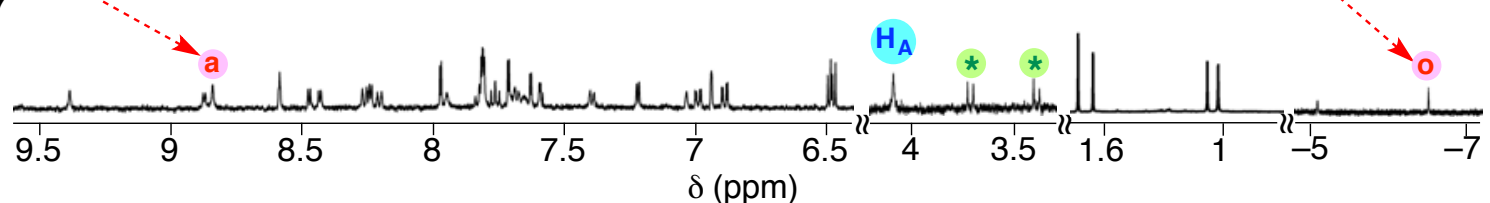

Figure S19. Partial ${ }^{1} \mathrm{H}$ NMR spectra $\left(500 \mathrm{MHz}, \mathrm{CD}_{3} \mathrm{CN}, 25^{\circ} \mathrm{C}\right)$ of $\mathbf{1}_{\mathrm{Na} 2}(0.2 \mathrm{mM})$ in the absence (a) and presence of suspended G17 $[0.35 \mathrm{mg}(0.70 \mu \mathrm{mol})]$ after mixing with a vibrator until reaching an equilibrium state $\left(\left[\mathbf{1}_{\mathrm{Na} 2}\right] /\left[\mathbf{1}_{\mathrm{Na} 2} \supset \mathbf{G 1 7}\right]=43 / 57(\mathrm{~mol} / \mathrm{mol})\right)(\mathrm{b})$. 
(a) G18
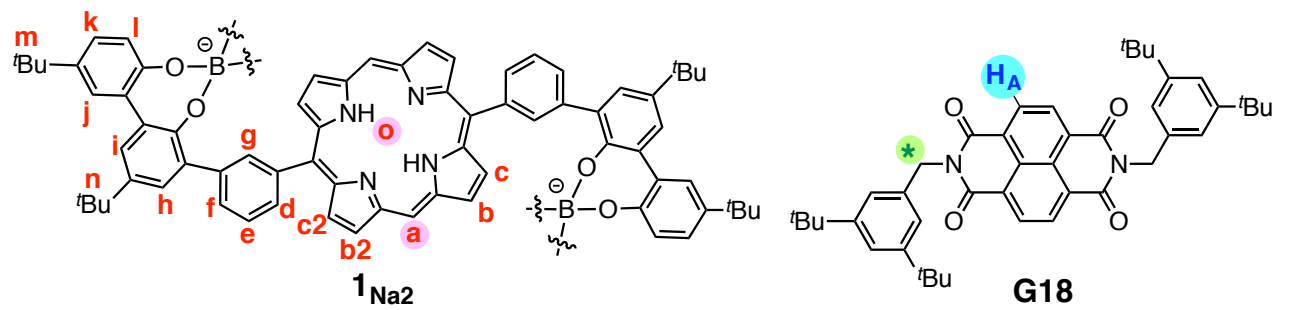

asonete

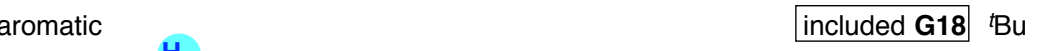

$\mathrm{NH}$

(b) $\mathbf{1}_{\mathrm{Na} 2}$

(c) (b) + G18

(d) (b) + G18

(80 ${ }^{\circ} \mathrm{C}$, for one week)

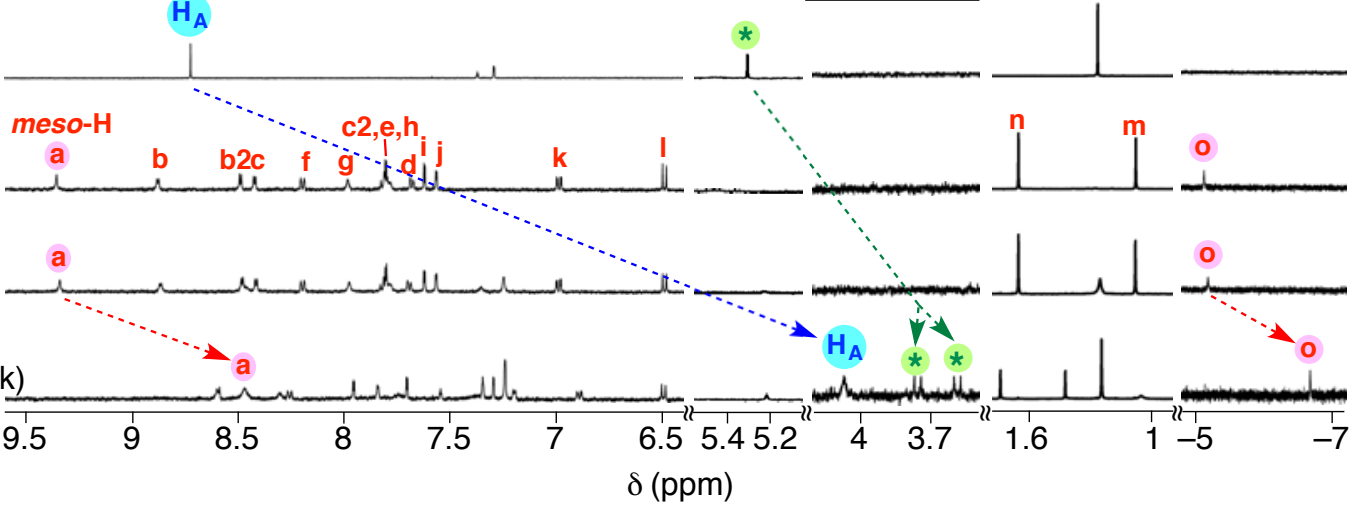

Figure S20. Partial ${ }^{1} \mathrm{H}$ NMR spectra $\left(500 \mathrm{MHz}, \mathrm{CD}_{3} \mathrm{CN}, 25{ }^{\circ} \mathrm{C}\right)$ of $\mathbf{G 1 8}(0.1 \mathrm{mM})(\mathrm{a}), \mathbf{1}_{\mathrm{Na} 2}(0.1$ $\mathrm{mM})(\mathrm{b})$, and a 1:1 mixture of $\mathbf{G 1 8}(0.1 \mathrm{mM})$ and $\mathbf{1}_{\mathrm{Na} 2}(0.1 \mathrm{mM})$ measured at $25^{\circ} \mathrm{C}$ before (c) and after heating at $80{ }^{\circ} \mathrm{C}$ for one week $(d) .\left[\mathrm{H}_{2} \mathrm{O}\right] /\left[\mathbf{1}_{\mathrm{Na} 2}\right]=$ ca. 220 .
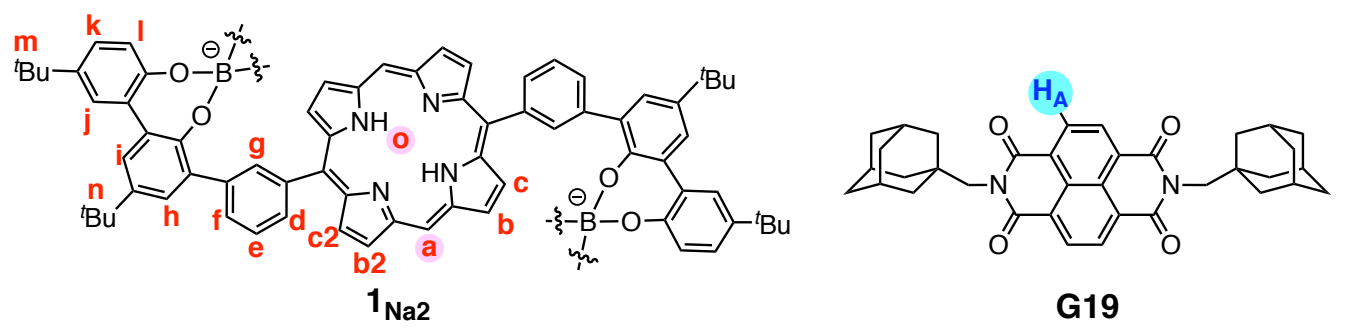

(a) G19
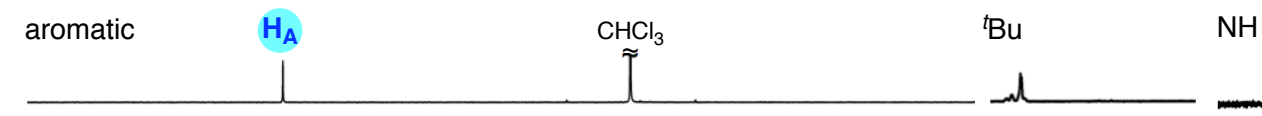

(b) $\mathbf{1}_{\mathrm{Na} 2}$

meso-H

(c) (b) + G19
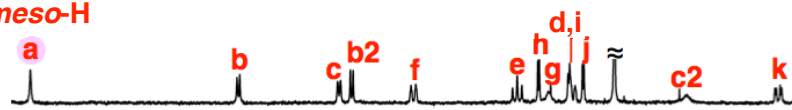

$-d$

$\mathrm{NH}$

(d) (b) + G19

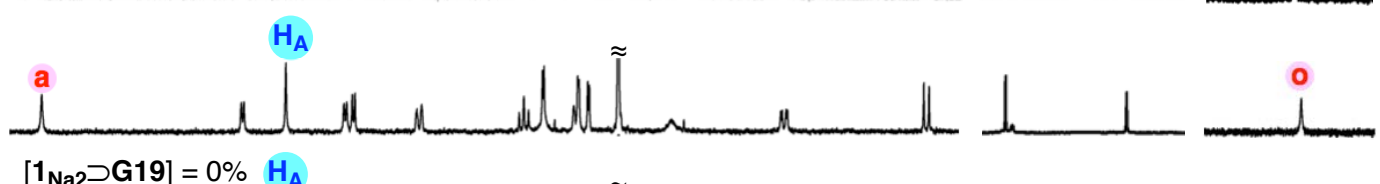

$\left[\mathbf{1}_{\mathrm{Na2}} \supset \mathbf{G 1 9}\right]=0 \% \quad \mathrm{H}_{\mathrm{A}}$

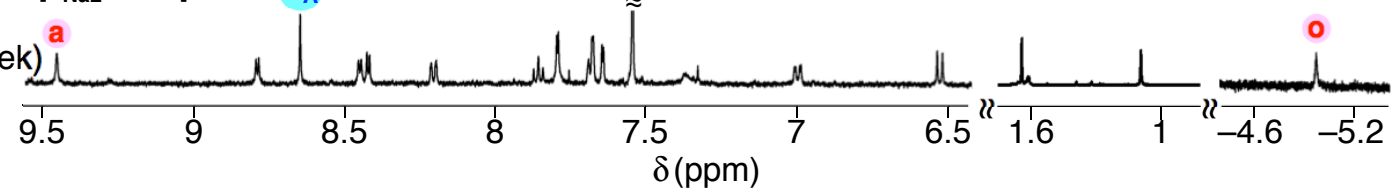

Figure S21. Partial ${ }^{1} \mathrm{H}$ NMR spectra $\left(500 \mathrm{MHz}, \mathrm{CD}_{3} \mathrm{CN} / \mathrm{CDCl}_{3}(5 / 2, \mathrm{v} / \mathrm{v}), 25^{\circ} \mathrm{C}\right)$ of $\mathbf{G 1 9}(0.1 \mathrm{mM})$ (a), $\mathbf{1}_{\mathrm{Na} 2}(0.1 \mathrm{mM})(\mathrm{b})$, and a 1:1 mixture of $\mathbf{G 1 9}(0.1 \mathrm{mM})$ and $\mathbf{1}_{\mathrm{Na} 2}$ measured at $25^{\circ} \mathrm{C}$ before (c) and after heating at $80{ }^{\circ} \mathrm{C}$ for one week $(d) .\left[\mathrm{H}_{2} \mathrm{O}\right] /\left[\mathbf{1}_{\mathrm{Na} 2}\right]=\mathrm{ca} .225$. 


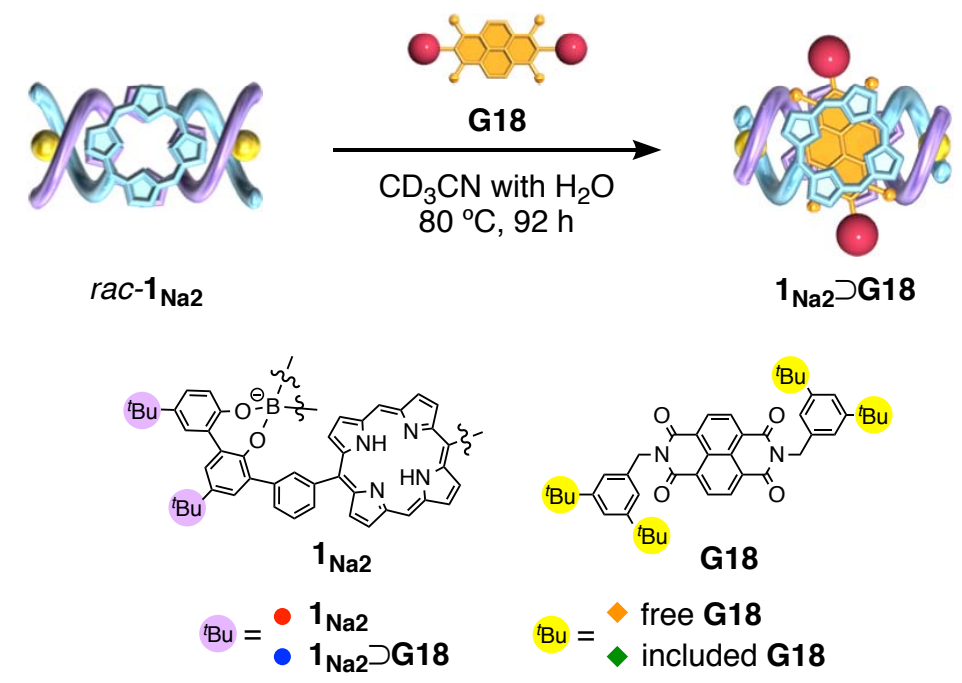

$\left[\mathrm{H}_{2} \mathrm{O}\right] /\left[\mathbf{1}_{\mathrm{Na} 2}\right]=\mathrm{ca} .<5$

$\left[\mathrm{H}_{2} \mathrm{O}\right] /\left[\mathbf{1}_{\mathrm{Na} 2}\right]=$ ca. 220

(a) $\mathbf{1}_{\mathrm{Na} 2}+\mathrm{G} 18$

(c) $\mathbf{1}_{\mathrm{Na} 2}+\mathrm{G} 18$

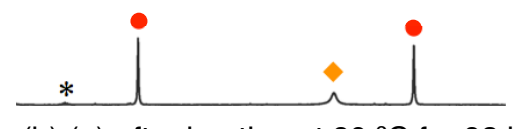

(b) (a) after heating at $80^{\circ} \mathrm{C}$ for $92 \mathrm{~h}$

$\bullet: \bullet=96: 4$

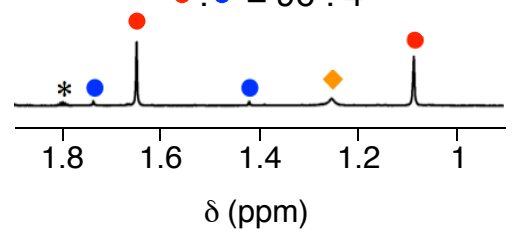

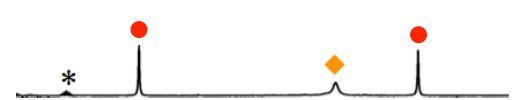

(d) (c) after heating at $80^{\circ} \mathrm{C}$ for $92 \mathrm{~h}$

:• $=32: 68$

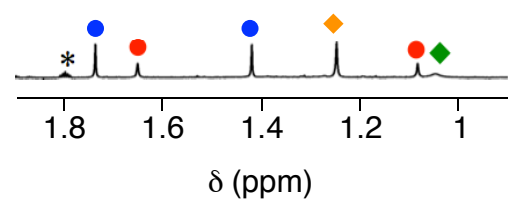

Figure S22. Partial ${ }^{1} \mathrm{H}$ NMR spectra $\left(500 \mathrm{MHz}, \mathrm{CD}_{3} \mathrm{CN}, 0.10 \mathrm{mM}\right.$, ambient temperature) of $\mathbf{1}_{\mathrm{Na} 2}$ in the presence of 1 equiv of $\mathbf{G 1 8}$ before (a, c) and after (b, d) heating at $80{ }^{\circ} \mathrm{C}$ for $92 \mathrm{~h}$ in dry $\mathrm{CH}_{3} \mathrm{CN}$ containing less than $0.001 \%$ of $\mathrm{H}_{2} \mathrm{O}\left(\left[\mathrm{H}_{2} \mathrm{O}\right] /\left[\mathbf{1}_{\mathrm{Na} 2}\right]=\right.$ ca. $\left.<5\right)$ (b) and aqueous $\mathrm{CD}_{3} \mathrm{CN}\left(\left[\mathrm{H}_{2} \mathrm{O}\right] /\left[\mathbf{1}_{\mathrm{Na} 2}\right]\right.$ $=$ ca. 220$)(\mathrm{d}) . *$ denotes the ${ }^{13} \mathrm{C}$ satellite signal of the solvent. 


\section{Kinetic Parameters for the Inclusion of Guest G18 within $\mathbf{1}_{\mathrm{Na} 2}$.}

The second-order rate constants $\left(k, \mathrm{M}^{-1} \mathrm{sec}^{-1}\right)$ for the inclusion complexation between $\mathbf{1}_{\mathrm{Na} 2}$ and G18 were determined by the following equation:

$1 /\left[\mathbf{1}_{\mathrm{Na} 2}\right]_{t}=k t+1 /\left[\mathbf{1}_{\mathrm{Na} 2}\right]_{0}$

where $\left[\mathbf{1}_{\mathrm{Na} 2}\right]_{t}$ and $\left[\mathbf{1}_{\mathrm{Na} 2}\right]_{0}$ are the concentration of $\mathbf{1}_{\mathrm{Na} 2}$ at time $t=t$ and $t=0$, respectively.

The $k$ values for the formation of $\mathbf{1}_{\mathrm{Na} 2} \supset \mathbf{G 1 8}$ from a 1:1 mixture of $\mathbf{1}_{\mathrm{Na} 2}$ and $\mathbf{G 1 8}$ in $\mathrm{CD}_{3} \mathrm{CN}$ containing $\mathrm{H}_{2} \mathrm{O}$ (ca. 220 equiv) at different temperatures $\left(50,60,70\right.$, and $80{ }^{\circ} \mathrm{C}$ ) were estimated from the slope of the linear plots of $1 /\left[\mathbf{1}_{\mathrm{Na} 2}\right]_{t}$ as a function of time (Figure $\mathrm{S} 23 \mathrm{~b}$ ). The reaction progresses at the different temperatures were monitored by ${ }^{1} \mathrm{H}$ NMR spectroscopy (Figure S23a). The kinetic parameters for the inclusion of $\mathbf{G 1 8}$ within $\mathbf{1}_{\mathrm{Na} 2}$ were determined by the Arrhenius and Eyring plots of the data obtained from Figure S23b (Figure S23c,d). 


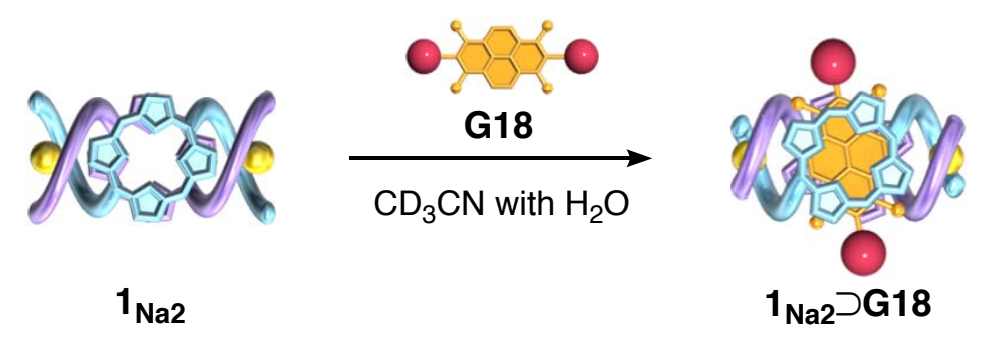

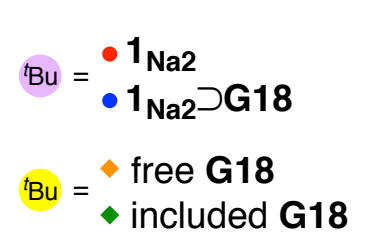

(a)
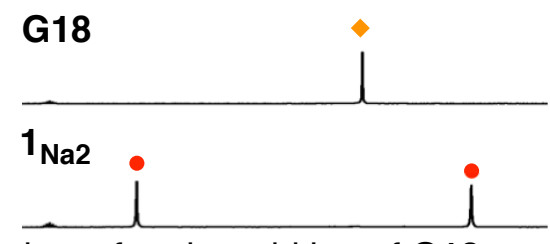

just after the addtion of G18
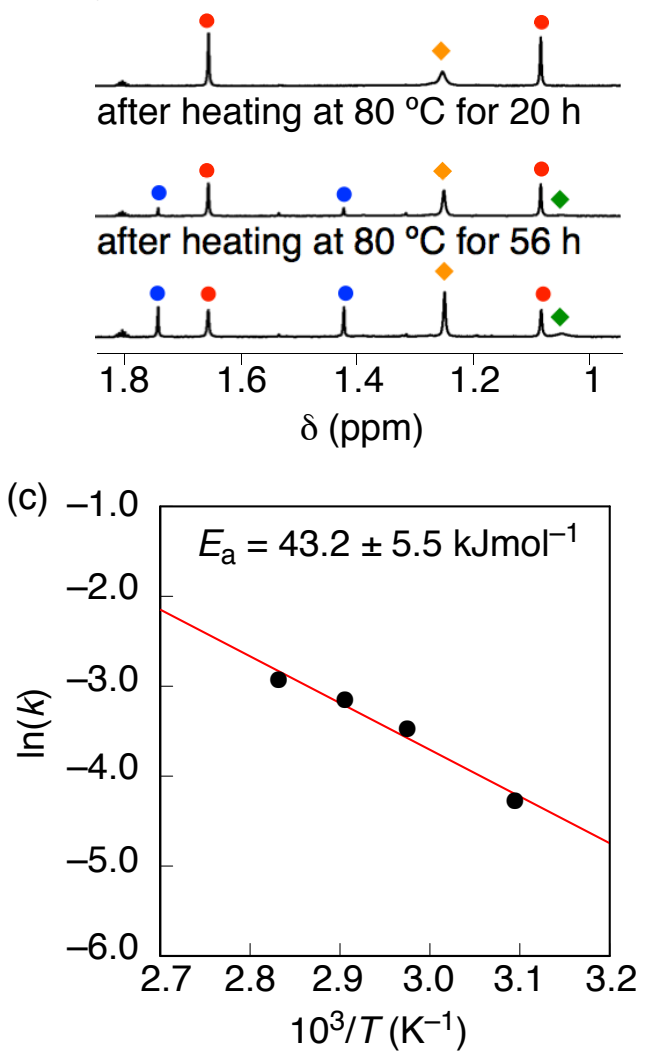

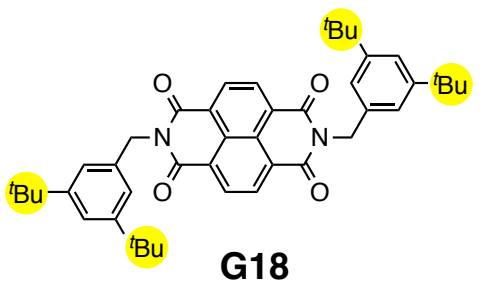

(b)
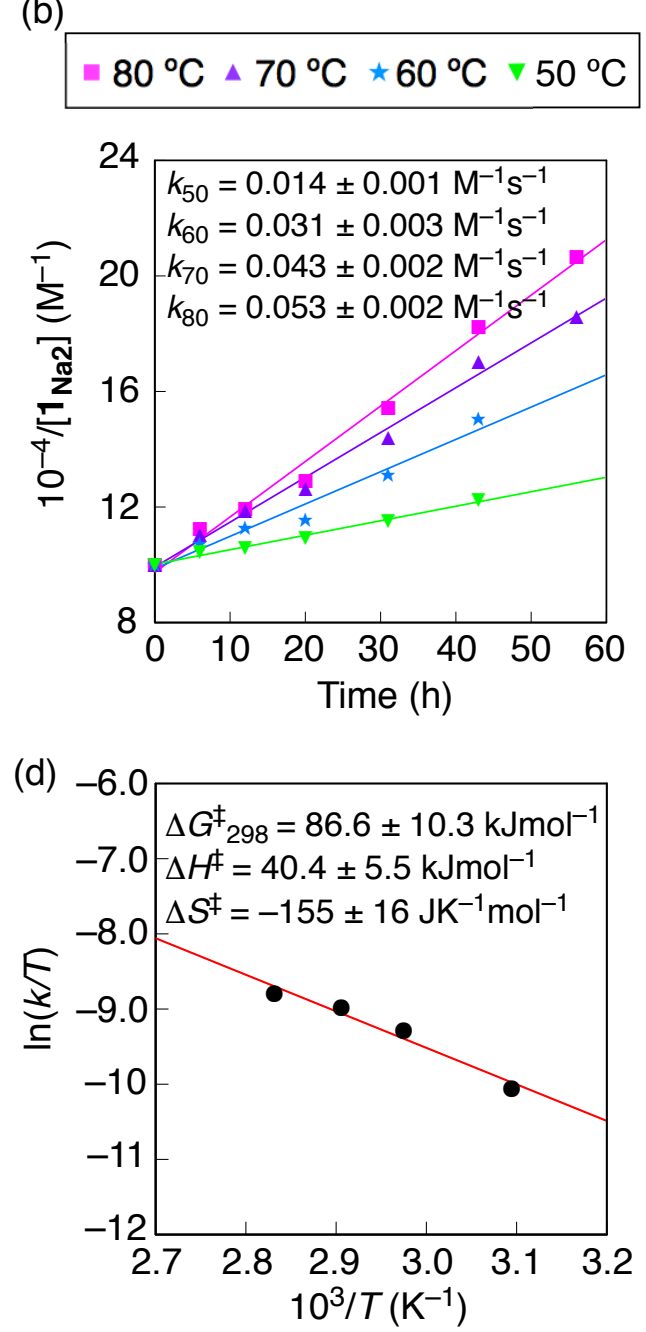

Figure S23. (a) Time-dependent partial ${ }^{1} \mathrm{H}$ NMR spectral changes of an equimolar mixture of $\mathbf{1}_{\mathrm{Na} 2}$ and $\mathbf{G 1 8}$ in $\mathrm{CD}_{3} \mathrm{CN}$ measured at $25^{\circ} \mathrm{C}$ with a small amount of water before and after heating at 80 ${ }^{\circ} \mathrm{C}$ for 20 and $56 \mathrm{~h} .\left[\mathbf{1}_{\mathrm{Na} 2}\right]_{0}=[\mathbf{G 1 8}]_{0}=0.10 \mathrm{mM}$ and $\left[\mathrm{H}_{2} \mathrm{O}\right] /\left[\mathbf{1}_{\mathrm{Na} 2}\right]_{0}=$ ca. 220 . Partial ${ }^{1} \mathrm{H} \mathrm{NMR}$ spectra of $\mathbf{1}_{\mathrm{Na} 2}$ and $\mathbf{G 1 8}$ in $\mathrm{CD}_{3} \mathrm{CN}$ at ambient temperature are also shown. (b) Plots of $1 /\left[\mathbf{1}_{\mathrm{Na} 2}\right]$ as a function of time for the inclusion complexation of $\mathbf{1}_{\mathbf{N a 2}}$ with $\mathbf{G 1 8}$ in $\mathrm{CD}_{3} \mathrm{CN}$ at different temperatures $\left(50,60,70\right.$, and $\left.80{ }^{\circ} \mathrm{C}\right):\left[\mathbf{1}_{\mathrm{Na} 2}\right]_{0}=[\mathbf{G 1 8}]_{0}=0.10 \mathrm{mM}$. (c, d) Arrhenius (c) and Eyring (d) plots for the inclusion complexation of $\mathbf{1}_{\mathrm{Na} 2}$ with $\mathbf{G 1 8}$ in $\mathrm{CD}_{3} \mathrm{CN}$. 


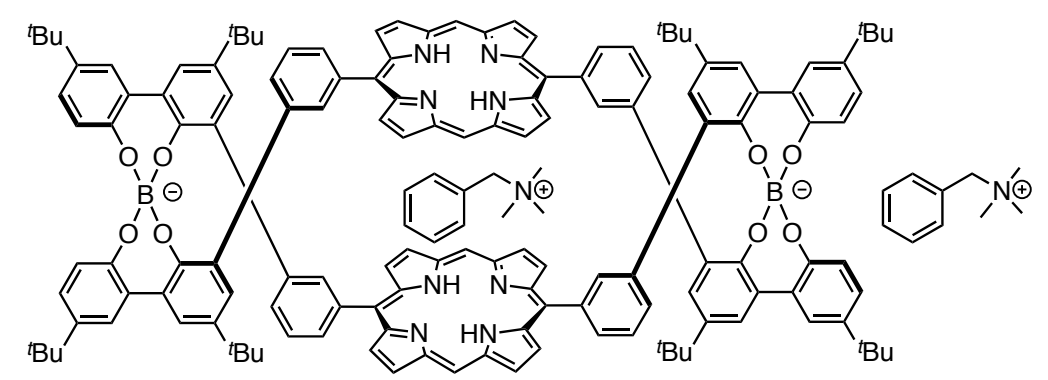

\section{Crystallographic Data of $1_{\text {BTMA2 }}$}

X-ray diffraction data set for $\mathbf{1}_{\text {BTMA2 }}$ (BTMA = benzyltrimethylammonium) was collected on a Rigaku Saturn 724+ CCD diffractometer with Mo Ka radiation $(l=0.71075 \AA)$ at $113 \mathrm{~K}$. Single crystals of $\mathbf{1}_{\mathbf{B T M A 2}}$ [ $\mathrm{C}_{191} \mathrm{H}_{218} \mathrm{~B}_{2} \mathrm{~N}_{10} \mathrm{O}_{17}, \mathrm{MW}=2947.37$ ] suitable for $\mathrm{X}$-ray analysis were grown by slow evaporation of an acetone solution of $\mathbf{1}_{\mathrm{Na} 2}$ with 5 equiv of BTMA bromide and a single dark red crystal with dimensions $0.20 \times 0.11 \times 0.09 \mathrm{~mm}^{3}$ was selected for intensity measurements. The unit cell was triclinic with the space group $P-1$. Lattice constants with $\mathrm{Z}=2, r_{\text {calcd }}=1.115 \mathrm{~g} \mathrm{~cm}^{-3}$, $\mu\left(\mathrm{Mo}_{\mathrm{K} \alpha}\right)=0.070 \mathrm{~mm}^{-1}, F(000)=3,160$, and $2 \theta_{\max }=54.87^{\circ}$ were $a=18.168(3) \AA, b=22.080(3), c$ $=25.875(4) \AA, \alpha=113.034(13)^{\circ}, \beta=94.725(13)^{\circ}, \gamma=108.813(19)^{\circ}$, and $V=8779(2) \AA^{3}$. A total of 60,620 reflections were collected, of which 30,373 reflections were independent $\left(R_{\text {int }}=0.0681\right)$. The structure was refined to final $R_{1}=0.1918$ for 21,019 data $[I>2 \sigma(I)]$ with 2,113 parameters and $w R_{2}=0.4700$ for all data, $G O F=1.193$, and residual electron density $\max / \min =1.356 /-0.576 \mathrm{e}^{-3}$. The ORTEP drawing is shown in Figure S24 and crystal data and structure refinement are listed in Table S1.

Data collection and processing were conducted using the Rigaku CrystalClear software package. ${ }^{\mathrm{S} 2}$ The structure was solved by direct methods using Sir2014 ${ }^{\mathrm{S} 3}$ and refined by full-matrix least squares methods on $F^{2}$ with SHELXL-97 program ${ }^{\mathrm{S} 4}$ using Yadokari-XG 2009. ${ }^{\mathrm{S} 5}$ All nonhydrogen atoms were refined anisotropically. All hydrogen atoms were calculated geometrically and refined using the riding model. Crystallographic data have been deposited at the CCDC (12 Union Road, Cambridge CB2 1EZ, UK) and copies can be obtained on request, free of charge, by quoting the publication citation and the deposition number 1559425. 

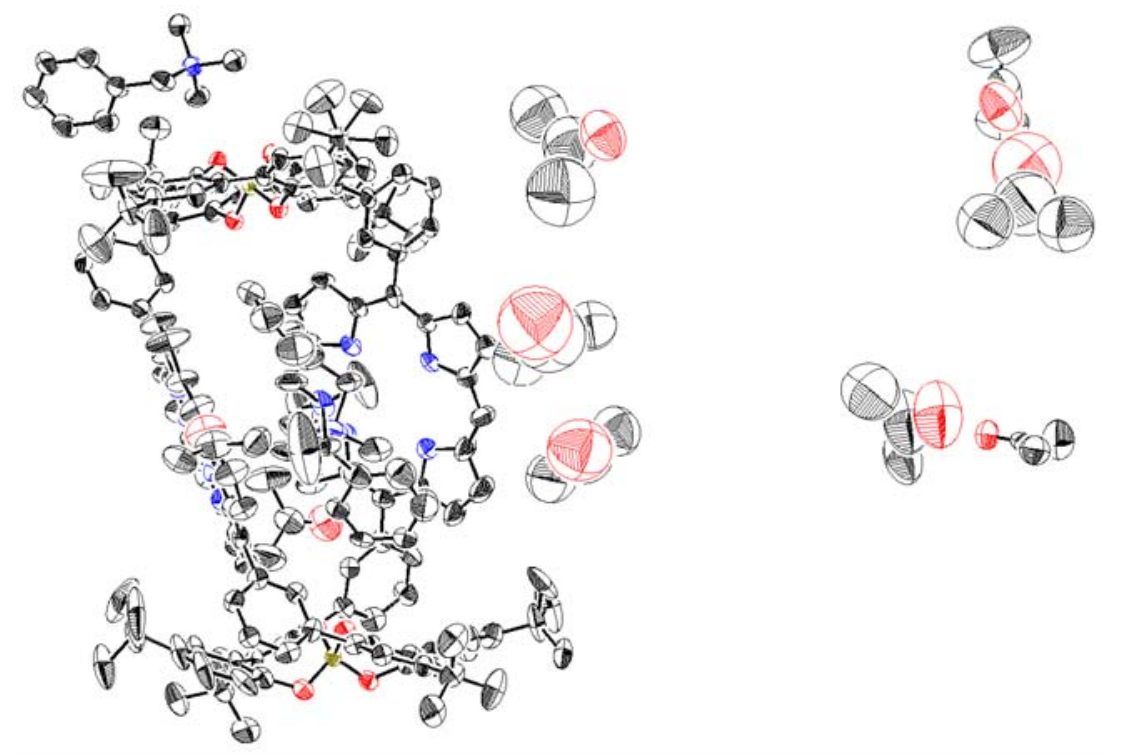

Figure S24. ORTEP drawing of the crystal structure of $\mathbf{1}_{\text {BTMA2 }}$ with thermal ellipsoids at $50 \%$ probability.

Table S1. Crystal data and structure refinement for $\mathbf{1}_{\mathbf{B T M A 2}}$.

Empirical formula

Formula weight

Temperature

Wavelength

Crystal system

Space group

Unit cell dimensions

Volume

Z

Density (calculated)

Absorption coefficient

$\mathrm{F}(000)$

Crystal size

Theta range for data collection

Index ranges

Reflections collected

Independent reflections

Completeness to theta $=25.00^{\circ}$

Absorption correction

Max. and min. transmission

Refinement method

Data / restraints / parameters

Goodness-of-fit on $\mathrm{F}^{2}$

Final R indices [ $I>2 \operatorname{sigma}(I)]$

$R$ indices (all data)

Largest diff. peak and hole

CCDC reference number
$\mathrm{C}_{191} \mathrm{H}_{218} \mathrm{~B}_{2} \mathrm{~N}_{10} \mathrm{O}_{17}$

2947.37

$113(2) \mathrm{K}$

$0.71075 \AA$

Triclinic

$P-1$

$a=18.168(3) \AA$

$b=22.080(3) \AA$

$c=25.875(4) \AA$

9699(5) $\AA^{3}$

2

$1.115 \mathrm{Mg} / \mathrm{m}^{3}$

$0.070 \mathrm{~mm}^{-1}$

3160

$0.20 \times 0.11 \times 0.09 \mathrm{~mm}^{3}$

3.01 to $25.00^{\circ}$.

$-30<=\mathrm{h}<=30,-30<=\mathrm{k}<=30,-16<=\mathrm{l}<=17$

60620

$30373\left[R_{\text {int }}=0.0681\right]$

$98.2 \%$

Semi-empirical from equivalents

0.9937 and 0.9860

Full-matrix least-squares on $\mathrm{F}^{2}$

30373 / 440 / 2113

1.193

$R_{1}=0.1918, w R_{2}=0.4415$

$R_{1}=0.2315, w R_{2}=0.4700$

1.356 and $-0.576 \mathrm{e}^{-3}$

1559425 


\section{Theoretical Studies on the Mechanism of Guest Encapsulation within the Helicate}

\section{5-1. Theoretical Methods And Background}

\section{Umbrella Sampling}

In a system consisting of $N$ atoms, the state $X$ specified by the coordinates $q$ and momenta $p$ can be written as

$$
\begin{aligned}
X & =\{q, p\}, \\
q & =\left(\boldsymbol{q}_{1}, \boldsymbol{q}_{2}, \cdots, \boldsymbol{q}_{N}\right), \\
p & =\left(\boldsymbol{p}_{1}, \boldsymbol{p}_{2}, \cdots, \boldsymbol{p}_{N}\right) .
\end{aligned}
$$

In umbrella sampling (US) method, ${ }^{\mathrm{S} 6}$ we use an umbrella potential $V(q)$, which is defined by following equation:

$$
V(q)=\frac{1}{2} k\{\xi(q)-d\}^{2},
$$

where $\xi(q)$ is a reaction coordinate, $k$ is a force constant (an adjustable parameter), and $d$ is the midpoint value of reaction coordinate in umbrella potential. The umbrella potential $V(q)$ is added to the original potential energy $E_{0}$, which is based on either classical or quantum mechanics, and the total potential energy $E(q)$ is defined by:

$$
E(q)=E_{0}(q)+V(q)
$$

The umbrella sampling simulation allows the system to explore the region around $\xi(q)=d$, which is often difficult to take samples during conventional Monte Carlo (MC) or molecular dynamics (MD) simulations.

In a conventional US simulation, independent US simulations at temperature $T_{0}$ are performed with different umbrella potentials $V_{m}(m=1,2, \cdots M)$ which have dependent midpoint distances $d_{m}(m=1,2, \cdots, M)$ and force constants $k_{m}(m=1,2, \cdots, M)$

$$
V_{m}(q)=\frac{1}{2} k_{m}\left\{\xi(q)-d_{m}\right\}^{2}
$$

Therefore, the $m$-th total potential energy $E_{m}(q)$ is given by the following equation:

$$
E_{m}(q)=E_{0}(q)+V_{m}(q)
$$

By self-consistently solving the following equations of the weighted histogram analysis method (WHAM), ${ }^{\text {S7-S9 }}$ the free energy and other physical quantities of unbiased original system can be calculated based on the $M$ different US simulations. The probability distribution $P_{T_{0}}(\xi)$ of the original unbiased system $f_{m}$ and the "dimensionless" Helmholtz free energy can be obtained by

$$
P_{T_{0}}(\xi)=\frac{\sum_{m=1}^{M} N_{m}(\xi)}{\sum_{m=1}^{M} n_{m} e^{f_{m}-\beta_{0} V_{m}(\xi)}},
$$




$$
e^{-f_{m}}=\sum_{\xi} P_{T_{0}}(\xi) e^{-\beta_{0} E_{m}(\xi)},
$$

where $N_{m}(\xi)$ is the distributions of reaction coordinate, $n_{m}$ is the total number of samples for the $m$-th simulation. The potential of mean force (PMF) $F_{T_{0}}(\xi)$, which is the Helmholtz free energy as a function of the reaction coordinate $\xi$ in the original unbiased system, is given by the following equation:

$$
F_{T_{0}}(\xi)=-k_{\mathrm{B}} T_{0} \ln P_{T_{0}}(\xi) .
$$

The expectation value of a physical quantity $A$ of the original unbiased system is given by the following equation:

$$
\langle A\rangle=\frac{\sum_{\xi} A(\xi) P_{T_{0}}(\xi)}{\sum_{\xi} P_{T_{0}}(\xi)} .
$$

\section{5-2. Computational Details}

\section{5-2-1. General Descriptions for DFTB/US-MD}

We investigated the complexation processes of $\mathbf{1}^{2-} \supset \mathbf{G} 4$ and $\mathbf{1}_{(\mathbf{B T M A}) 2} \supset \mathbf{B T M A}^{+}$by performing self-consistent charge density functional tight-binding (SCC-DFTB) ${ }^{\mathrm{S} 10}$ molecular dynamics (MD) simulations with umbrella sampling (US), which we refer to as DFTB/US-MD. The DFTB method is an approximate density functional theory (DFT) ${ }^{\mathrm{S} 11, \mathrm{~S} 12}$ utilizing parameterized Hamiltonian and overlap matrix elements, and the DFTB $+\operatorname{program}^{\mathrm{S} 13}$ was used to perform DFTB calculations. The DFTB/US-MD methodology has been implemented recently in the original DFTB+ program. ${ }^{\text {S14 }}$

We set a reaction coordinate $\xi(\boldsymbol{r})$ in the US as a distance between the geometric centers of a guest molecule $\boldsymbol{G}\left(\boldsymbol{r}_{\text {guest }}\right)$ and a host $\boldsymbol{G}\left(\boldsymbol{r}_{\text {host }}\right)$ molecule as follows:

$$
\xi(\boldsymbol{r})=\left|\boldsymbol{G}\left(\boldsymbol{r}_{\text {host }}\right)-\boldsymbol{G}\left(\boldsymbol{r}_{\text {guest }}\right)\right| .
$$

The $\xi(\boldsymbol{r})=0$ means that the guest molecule is located at the center of the host molecule. In other words, the guest is accommodated and the $\mathbf{1}^{2-} \supset \mathbf{G 4}$ and $\mathbf{1}_{(\mathbf{B T M A}) 2} \supset \mathbf{B T M A}^{+}$forms planar geometry. As $\xi(\boldsymbol{r})$ is larger than 0 , the guest molecule moves away from the host molecule.

After the DFTB/US-MD simulations, we optimized the geometries of planar and pacman-like geometry of $\mathbf{1}^{2-} \supset \mathbf{G 4}$ and $\mathbf{1}_{(\mathbf{B T M A}) 2} \supset \mathbf{B T M A}^{+}$, which were obtained by the DFTB/US-MD simulations, using resolution of identity DFT (RI-DFT) ${ }^{\mathrm{S} 15}$ to calculate the binding energies $\left(E_{\text {bind }}\right)$ of these molecules as follows:

$$
E_{\text {bind }}=E_{\text {complex }}-\left(E_{\text {host }}+E_{\text {guest }}\right)
$$

where $E_{\text {comlex }}$ is the energy of the host-guest complex, $E_{\text {host }}$ is the energy of the optimized host, and $E_{\text {guest }}$ is the energy of the optimized guest, respectively. 


\section{5-2-2. DFTB/US-MD Simulations of $1^{2-} \supset$ G4 and $1_{(\text {(BTMA)2 }} \supset \mathrm{BTMA}^{+}$}

The planar $\mathbf{1}^{2-} \supset \mathbf{G 4}$ obtained by X-ray analysis was used as the initial geometry for the DFTB/US-MD simulation as shown in Figure S25. In the initial structure, tertiary butyl groups were replaced by hydrogen atoms to reduce computational costs.

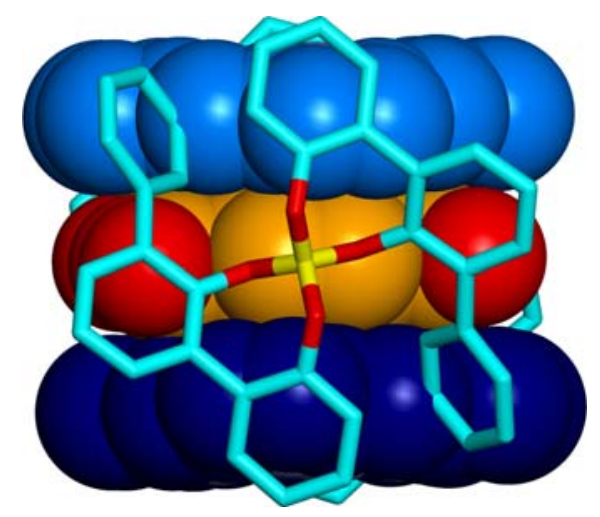

Figure S25. The initial geometry in the DFTB/US-MD simulations of planar $\mathbf{1}^{2-} \supset \mathbf{G 4}$ for each window in US.

In the US, we consider each umbrella potential (so-called window) which has a different force constant value $k_{m}$ and midpoint value $d_{m}$ as a spring restraint between the host and guest molecules as schematically shown in Figure S26

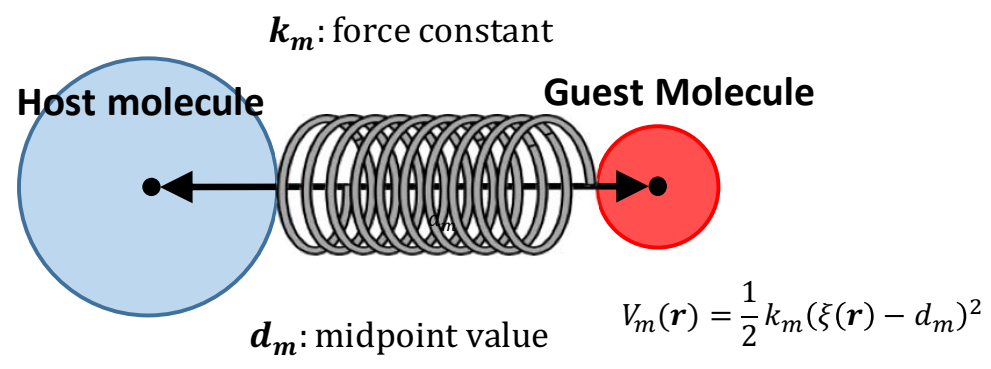

Figure S26. Schematic image of the US simulation.

The $\mathbf{G 4}$ was pulled out from the inside of the $\mathbf{1}$ and restrained at the midpoint value $d_{m}$ of the umbrella potential. We performed the DFTB/US-MD simulations for 50 ps per window where time step was 1.0 fs with $M=48$ umbrella potentials. We set $k_{m}=50.0 \mathrm{kcal} / \mathrm{mol} \cdot \AA^{2}$ for all windows. The $d_{m}$ values were chosen to be $0.0,0.4,0.8,1.2,1.6,2.0,2.4,2.8,3.2,3.6,4.0,4.4,4.8,5.2,5.6$, 
6.0, 6.6, 7.0, 7.4, 7.8, 8.2, 8.6, 9.0, 9.4, 9.8, 10.2, 10.6, 11.0, 11.4, 11.8, 12.2, 12.6, 13.0, 13.5, 14.0, $14.5,15.0,15.5,16.0,16.5,17.0,17.5,18.0,18.5,19.0,19.5,20.0$, and $20.5 \AA$ for each window. The temperature in the MD simulations was set to be $300.0 \mathrm{~K}$ controlled by the Nośe -Hoover chain method $^{\mathrm{S} 16}$ in NVT ensemble. The UFF type dispersion correction ${ }^{\mathrm{S} 17}$ was included in all calculations. The mio parameter set, ${ }^{\mathrm{S} 10}$ rscc-materials set, ${ }^{\mathrm{S} 18}$ and borg set ${ }^{\mathrm{S} 19}$ were employed for $\mathrm{X}$ and $\mathrm{Y}(\mathrm{X}, \mathrm{Y}=\mathrm{C}, \mathrm{H}, \mathrm{O}$, and $\mathrm{N})$, for $\mathrm{B}$ and $\mathrm{X}(\mathrm{X}=\mathrm{C}, \mathrm{O}$ and $\mathrm{N})$, and for $\mathrm{B}$ and $\mathrm{H}$ elements pairs, respectively.

The computational conditions employed for $\mathbf{1}_{(\mathbf{B T M A}) 2} \supset \mathbf{B T M A}^{+}$were similar to those for the $\mathbf{1}^{2-}$ $\supset \mathbf{G 4}$, except for the window with $M=16$ umbrella potentials. We set $k$ values to be 50.0 $\mathrm{kcal} / \mathrm{mol} \cdot \AA^{2}$ for all windows, and $d_{m}$ values were chosen to be $0.0,0.6,1.2,1.8,2.4,3.0,3.6,4.2$, 4.8, 5.4, 6.0, 6.6, 7.2, 7.8, 8.4, and 9.0 A. The pacman-like geometry obtained by X-ray analysis was employed as the initial geometry (Figure S27), and tertiary butyl groups were replaced by hydrogen atoms.

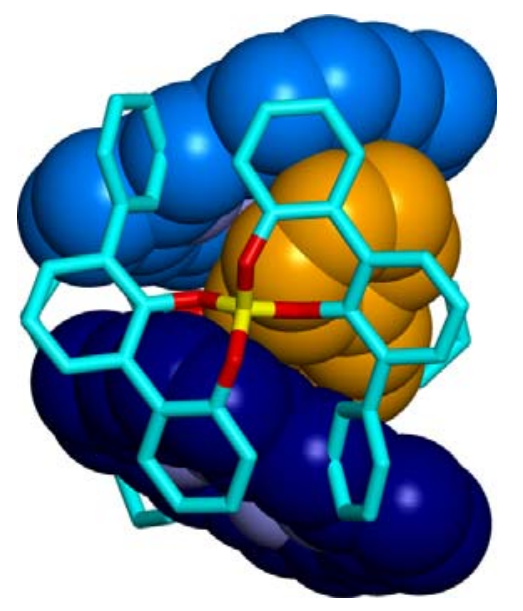

Figure S27. The initial geometry in the DFTB/US-MD simulation of pacman-like structure of

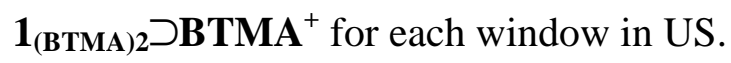

We optimized the planar and pacman forms of $\mathbf{1}^{2-} \supset \mathbf{G 4}$ and $\mathbf{1}_{(\text {(BTMA)2 }} \supset$ BTMA $^{+}$obtained from DFTB/US-MD simulations as shown in Figure S28 to evaluate the $E_{\text {bind }}$ values at the RI-TPSS$\mathrm{D} 3 /$ def-SV $(\mathrm{P})^{\mathrm{S} 15, \mathrm{~S} 20, \mathrm{~S} 21}$ level of theory including the D3 dispersion corrections ${ }^{\mathrm{S} 22, \mathrm{~S} 23}$ as implemented in the Turbomole package. ${ }^{\text {S24 }}$ 
(a) Planar form

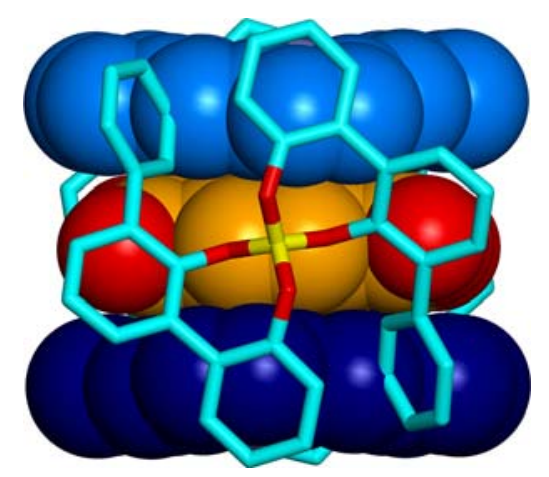

(c)Planar form

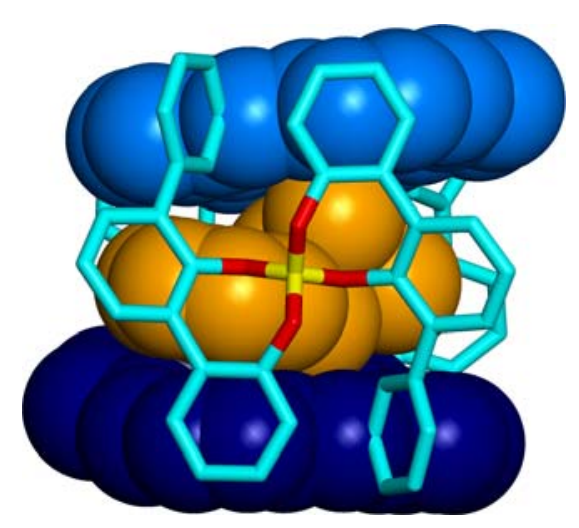

(b) Pacman form

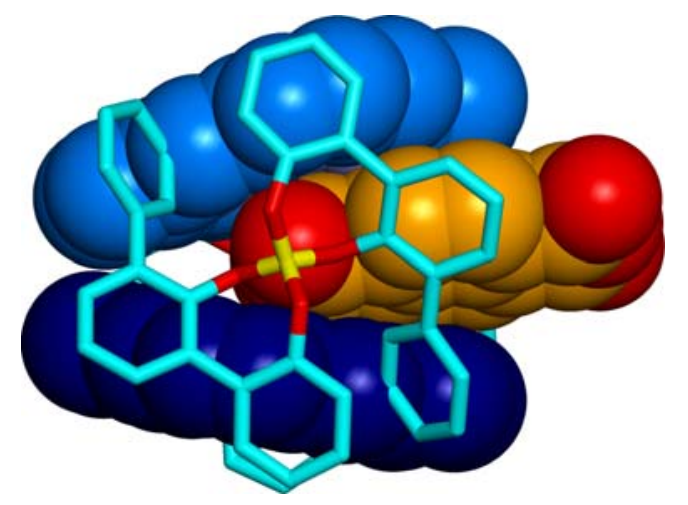

(d) Pacman form

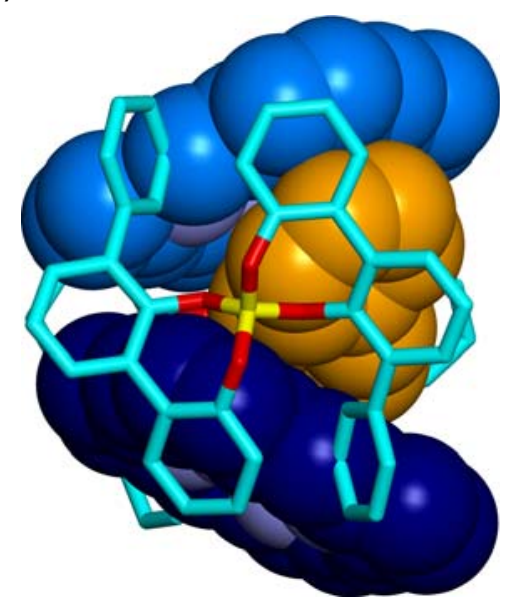

Figure S28. The initial geometries of planar $(a, c)$ and packman $(b, d)$ forms of $\mathbf{1}^{2-} \supset \mathbf{G 4}(a, b)$ and $\mathbf{1}_{\text {(BTMA)2 }} \supset$ BTMA $^{+}(\mathrm{c}, \mathrm{d})$, respectively, used in the RI-DFT optimizations. 

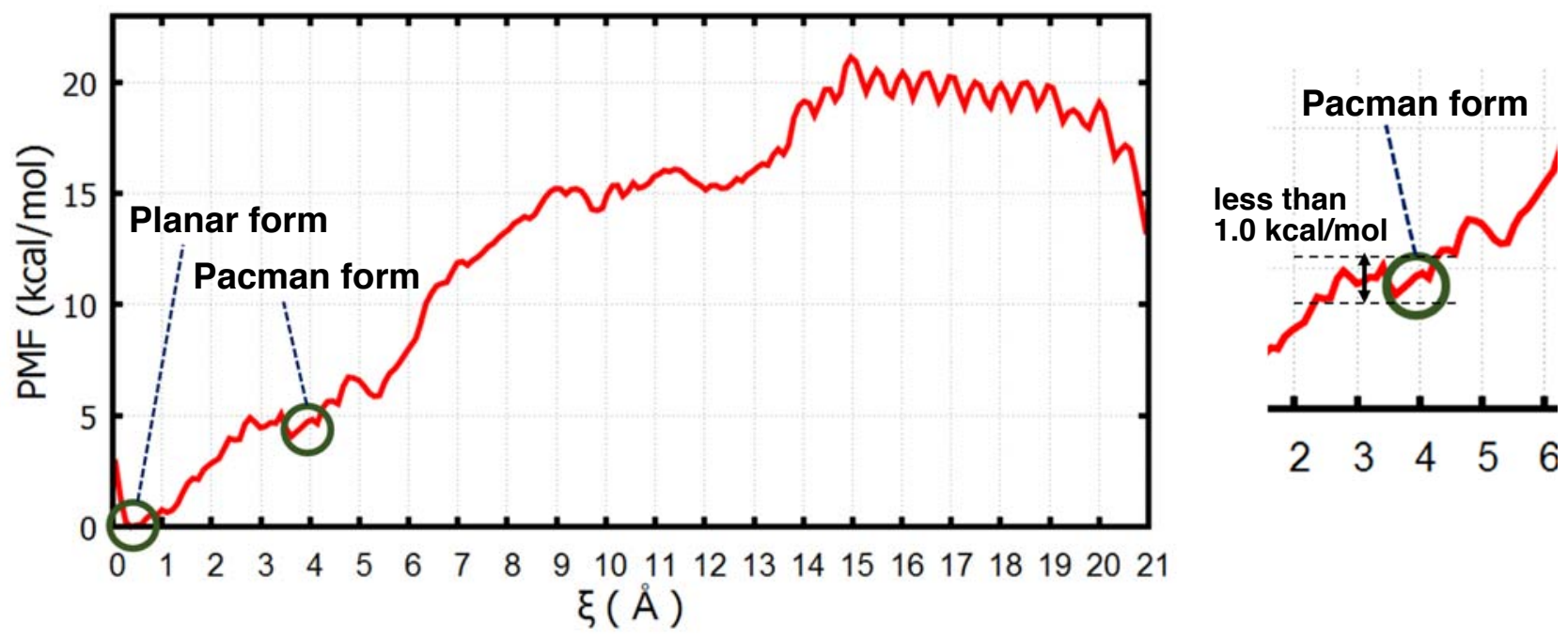

Figure S29. The PMF of $\mathbf{1}^{2-} \supset \mathbf{G 4}$ obtained by the DFTB/US-MD simulations. The planar form is located at around $\xi(\boldsymbol{r})=0.0$ and the pacman form is located at around $\xi(\boldsymbol{r})=4.0$.

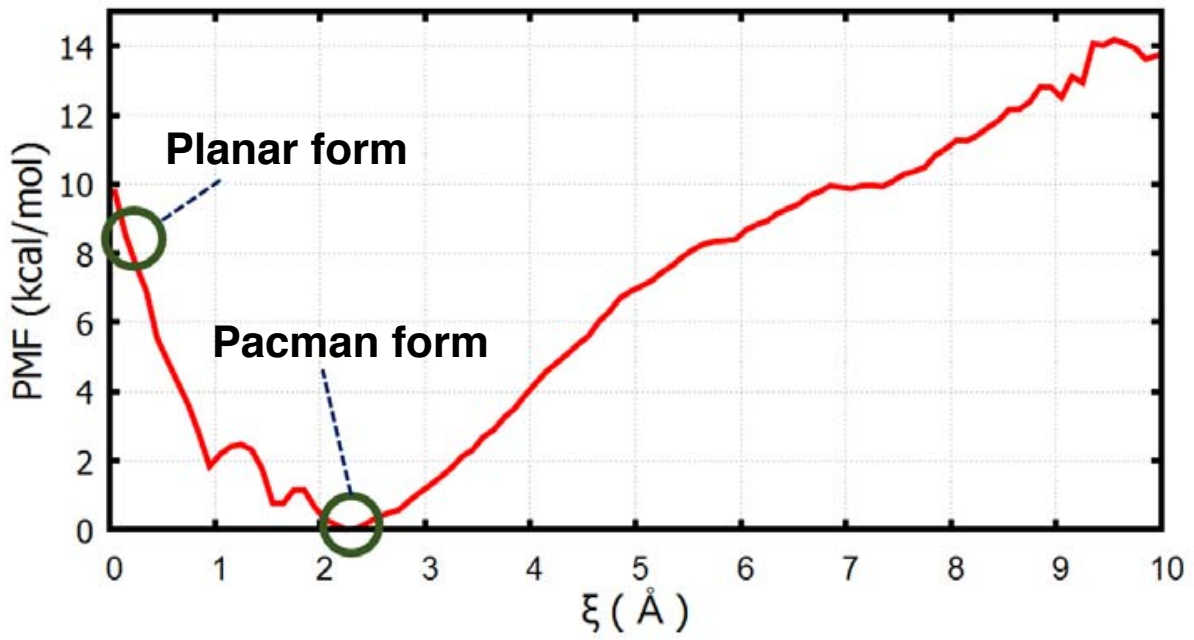

Figure S30. The PMF of $\mathbf{1}_{(\mathbf{B T M A}) 2} \supset \mathrm{BTMA}^{+}$obtained by DFTB/US-MD simulations. The planar form is located at around $\xi(\boldsymbol{r})=0.0$ and the pacman form is located at around $\xi(\boldsymbol{r})=2.2$. 
Table S2. Cartesian coordinate of planar form of $\mathbf{1}^{2-} \supset \mathbf{G} \mathbf{4}$ calculated by RI-DFT.

\# Sum of imaginary frequencies $=0$

\# Total Energy (hartree) $=-6383.141669678$

\begin{tabular}{|c|c|c|c|c|c|c|c|}
\hline Atom & $\mathrm{x}$ & $\mathrm{y}$ & $\mathrm{Z}$ & Atom & $\mathrm{x}$ & $\mathrm{y}$ & $\mathrm{Z}$ \\
\hline $\mathrm{B}$ & -7.33105 & 1.06739 & 0.90955 & $\mathrm{C}$ & 8.16324 & 3.65624 & -1.08196 \\
\hline B & 7.34834 & -1.03677 & -0.87784 & $\mathrm{C}$ & 7.68436 & 3.87897 & -2.38386 \\
\hline $\mathrm{C}$ & -7.79661 & -4.04279 & 1.27466 & $\mathrm{C}$ & 7.43041 & 2.78133 & -3.21539 \\
\hline $\mathrm{C}$ & -7.85199 & -3.29799 & 0.08975 & $\mathrm{C}$ & -0.48210 & 0.61090 & 2.98587 \\
\hline $\mathrm{C}$ & -7.99479 & -1.89291 & 0.09592 & $\mathrm{C}$ & 1.89304 & 0.14129 & 2.41022 \\
\hline $\mathrm{C}$ & -8.09413 & -1.23053 & 1.35286 & $\mathrm{C}$ & 1.51038 & -0.04987 & 0.99214 \\
\hline $\mathrm{C}$ & -8.05488 & -1.98925 & 2.54246 & $\mathrm{C}$ & 0.14528 & 0.07990 & 0.61461 \\
\hline $\mathrm{C}$ & -7.89929 & -3.37885 & 2.50862 & $\mathrm{C}$ & -0.85390 & 0.40290 & 1.56967 \\
\hline $\mathrm{C}$ & -8.04411 & -1.13941 & -1.18199 & $\mathrm{C}$ & -2.18440 & 0.52951 & 1.17644 \\
\hline $\mathrm{C}$ & -7.31483 & 0.07659 & -1.33795 & $\mathrm{C}$ & -2.56627 & 0.30662 & -0.16163 \\
\hline $\mathrm{C}$ & -7.26606 & 0.71624 & -2.61476 & $\mathrm{C}$ & -1.60281 & -0.01464 & -1.11935 \\
\hline $\mathrm{C}$ & -7.98786 & 0.14520 & -3.68518 & $\mathrm{C}$ & -0.23463 & -0.11958 & -0.74610 \\
\hline $\mathrm{C}$ & -8.73799 & -1.02492 & -3.52647 & $\mathrm{C}$ & 0.76632 & -0.42357 & -1.70495 \\
\hline $\mathrm{C}$ & -8.75355 & -1.66340 & -2.28146 & $\mathrm{C}$ & 2.10114 & -0.52425 & -1.31794 \\
\hline $\mathrm{C}$ & -6.44392 & 1.92886 & -2.87524 & $\mathrm{C}$ & 2.47695 & -0.35223 & 0.03012 \\
\hline $\mathrm{C}$ & -5.15804 & 2.06512 & -2.31686 & $\mathrm{C}$ & -1.99631 & -0.26640 & -2.52430 \\
\hline $\mathrm{C}$ & -4.31301 & 3.14082 & -2.64117 & $\mathrm{C}$ & 0.39339 & -0.62368 & -3.12252 \\
\hline $\mathrm{C}$ & -4.77849 & 4.13351 & -3.52699 & $\mathrm{H}$ & -7.74216 & -3.80852 & -0.87574 \\
\hline $\mathrm{C}$ & -6.06549 & 4.02971 & -4.07403 & $\mathrm{H}$ & -8.13362 & -1.44853 & 3.49018 \\
\hline $\mathrm{C}$ & -6.88749 & 2.93937 & -3.75825 & $\mathrm{H}$ & -7.92705 & 0.61994 & -4.67263 \\
\hline $\mathrm{C}$ & -2.93544 & 3.19802 & -2.05709 & $\mathrm{H}$ & -9.33006 & -2.58710 & -2.14401 \\
\hline $\mathrm{C}$ & -2.83131 & 3.41196 & -0.66694 & $\mathrm{H}$ & -4.79715 & 1.28236 & -1.65297 \\
\hline $\mathrm{C}$ & -1.89944 & 3.69008 & 1.37831 & $\mathrm{H}$ & -4.13123 & 4.98361 & -3.77512 \\
\hline $\mathrm{C}$ & -3.33129 & 3.76021 & 1.52448 & $\mathrm{H}$ & -6.43546 & 4.81213 & -4.75016 \\
\hline $\mathrm{C}$ & -3.89941 & 3.59550 & 0.27881 & $\mathrm{H}$ & -7.89672 & 2.87987 & -4.18507 \\
\hline $\mathrm{C}$ & -0.95510 & 3.79096 & 2.40731 & $\mathrm{H}$ & 4.95434 & 0.59288 & 1.29113 \\
\hline $\mathrm{C}$ & 0.44380 & 3.65018 & 2.34915 & $\mathrm{H}$ & 8.41255 & 2.28973 & 3.23340 \\
\hline $\mathrm{C}$ & 2.48392 & 3.25510 & 1.67898 & $\mathrm{H}$ & 7.44415 & 4.56580 & 2.96152 \\
\hline $\mathrm{C}$ & 2.56473 & 3.47168 & 3.12368 & $\mathrm{H}$ & 5.21046 & 4.86474 & 1.86065 \\
\hline $\mathrm{C}$ & 1.28739 & 3.72157 & 3.54042 & $\mathrm{H}$ & 8.61250 & -3.68994 & 3.37995 \\
\hline $\mathrm{C}$ & 3.58922 & 2.89053 & 0.86673 & $\mathrm{H}$ & 7.92699 & 0.41695 & 4.52799 \\
\hline $\mathrm{C}$ & 3.47691 & 2.60780 & -0.51013 & $\mathrm{H}$ & 7.60017 & -4.39745 & -2.36972 \\
\hline $\mathrm{C}$ & 2.54912 & 2.36998 & -2.56275 & $\mathrm{H}$ & 6.81749 & -6.61243 & -1.48719 \\
\hline $\mathrm{C}$ & 3.94660 & 2.03191 & -2.65969 & $\mathrm{H}$ & 6.81669 & -4.95984 & 2.51407 \\
\hline $\mathrm{C}$ & 4.51372 & 2.18217 & -1.41160 & $\mathrm{H}$ & -6.02146 & 5.85057 & 2.50821 \\
\hline $\mathrm{C}$ & 1.61434 & 2.34354 & -3.60537 & $\mathrm{H}$ & -8.16755 & 3.75839 & -1.46653 \\
\hline $\mathrm{C}$ & 0.22935 & 2.59096 & -3.56748 & $\mathrm{H}$ & -7.26003 & 6.09180 & -1.63265 \\
\hline $\mathrm{C}$ & -1.81328 & 2.97294 & -2.89592 & $\mathrm{H}$ & -6.30204 & 1.53275 & 6.43509 \\
\hline $\mathrm{C}$ & -1.90268 & 2.68434 & -4.32740 & $\mathrm{H}$ & -7.44502 & 5.05252 & 4.21212 \\
\hline $\mathrm{C}$ & -0.62302 & 2.45078 & -4.74681 & $\mathrm{H}$ & -4.43762 & 0.05781 & 2.70339 \\
\hline
\end{tabular}




\begin{tabular}{|c|c|c|c|c|c|c|c|}
\hline $\mathrm{C}$ & 4.93925 & 2.74137 & 1.49660 & $\mathrm{H}$ & -4.20075 & -3.66487 & 4.88258 \\
\hline $\mathrm{C}$ & 5.50827 & 1.46341 & 1.63825 & $\mathrm{H}$ & -6.03914 & -2.87184 & 6.39110 \\
\hline $\mathrm{C}$ & 6.74660 & 1.26689 & 2.28175 & $\mathrm{H}$ & -7.02231 & -0.60838 & 6.08827 \\
\hline $\mathrm{C}$ & 7.43117 & 2.40830 & 2.75666 & $\mathrm{H}$ & 4.27445 & -1.99546 & -2.29412 \\
\hline $\mathrm{C}$ & 6.88723 & 3.69055 & 2.60082 & $\mathrm{H}$ & 6.49251 & -4.42781 & -5.07937 \\
\hline $\mathrm{C}$ & 5.64233 & 3.86358 & 1.98011 & $\mathrm{H}$ & 5.03517 & -6.36771 & -4.54295 \\
\hline $\mathrm{C}$ & 7.27756 & -0.10067 & 2.52976 & $\mathrm{H}$ & 3.14074 & -6.11677 & -2.91852 \\
\hline $\mathrm{C}$ & 7.17239 & -1.15086 & 1.56810 & $\mathrm{H}$ & 8.23119 & 1.29501 & -5.40864 \\
\hline $\mathrm{C}$ & 7.63853 & -2.45930 & 1.89247 & $\mathrm{H}$ & 6.29075 & -2.47406 & -6.22517 \\
\hline $\mathrm{C}$ & 8.23658 & -2.68492 & 3.14859 & $\mathrm{H}$ & 8.74507 & 2.15029 & 0.37949 \\
\hline $\mathrm{C}$ & 8.36300 & -1.65581 & 4.08812 & $\mathrm{H}$ & 8.35240 & 4.49968 & -0.40505 \\
\hline $\mathrm{C}$ & 7.87408 & -0.38233 & 3.77759 & $\mathrm{H}$ & 7.02798 & 2.94890 & -4.22326 \\
\hline $\mathrm{C}$ & 7.42777 & -3.59022 & 0.95515 & $\mathrm{H}$ & -3.85290 & 3.90229 & 2.47297 \\
\hline $\mathrm{C}$ & 7.63762 & -3.44228 & -0.44612 & $\mathrm{H}$ & -4.95912 & 3.58402 & 0.02630 \\
\hline $\mathrm{C}$ & 7.42976 & -4.54717 & -1.29948 & $\mathrm{H}$ & -1.38005 & 3.95128 & 3.40434 \\
\hline $\mathrm{C}$ & 7.00261 & -5.78004 & -0.79571 & $\mathrm{H}$ & 3.47293 & 3.39046 & 3.72340 \\
\hline $\mathrm{C}$ & 6.79139 & -5.93767 & 0.58437 & $\mathrm{H}$ & 0.92585 & 3.89334 & 4.55778 \\
\hline $\mathrm{C}$ & 7.01145 & -4.85016 & 1.43923 & $\mathrm{H}$ & 4.44421 & 1.70338 & -3.57437 \\
\hline $\mathrm{C}$ & -6.60108 & 6.13546 & 0.44340 & $\mathrm{H}$ & 5.54990 & 2.00523 & -1.12506 \\
\hline $\mathrm{C}$ & -6.51514 & 5.40455 & 1.63502 & $\mathrm{H}$ & 2.02000 & 2.03721 & -4.57584 \\
\hline $\mathrm{C}$ & -6.99911 & 4.08151 & 1.73689 & $\mathrm{H}$ & -2.82852 & 2.62626 & -4.90237 \\
\hline $\mathrm{C}$ & -7.59895 & 3.49205 & 0.58763 & $\mathrm{H}$ & -0.27650 & 2.16243 & -5.74284 \\
\hline $\mathrm{C}$ & -7.69913 & 4.24125 & -0.60404 & $\mathrm{H}$ & 0.57138 & -2.26217 & 5.72504 \\
\hline $\mathrm{C}$ & -7.19890 & 5.54495 & -0.68273 & $\mathrm{H}$ & -2.11653 & -1.87551 & 5.52683 \\
\hline $\mathrm{C}$ & -6.88918 & 3.33885 & 3.01690 & $\mathrm{H}$ & 2.44986 & -2.78039 & 4.05086 \\
\hline $\mathrm{C}$ & -6.48400 & 1.97011 & 3.03366 & $\mathrm{H}$ & 4.95569 & -3.58491 & -0.11506 \\
\hline $\mathrm{C}$ & -6.27246 & 1.30815 & 4.28240 & $\mathrm{H}$ & 4.56391 & -3.06378 & 2.51102 \\
\hline $\mathrm{C}$ & -6.49876 & 2.02841 & 5.47628 & $\mathrm{H}$ & -1.22326 & -3.93138 & -4.48349 \\
\hline $\mathrm{C}$ & -6.92653 & 3.36000 & 5.46431 & $\mathrm{H}$ & 1.48104 & -4.20306 & -4.30383 \\
\hline $\mathrm{C}$ & -7.11307 & 4.00669 & 4.23750 & $\mathrm{H}$ & -3.09267 & -3.32205 & -2.82418 \\
\hline $\mathrm{C}$ & -5.77220 & -0.09050 & 4.38525 & $\mathrm{H}$ & -5.52897 & -1.95996 & 1.23166 \\
\hline $\mathrm{C}$ & -4.77579 & -0.58187 & 3.51824 & $\mathrm{H}$ & -5.13736 & -2.51753 & -1.38393 \\
\hline $\mathrm{C}$ & -4.18540 & -1.84679 & 3.69635 & $\mathrm{H}$ & -2.92758 & 0.81206 & 1.92327 \\
\hline $\mathrm{C}$ & -4.64334 & -2.67087 & 4.74465 & $\mathrm{H}$ & -3.62053 & 0.36491 & -0.44107 \\
\hline $\mathrm{C}$ & -5.66573 & -2.21947 & 5.59034 & $\mathrm{H}$ & 2.85123 & -0.73108 & -2.08314 \\
\hline $\mathrm{C}$ & -6.21828 & -0.94335 & 5.42096 & $\mathrm{H}$ & 3.52431 & -0.47324 & 0.32065 \\
\hline $\mathrm{C}$ & -3.06637 & -2.28664 & 2.80529 & $\mathrm{H}$ & 0.75968 & -3.38857 & 0.56155 \\
\hline $\mathrm{C}$ & -1.76618 & -2.45353 & 3.35340 & $\mathrm{H}$ & -1.44018 & -3.02942 & 0.72655 \\
\hline $\mathrm{C}$ & 0.39400 & -2.74648 & 3.51024 & $\mathrm{H}$ & 1.41328 & 2.96264 & -0.81809 \\
\hline $\mathrm{C}$ & -0.07082 & -2.39339 & 4.84993 & $\mathrm{H}$ & -0.73236 & 3.33467 & -0.40920 \\
\hline $\mathrm{C}$ & -1.42067 & -2.20286 & 4.75279 & $\mathrm{~N}$ & -1.64645 & 3.48220 & 0.03893 \\
\hline $\mathrm{C}$ & 1.75777 & -2.92609 & 3.21402 & $\mathrm{~N}$ & 1.18903 & 3.37218 & 1.23418 \\
\hline $\mathrm{C}$ & 2.38133 & -3.18373 & 1.98628 & $\mathrm{~N}$ & 2.31223 & 2.70442 & -1.24636 \\
\hline
\end{tabular}




\begin{tabular}{cccccccc}
$\mathrm{C}$ & 2.71301 & -3.59937 & -0.21443 & $\mathrm{~N}$ & -0.51063 & 2.91619 & -2.46195 \\
$\mathrm{C}$ & 4.00492 & -3.49326 & 0.40918 & $\mathrm{~N}$ & -0.64961 & -2.78645 & 2.62407 \\
$\mathrm{C}$ & 3.80159 & -3.23410 & 1.74842 & $\mathrm{~N}$ & 1.76697 & -3.41057 & 0.77304 \\
$\mathrm{C}$ & 2.41933 & -3.84007 & -1.57254 & $\mathrm{~N}$ & -0.03183 & -3.60456 & -1.34353 \\
$\mathrm{C}$ & 1.09647 & -3.85049 & -2.08816 & $\mathrm{~N}$ & -2.42860 & -2.86858 & 0.48757 \\
$\mathrm{C}$ & -1.07053 & -3.61751 & -2.23605 & $\mathrm{O}$ & -8.29522 & 0.09557 & 1.43855 \\
$\mathrm{C}$ & -0.59542 & -3.90056 & -3.58894 & $\mathrm{O}$ & -6.61709 & 0.58319 & -0.29975 \\
$\mathrm{C}$ & 0.76151 & -4.03810 & -3.50001 & $\mathrm{O}$ & 6.57274 & -0.92116 & 0.38221 \\
$\mathrm{C}$ & -2.41821 & -3.32213 & -1.96051 & $\mathrm{O}$ & 8.09744 & -2.29534 & -0.97574 \\
$\mathrm{C}$ & -3.02584 & -2.95754 & -0.75176 & $\mathrm{O}$ & -8.13722 & 2.26085 & 0.62518 \\
$\mathrm{C}$ & -3.34965 & -2.46696 & 1.43510 & $\mathrm{O}$ & -6.23149 & 1.32612 & 1.87677 \\
$\mathrm{C}$ & -4.60502 & -2.28617 & 0.75542 & $\mathrm{O}$ & 6.30319 & -0.93430 & -1.92908 \\
$\mathrm{C}$ & -4.40467 & -2.57877 & -0.57711 & $\mathrm{O}$ & 8.37405 & 0.00800 & -0.98734 \\
$\mathrm{C}$ & 3.57004 & -4.02813 & -2.51220 & $\mathrm{O}$ & -1.24700 & 0.89290 & 3.88126 \\
$\mathrm{C}$ & 4.42593 & -2.94915 & -2.79965 & $\mathrm{O}$ & 0.86854 & 0.46657 & 3.30225 \\
$\mathrm{C}$ & 5.46566 & -3.04923 & -3.74651 & $\mathrm{O}$ & 3.01120 & 0.03374 & 2.86098 \\
$\mathrm{C}$ & 5.66688 & -4.30348 & -4.36745 & $\mathrm{O}$ & -3.12819 & -0.25884 & -2.95313 \\
$\mathrm{C}$ & 4.84737 & -5.39796 & -4.06310 & $\mathrm{O}$ & -0.96565 & -0.54158 & -3.42718 \\
$\mathrm{C}$ & 3.79293 & -5.26570 & -3.14893 & $\mathrm{O}$ & 1.16395 & -0.85527 & -4.02722 \\
$\mathrm{C}$ & 6.26652 & -1.86051 & -4.14850 & $\mathrm{H}$ & 8.82644 & -1.84816 & 5.06446 \\
$\mathrm{C}$ & 6.65349 & -0.83930 & -3.22705 & $\mathrm{H}$ & -9.29177 & -1.44714 & -4.37505 \\
$\mathrm{C}$ & 7.34175 & 0.31862 & -3.69672 & $\mathrm{H}$ & -6.18421 & 7.14907 & 0.38906 \\
$\mathrm{C}$ & 7.67969 & 0.41182 & -5.06167 & $\mathrm{H}$ & 6.43567 & -6.89299 & 0.99068 \\
$\mathrm{C}$ & 7.32811 & -0.59598 & -5.96688 & $\mathrm{H}$ & -7.65071 & -5.12961 & 1.23421 \\
$\mathrm{C}$ & 6.61584 & -1.70916 & -5.50872 & $\mathrm{H}$ & -7.83882 & -3.93995 & 3.45040 \\
$\mathrm{C}$ & 7.62757 & 1.45139 & -2.78168 & $\mathrm{H}$ & 7.48772 & 4.89735 & -2.74200 \\
$\mathrm{C}$ & 8.10530 & 1.23772 & -1.45670 & $\mathrm{H}$ & 7.59083 & -0.50589 & -7.02889 \\
$\mathrm{C}$ & 8.37763 & 2.35000 & -0.63132 & $\mathrm{H}$ & -7.09728 & 3.89532 & 6.40720 \\
\hline & & & & & & &
\end{tabular}

Table S3. Cartesian coordinate of packman form of $\mathbf{1}^{2-} \supset \mathbf{G} 4$ calculated by RI-DFT.

\# Sum of imaginary frequencies $=0$

\# Total Energy (hartree) $=-6383.122557676$

\begin{tabular}{|c|c|c|c|c|c|c|c|}
\hline Atom & $\mathrm{x}$ & $\mathrm{y}$ & $\mathrm{z}$ & Atom & $\mathrm{x}$ & $\mathrm{y}$ & $\mathrm{z}$ \\
\hline $\mathrm{B}$ & -1.29892 & -6.27590 & 3.59747 & $\mathrm{C}$ & 2.04040 & 9.01604 & 0.66624 \\
\hline B & 1.83621 & 6.62635 & -3.41094 & $\mathrm{C}$ & 0.66831 & 9.03851 & 0.96727 \\
\hline $\mathrm{C}$ & -0.42235 & -8.98622 & -0.75707 & $\mathrm{C}$ & -0.25604 & 8.65805 & -0.01384 \\
\hline $\mathrm{C}$ & -1.62052 & -8.36118 & -0.39169 & $\mathrm{H}$ & -2.40991 & -8.23746 & -1.14452 \\
\hline $\mathrm{C}$ & -1.84149 & -7.84263 & 0.90564 & $\mathrm{H}$ & 1.19885 & -8.68272 & 2.24764 \\
\hline $\mathrm{C}$ & -0.79523 & -7.98331 & 1.86695 & $\mathrm{H}$ & -6.54176 & -5.31945 & 1.71607 \\
\hline $\mathrm{C}$ & 0.41492 & -8.60863 & 1.48733 & $\mathrm{H}$ & -4.29752 & -8.60419 & 0.05191 \\
\hline $\mathrm{C}$ & 0.60543 & -9.10378 & 0.19445 & $\mathrm{H}$ & -2.58600 & -3.32158 & 2.52981 \\
\hline $\mathrm{C}$ & -3.14203 & -7.20337 & 1.23143 & $\mathrm{H}$ & -5.04738 & -0.59628 & 4.78109 \\
\hline $\mathrm{C}$ & -3.20228 & -6.03930 & 2.05342 & $\mathrm{H}$ & -6.81750 & -2.36525 & 4.96146 \\
\hline
\end{tabular}




\begin{tabular}{|c|c|c|c|c|c|c|c|}
\hline $\mathrm{C}$ & -4.44049 & -5.35548 & 2.24894 & $\mathrm{H}$ & -6.52674 & -4.54986 & 3.82123 \\
\hline $\mathrm{C}$ & -5.59725 & -5.86837 & 1.62092 & $\mathrm{H}$ & 3.11006 & 4.36698 & -0.93922 \\
\hline $\mathrm{C}$ & -5.55526 & -7.03127 & 0.84533 & $\mathrm{H}$ & 6.19194 & 7.29857 & -0.13016 \\
\hline $\mathrm{C}$ & -4.33518 & -7.69043 & 0.65822 & $\mathrm{H}$ & 5.67231 & 7.16185 & 2.29922 \\
\hline $\mathrm{C}$ & -4.55109 & -4.09362 & 3.03225 & $\mathrm{H}$ & 3.88739 & 5.60195 & 3.12213 \\
\hline $\mathrm{C}$ & -3.53563 & -3.11410 & 3.02228 & $\mathrm{H}$ & 6.24056 & 5.51614 & -5.89731 \\
\hline $\mathrm{C}$ & -3.71832 & -1.84390 & 3.59966 & $\mathrm{H}$ & 7.21643 & 5.93310 & -1.70853 \\
\hline $\mathrm{C}$ & -4.90903 & -1.57409 & 4.30438 & $\mathrm{H}$ & 0.42583 & 5.96562 & -6.73320 \\
\hline $\mathrm{C}$ & -5.89962 & -2.56144 & 4.39169 & $\mathrm{H}$ & 0.97478 & 4.14002 & -8.36607 \\
\hline $\mathrm{C}$ & -5.73443 & -3.79478 & 3.74809 & $\mathrm{H}$ & 4.82149 & 3.64771 & -6.44150 \\
\hline $\mathrm{C}$ & -2.68142 & -0.79250 & 3.37179 & $\mathrm{H}$ & -0.31535 & -3.67950 & 8.00149 \\
\hline $\mathrm{C}$ & -1.36534 & -1.05747 & 3.81055 & $\mathrm{H}$ & -4.28724 & -5.43662 & 5.56972 \\
\hline $\mathrm{C}$ & 0.87676 & -0.85253 & 4.03022 & $\mathrm{H}$ & -4.59505 & -3.69439 & 7.34985 \\
\hline $\mathrm{C}$ & 0.48176 & -2.09876 & 4.63270 & $\mathrm{H}$ & 4.07947 & -6.39164 & 5.27423 \\
\hline $\mathrm{C}$ & -0.88479 & -2.22030 & 4.50739 & $\mathrm{H}$ & 0.99312 & -5.65697 & 8.21223 \\
\hline $\mathrm{C}$ & 2.18086 & -0.36813 & 3.88599 & $\mathrm{H}$ & 1.49342 & -4.30314 & 2.36569 \\
\hline $\mathrm{C}$ & 2.61905 & 0.83231 & 3.29612 & $\mathrm{H}$ & 3.89861 & -6.25748 & -0.63929 \\
\hline $\mathrm{C}$ & 2.69856 & 2.76603 & 2.29455 & $\mathrm{H}$ & 4.60704 & -7.97714 & 1.04680 \\
\hline $\mathrm{C}$ & 4.09064 & 2.36823 & 2.51971 & $\mathrm{H}$ & 3.76378 & -7.84780 & 3.38940 \\
\hline $\mathrm{C}$ & 4.03778 & 1.15618 & 3.14918 & $\mathrm{H}$ & -0.42520 & 3.76454 & -3.14933 \\
\hline $\mathrm{C}$ & 2.32145 & 3.94717 & 1.60405 & $\mathrm{H}$ & -2.47385 & 5.63598 & -6.45674 \\
\hline $\mathrm{C}$ & 0.99203 & 4.27279 & 1.26990 & $\mathrm{H}$ & -2.19803 & 3.55772 & -7.80347 \\
\hline $\mathrm{C}$ & -1.24736 & 4.06910 & 1.04625 & $\mathrm{H}$ & -1.05181 & 1.56452 & -6.82285 \\
\hline $\mathrm{C}$ & -0.83687 & 5.25928 & 0.34663 & $\mathrm{H}$ & -2.29567 & 9.31942 & -1.77512 \\
\hline $\mathrm{C}$ & 0.52874 & 5.38720 & 0.48693 & $\mathrm{H}$ & -3.72085 & 6.31576 & -4.53590 \\
\hline $\mathrm{C}$ & -2.53871 & 3.52687 & 1.07863 & $\mathrm{H}$ & 3.52952 & 8.60093 & -0.87098 \\
\hline $\mathrm{C}$ & -2.97307 & 2.31126 & 1.63823 & $\mathrm{H}$ & 2.78314 & 9.27863 & 1.43083 \\
\hline $\mathrm{C}$ & -3.05108 & 0.37069 & 2.64198 & $\mathrm{H}$ & -1.32412 & 8.62817 & 0.23659 \\
\hline $\mathrm{C}$ & -4.38210 & 0.59529 & 2.07764 & $\mathrm{H}$ & 1.16807 & -2.81976 & 5.08148 \\
\hline $\mathrm{C}$ & -4.33331 & 1.81689 & 1.46234 & $\mathrm{H}$ & -1.50764 & -3.05088 & 4.83573 \\
\hline $\mathrm{C}$ & 3.39193 & 4.88344 & 1.13453 & $\mathrm{H}$ & 2.96420 & -1.03616 & 4.26305 \\
\hline $\mathrm{C}$ & 3.68336 & 4.97908 & -0.23824 & $\mathrm{H}$ & 4.96959 & 2.93794 & 2.21039 \\
\hline $\mathrm{C}$ & 4.71090 & 5.82132 & -0.71978 & $\mathrm{H}$ & 4.86693 & 0.51737 & 3.46766 \\
\hline $\mathrm{C}$ & 5.41501 & 6.60701 & 0.22024 & $\mathrm{H}$ & -1.50661 & 5.91369 & -0.21514 \\
\hline $\mathrm{C}$ & 5.11978 & 6.53289 & 1.58810 & $\mathrm{H}$ & 1.17091 & 6.16142 & 0.06857 \\
\hline $\mathrm{C}$ & 4.12000 & 5.66741 & 2.05230 & $\mathrm{H}$ & -3.29824 & 4.11160 & 0.54563 \\
\hline $\mathrm{C}$ & 5.10051 & 5.82225 & -2.15629 & $\mathrm{H}$ & -5.22259 & -0.09926 & 2.13078 \\
\hline $\mathrm{C}$ & 4.13113 & 5.71653 & -3.19813 & $\mathrm{H}$ & -5.12721 & 2.33074 & 0.91247 \\
\hline $\mathrm{C}$ & 4.55031 & 5.55201 & -4.55084 & $\mathrm{H}$ & 5.37332 & -0.76284 & 0.68256 \\
\hline $\mathrm{C}$ & 5.92534 & 5.61427 & -4.85050 & $\mathrm{H}$ & 4.53743 & -3.27377 & 1.36875 \\
\hline $\mathrm{C}$ & 6.88214 & 5.79044 & -3.84274 & $\mathrm{H}$ & 4.63040 & 0.97900 & -1.07022 \\
\hline $\mathrm{C}$ & 6.46701 & 5.86858 & -2.50798 & $\mathrm{H}$ & 1.84174 & 3.51524 & -4.22494 \\
\hline $\mathrm{C}$ & 3.56258 & 5.19193 & -5.59905 & $\mathrm{H}$ & 3.98768 & 2.95195 & -2.69589 \\
\hline
\end{tabular}




\begin{tabular}{|c|c|c|c|c|c|c|c|}
\hline $\mathrm{C}$ & 2.29374 & 5.83163 & -5.68462 & $\mathrm{H}$ & -3.43109 & -1.93516 & -4.85257 \\
\hline $\mathrm{C}$ & 1.39060 & 5.45130 & -6.69855 & $\mathrm{H}$ & -2.77384 & 0.65545 & -5.29770 \\
\hline $\mathrm{C}$ & 1.71015 & 4.43822 & -7.60776 & $\mathrm{H}$ & -2.32097 & -3.90789 & -3.63103 \\
\hline $\mathrm{C}$ & 2.95398 & 3.79012 & -7.52614 & $\mathrm{H}$ & 0.41517 & -6.37865 & -0.35003 \\
\hline $\mathrm{C}$ & 3.86242 & 4.17419 & -6.53189 & $\mathrm{H}$ & -1.58958 & -5.94184 & -2.12547 \\
\hline $\mathrm{C}$ & -2.46907 & -3.59197 & 7.81552 & $\mathrm{H}$ & 1.36397 & -0.43088 & -2.69880 \\
\hline $\mathrm{C}$ & -1.19887 & -4.08344 & 7.49063 & $\mathrm{H}$ & 1.03042 & -2.55043 & -2.09940 \\
\hline $\mathrm{C}$ & -1.00707 & -5.05000 & 6.47817 & $\mathrm{H}$ & -0.04014 & 2.63315 & 2.11258 \\
\hline $\mathrm{C}$ & -2.15217 & -5.53121 & 5.77941 & $\mathrm{H}$ & -0.33494 & 0.64148 & 3.06290 \\
\hline $\mathrm{C}$ & -3.43057 & -5.04368 & 6.12547 & $\mathrm{~N}$ & -0.27447 & -0.24678 & 3.57536 \\
\hline $\mathrm{C}$ & -3.59166 & -4.07928 & 7.12504 & $\mathrm{~N}$ & 1.83133 & 1.82285 & 2.77935 \\
\hline $\mathrm{C}$ & 0.36016 & -5.52283 & 6.14843 & $\mathrm{~N}$ & -0.11597 & 3.52994 & 1.61614 \\
\hline $\mathrm{C}$ & 0.76082 & -5.66205 & 4.78768 & $\mathrm{~N}$ & -2.20999 & 1.41559 & 2.34123 \\
\hline $\mathrm{C}$ & 2.11596 & -5.96924 & 4.46828 & $\mathrm{~N}$ & 2.72709 & -1.85317 & -1.10520 \\
\hline $\mathrm{C}$ & 3.03180 & -6.17434 & 5.52095 & $\mathrm{~N}$ & 1.79422 & 0.48283 & -2.88918 \\
\hline $\mathrm{C}$ & 2.63686 & -6.07719 & 6.86124 & $\mathrm{~N}$ & -0.40631 & -1.07856 & -3.62510 \\
\hline $\mathrm{C}$ & 1.31067 & -5.74534 & 7.16521 & $\mathrm{~N}$ & 0.59584 & -3.46748 & -1.92386 \\
\hline $\mathrm{C}$ & 2.57715 & -6.06004 & 3.05663 & $\mathrm{O}$ & -0.93574 & -7.62652 & 3.15145 \\
\hline $\mathrm{C}$ & 2.18031 & -5.10755 & 2.09160 & $\mathrm{O}$ & -2.07465 & -5.52646 & 2.57861 \\
\hline $\mathrm{C}$ & 2.66233 & -5.16724 & 0.77147 & $\mathrm{O}$ & 2.83017 & 5.66371 & -2.87649 \\
\hline $\mathrm{C}$ & 3.53511 & -6.20673 & 0.39441 & $\mathrm{O}$ & 1.94974 & 6.83590 & -4.85646 \\
\hline $\mathrm{C}$ & 3.93266 & -7.16165 & 1.34077 & $\mathrm{O}$ & -2.06155 & -6.48553 & 4.83466 \\
\hline $\mathrm{C}$ & 3.46427 & -7.08506 & 2.65928 & $\mathrm{O}$ & -0.11037 & -5.42402 & 3.79413 \\
\hline $\mathrm{C}$ & 2.26168 & -4.11115 & -0.21572 & $\mathrm{O}$ & 0.55451 & 5.97930 & -3.03051 \\
\hline $\mathrm{C}$ & 2.99591 & -2.90138 & -0.26217 & $\mathrm{O}$ & 1.99628 & 7.96203 & -2.83483 \\
\hline $\mathrm{C}$ & 3.66294 & -0.90076 & -0.81127 & $\mathrm{H}$ & 7.94991 & 5.83559 & -4.09306 \\
\hline $\mathrm{C}$ & 4.55816 & -1.35262 & 0.25433 & $\mathrm{H}$ & -6.46900 & -7.41102 & 0.37109 \\
\hline $\mathrm{C}$ & 4.13959 & -2.60627 & 0.60105 & $\mathrm{H}$ & -2.57889 & -2.81752 & 8.58538 \\
\hline $\mathrm{C}$ & 3.79238 & 0.36217 & -1.41637 & $\mathrm{H}$ & 3.20638 & 2.97574 & -8.21719 \\
\hline $\mathrm{C}$ & 2.96692 & 0.97879 & -2.36352 & $\mathrm{H}$ & -0.28238 & -9.35000 & -1.78280 \\
\hline $\mathrm{C}$ & 1.16785 & 1.44466 & -3.65487 & $\mathrm{H}$ & 1.56488 & -9.56481 & -0.07474 \\
\hline $\mathrm{C}$ & 2.03687 & 2.59258 & -3.68107 & $\mathrm{H}$ & 0.32005 & 9.31978 & 1.96918 \\
\hline $\mathrm{C}$ & 3.13290 & 2.30448 & -2.89808 & $\mathrm{H}$ & -4.11575 & 8.41148 & -3.23145 \\
\hline $\mathrm{C}$ & -0.10025 & 1.29727 & -4.26182 & $\mathrm{H}$ & 3.36456 & -6.24482 & 7.66600 \\
\hline $\mathrm{C}$ & -0.83838 & 0.07753 & -4.22937 & $\mathrm{C}$ & -5.32659 & 0.13906 & -2.52297 \\
\hline $\mathrm{C}$ & -1.39940 & -2.00000 & -3.82739 & $\mathrm{C}$ & -5.43835 & -2.24510 & -1.78265 \\
\hline $\mathrm{C}$ & -2.50520 & -1.41832 & -4.58136 & $\mathrm{C}$ & -4.11490 & -2.09928 & -1.14142 \\
\hline $\mathrm{C}$ & -2.16861 & -0.11241 & -4.81258 & $\mathrm{C}$ & -3.43804 & -0.85048 & -1.21067 \\
\hline $\mathrm{C}$ & -1.43878 & -3.32199 & -3.34530 & $\mathrm{C}$ & -4.00055 & 0.26571 & -1.88694 \\
\hline $\mathrm{C}$ & -0.55481 & -3.98193 & -2.48245 & $\mathrm{C}$ & -3.29027 & 1.46410 & -1.98326 \\
\hline C & 1.12677 & -4.35830 & -1.00953 & $\mathrm{C}$ & -2.00568 & 1.57660 & -1.41792 \\
\hline $\mathrm{C}$ & 0.27208 & -5.51281 & -0.99788 & $\mathrm{C}$ & -1.44218 & 0.50020 & -0.73283 \\
\hline $\mathrm{C}$ & -0.74584 & -5.28604 & -1.90341 & $\mathrm{C}$ & -2.14936 & -0.72424 & -0.61271 \\
\hline
\end{tabular}




\begin{tabular}{cccccccc}
$\mathrm{C}$ & -0.70470 & 2.50635 & -4.89751 & $\mathrm{C}$ & -1.57970 & -1.83709 & 0.06264 \\
$\mathrm{C}$ & -0.83112 & 3.70663 & -4.16379 & $\mathrm{C}$ & -2.25316 & -3.06034 & 0.10334 \\
$\mathrm{C}$ & -1.47447 & 4.84355 & -4.69880 & $\mathrm{C}$ & -3.52115 & -3.19065 & -0.50076 \\
$\mathrm{C}$ & -1.98550 & 4.75937 & -6.01293 & $\mathrm{C}$ & -0.07700 & 0.61621 & -0.17234 \\
$\mathrm{C}$ & -1.83122 & 3.59007 & -6.76909 & $\mathrm{C}$ & -0.27267 & -1.68036 & 0.74106 \\
$\mathrm{C}$ & -1.19175 & 2.47097 & -6.22308 & $\mathrm{H}$ & -3.73439 & 2.30366 & -2.52809 \\
$\mathrm{C}$ & -1.66529 & 6.08542 & -3.89860 & $\mathrm{H}$ & -1.43053 & 2.49854 & -1.52123 \\
$\mathrm{C}$ & -0.61981 & 6.62548 & -3.08979 & $\mathrm{H}$ & -1.79221 & -3.91599 & 0.60864 \\
$\mathrm{C}$ & -0.86163 & 7.78559 & -2.29165 & $\mathrm{H}$ & -4.05464 & -4.14641 & -0.46250 \\
$\mathrm{C}$ & -2.12144 & 8.41395 & -2.37070 & $\mathrm{O}$ & -5.91412 & 1.01373 & -3.11971 \\
$\mathrm{C}$ & -3.14106 & 7.90881 & -3.18665 & $\mathrm{O}$ & -5.94925 & -1.11071 & -2.42827 \\
$\mathrm{C}$ & -2.91189 & 6.74438 & -3.93007 & $\mathrm{O}$ & -6.11112 & -3.25085 & -1.80655 \\
$\mathrm{C}$ & 0.14744 & 8.24713 & -1.30422 & $\mathrm{O}$ & 0.65609 & 1.56508 & -0.32177 \\
$\mathrm{C}$ & 1.54014 & 8.25237 & -1.60373 & $\mathrm{O}$ & 0.38727 & -0.46613 & 0.57005 \\
$\mathrm{C}$ & 2.46699 & 8.63288 & -0.60964 & $\mathrm{O}$ & 0.25115 & -2.51787 & 1.43758 \\
\hline
\end{tabular}

Table S4. Cartesian coordinate of planar form of $\mathbf{1}_{(\mathbf{B T M A}) 2} \supset \mathbf{B T M A}^{+}$calculated by RI-DFT. \# Sum of imaginary frequencies $=0$ \# Total Energy (hartree) $=-6731.616177460$

\begin{tabular}{|c|c|c|c|c|c|c|c|}
\hline Atom & $\mathrm{x}$ & $\mathrm{y}$ & $\mathrm{z}$ & Atom & $\mathrm{x}$ & $\mathrm{y}$ & $\mathrm{z}$ \\
\hline $\mathrm{B}$ & -6.97935 & -1.80138 & -1.59781 & $\mathrm{H}$ & 7.33731 & 4.38678 & -2.83681 \\
\hline B & 6.52272 & 1.57568 & 1.89100 & $\mathrm{H}$ & 6.22720 & 3.03011 & 5.40640 \\
\hline $\mathrm{C}$ & -8.32246 & -0.11674 & -0.33167 & $\mathrm{H}$ & 5.27478 & 5.20265 & 6.21115 \\
\hline $\mathrm{C}$ & -8.26128 & -0.56017 & 1.01657 & $\mathrm{H}$ & 5.36620 & 6.68570 & 2.14986 \\
\hline $\mathrm{C}$ & -8.50560 & 0.39360 & 2.03138 & $\mathrm{H}$ & -4.75205 & -3.71626 & -5.91374 \\
\hline $\mathrm{C}$ & -8.79829 & 1.73168 & 1.74217 & $\mathrm{H}$ & -5.58433 & -6.98249 & -3.20037 \\
\hline $\mathrm{C}$ & -8.85881 & 2.15110 & 0.40419 & $\mathrm{H}$ & -7.04208 & -5.45509 & -1.84571 \\
\hline $\mathrm{C}$ & -8.62722 & 1.22784 & -0.62133 & $\mathrm{H}$ & -6.42291 & 1.93428 & -5.76989 \\
\hline $\mathrm{C}$ & -7.95303 & -1.96821 & 1.37397 & $\mathrm{H}$ & -6.43918 & -2.26650 & -6.76328 \\
\hline $\mathrm{C}$ & -6.94377 & -2.70874 & 0.68950 & $\mathrm{H}$ & -4.55878 & 0.85373 & -1.89768 \\
\hline $\mathrm{C}$ & -6.56506 & -4.00160 & 1.15922 & $\mathrm{H}$ & -5.84481 & 4.80968 & -0.70406 \\
\hline $\mathrm{C}$ & -7.23594 & -4.53803 & 2.27985 & $\mathrm{H}$ & -7.70768 & 2.86033 & -4.08453 \\
\hline $\mathrm{C}$ & -8.25982 & -3.83879 & 2.92701 & $\mathrm{H}$ & -5.63527 & -0.35698 & 2.82319 \\
\hline $\mathrm{C}$ & -8.60706 & -2.56226 & 2.47474 & $\mathrm{H}$ & -6.07709 & 0.90472 & 0.46772 \\
\hline $\mathrm{C}$ & -5.49305 & -4.81120 & 0.51541 & $\mathrm{H}$ & -3.73418 & -0.30415 & 4.59395 \\
\hline $\mathrm{C}$ & -4.28013 & -4.24564 & 0.06493 & $\mathrm{H}$ & -1.14040 & 2.31792 & 3.29080 \\
\hline $\mathrm{C}$ & -3.25714 & -5.04207 & -0.48874 & $\mathrm{H}$ & 0.93473 & 0.05032 & 6.23027 \\
\hline $\mathrm{C}$ & -3.45720 & -6.43252 & -0.61487 & $\mathrm{H}$ & -1.64509 & -0.81034 & 6.16737 \\
\hline $\mathrm{C}$ & -4.65439 & -7.00903 & -0.17375 & $\mathrm{H}$ & 2.83360 & 5.72354 & 1.60729 \\
\hline $\mathrm{C}$ & -5.65724 & -6.21000 & 0.38721 & $\mathrm{H}$ & 3.60160 & 3.90543 & 3.47845 \\
\hline $\mathrm{C}$ & -1.96332 & -4.43197 & -0.92908 & $\mathrm{H}$ & 0.66504 & 6.12441 & 0.25290 \\
\hline $\mathrm{C}$ & -2.01255 & -3.49508 & -1.98487 & $\mathrm{H}$ & -1.88955 & 3.45351 & 1.50856 \\
\hline $\mathrm{C}$ & -1.34045 & -1.96165 & -3.51664 & $\mathrm{H}$ & -3.47449 & 4.91670 & -2.16000 \\
\hline
\end{tabular}




\begin{tabular}{|c|c|c|c|c|c|c|c|}
\hline $\mathrm{C}$ & -2.77142 & -2.07572 & -3.59542 & $\mathrm{H}$ & -1.21432 & 6.31248 & -1.59620 \\
\hline $\mathrm{C}$ & -3.18076 & -3.00412 & -2.66100 & $\mathrm{H}$ & 3.53417 & 0.64382 & 3.42382 \\
\hline $\mathrm{C}$ & -0.54134 & -1.06651 & -4.24096 & $\mathrm{H}$ & 5.82021 & 0.84110 & 7.09441 \\
\hline $\mathrm{C}$ & 0.82509 & -0.77658 & -4.07863 & $\mathrm{H}$ & 4.11186 & 2.33245 & 8.09068 \\
\hline $\mathrm{C}$ & 2.85260 & -0.66807 & -3.28269 & $\mathrm{H}$ & 2.07843 & 2.97397 & 6.76755 \\
\hline $\mathrm{C}$ & 2.77239 & 0.34912 & -4.33154 & $\mathrm{H}$ & 8.70499 & -2.78453 & 3.59028 \\
\hline $\mathrm{C}$ & 1.50512 & 0.27237 & -4.83609 & $\mathrm{H}$ & 6.01973 & -1.28967 & 6.61276 \\
\hline $\mathrm{C}$ & 3.98819 & -0.87082 & -2.45982 & $\mathrm{H}$ & 8.71176 & 0.76117 & -1.06015 \\
\hline $\mathrm{C}$ & 4.05667 & -1.83471 & -1.43586 & $\mathrm{H}$ & 9.26524 & -1.44147 & -2.12127 \\
\hline $\mathrm{C}$ & 3.44861 & -3.52826 & -0.05610 & $\mathrm{H}$ & 8.00097 & -3.45395 & 1.49360 \\
\hline $\mathrm{C}$ & 4.76139 & -3.08101 & 0.33152 & $\mathrm{~N}$ & -0.92369 & -2.84365 & -2.53888 \\
\hline $\mathrm{C}$ & 5.12898 & -2.04740 & -0.50475 & $\mathrm{~N}$ & 1.66419 & -1.34478 & -3.15730 \\
\hline $\mathrm{C}$ & 2.67584 & -4.50231 & 0.58967 & $\mathrm{~N}$ & 3.06988 & -2.75312 & -1.13349 \\
\hline $\mathrm{C}$ & 1.32435 & -4.83960 & 0.38677 & $\mathrm{~N}$ & 0.47464 & -4.27371 & -0.52951 \\
\hline $\mathrm{C}$ & -0.76413 & -4.80519 & -0.26276 & $\mathrm{~N}$ & -3.21512 & 1.85657 & 1.99509 \\
\hline $\mathrm{C}$ & -0.69616 & -5.74901 & 0.85274 & $\mathrm{~N}$ & -0.97039 & 1.61077 & 4.01883 \\
\hline $\mathrm{C}$ & 0.61364 & -5.78016 & 1.24633 & $\mathrm{~N}$ & 0.36195 & 3.62205 & 2.55420 \\
\hline $\mathrm{C}$ & 5.17553 & 0.02310 & -2.65020 & $\mathrm{~N}$ & -1.98872 & 4.02292 & 0.65878 \\
\hline $\mathrm{C}$ & 5.38367 & 1.10052 & -1.76891 & $\mathrm{O}$ & -8.18489 & -0.97609 & -1.37043 \\
\hline $\mathrm{C}$ & 6.42795 & 2.02936 & -1.97331 & $\mathrm{O}$ & -6.28466 & -2.17048 & -0.36331 \\
\hline $\mathrm{C}$ & 7.30400 & 1.79320 & -3.06207 & $\mathrm{O}$ & 5.72042 & 2.26085 & 0.88218 \\
\hline $\mathrm{C}$ & 7.12869 & 0.70137 & -3.91942 & $\mathrm{O}$ & 6.93657 & 2.46679 & 3.00829 \\
\hline $\mathrm{C}$ & 6.05640 & -0.18109 & -3.72872 & $\mathrm{O}$ & -7.52132 & -2.96194 & -2.35000 \\
\hline $\mathrm{C}$ & 6.60772 & 3.25184 & -1.13859 & $\mathrm{O}$ & -5.95656 & -1.07567 & -2.38045 \\
\hline $\mathrm{C}$ & 6.28000 & 3.32734 & 0.24891 & $\mathrm{O}$ & 5.71663 & 0.45773 & 2.39796 \\
\hline $\mathrm{C}$ & 6.49730 & 4.53483 & 0.97248 & $\mathrm{O}$ & 7.82672 & 1.11619 & 1.33967 \\
\hline $\mathrm{C}$ & 7.06223 & 5.64383 & 0.30958 & $\mathrm{H}$ & -8.77273 & -4.28082 & 3.78938 \\
\hline $\mathrm{C}$ & 7.37436 & 5.58854 & -1.05097 & $\mathrm{H}$ & -8.95894 & 2.44571 & 2.55855 \\
\hline $\mathrm{C}$ & 7.13184 & 4.41011 & -1.76055 & $\mathrm{H}$ & 7.79795 & 6.46264 & -1.55961 \\
\hline $\mathrm{C}$ & 6.11087 & 4.66952 & 2.39896 & $\mathrm{H}$ & 8.90662 & -3.56796 & -0.81850 \\
\hline $\mathrm{C}$ & 6.32938 & 3.63303 & 3.34507 & $\mathrm{H}$ & 4.83173 & 7.04630 & 4.54895 \\
\hline $\mathrm{C}$ & 6.04090 & 3.84961 & 4.70665 & $\mathrm{H}$ & 7.85507 & -2.82612 & 5.94389 \\
\hline $\mathrm{C}$ & 5.51128 & 5.06661 & 5.14863 & $\mathrm{H}$ & -7.52809 & 4.81414 & -2.55687 \\
\hline $\mathrm{C}$ & 5.26738 & 6.09438 & 4.22404 & $\mathrm{H}$ & -6.59506 & 0.12688 & -7.47788 \\
\hline $\mathrm{C}$ & 5.56920 & 5.88685 & 2.87329 & $\mathrm{H}$ & -4.43841 & -6.09824 & -5.26051 \\
\hline $\mathrm{C}$ & -6.70009 & -3.74376 & -3.09822 & $\mathrm{C}$ & 10.69340 & 3.64096 & 2.37988 \\
\hline $\mathrm{C}$ & -6.06981 & -3.23360 & -4.26434 & $\mathrm{C}$ & 10.23250 & 3.36537 & 1.07440 \\
\hline $\mathrm{C}$ & -5.27284 & -4.11110 & -5.03230 & $\mathrm{C}$ & 10.96593 & 3.80004 & -0.03751 \\
\hline $\mathrm{C}$ & -5.08885 & -5.44856 & -4.66277 & $\mathrm{C}$ & 12.16250 & 4.51211 & 0.13980 \\
\hline $\mathrm{C}$ & -5.72474 & -5.94030 & -3.51094 & $\mathrm{C}$ & 12.61964 & 4.80477 & 1.43485 \\
\hline $\mathrm{C}$ & -6.53324 & -5.09440 & -2.74383 & $\mathrm{C}$ & 11.88427 & 4.37745 & 2.54936 \\
\hline $\mathrm{C}$ & -6.22608 & -1.81270 & -4.65835 & $\mathrm{C}$ & 9.86328 & 3.19419 & 3.55284 \\
\hline $\mathrm{C}$ & -6.15781 & -0.77603 & -3.67892 & $\mathrm{C}$ & 11.56479 & 1.93112 & 4.92141 \\
\hline
\end{tabular}




\begin{tabular}{|c|c|c|c|c|c|c|c|}
\hline $\mathrm{C}$ & -6.23178 & 0.59032 & -4.08159 & $\mathrm{C}$ & 10.40348 & 0.77416 & 3.08561 \\
\hline $\mathrm{C}$ & -6.39379 & 0.88423 & -5.45402 & $\mathrm{C}$ & 9.15543 & 1.40156 & 5.10660 \\
\hline $\mathrm{C}$ & -6.47875 & -0.12766 & -6.41757 & $\mathrm{H}$ & 9.29314 & 2.81431 & 0.93622 \\
\hline $\mathrm{C}$ & -6.38617 & -1.46526 & -6.01568 & $\mathrm{H}$ & 10.58958 & 3.59026 & -1.04572 \\
\hline $\mathrm{C}$ & -6.13864 & 1.71484 & -3.10953 & $\mathrm{H}$ & 12.73437 & 4.85411 & -0.73151 \\
\hline $\mathrm{C}$ & -5.20925 & 1.72151 & -2.04541 & $\mathrm{H}$ & 13.54221 & 5.38036 & 1.57652 \\
\hline $\mathrm{C}$ & -5.07982 & 2.83677 & -1.19349 & $\mathrm{H}$ & 12.22784 & 4.64268 & 3.55854 \\
\hline $\mathrm{C}$ & -5.92477 & 3.95120 & -1.38167 & $\mathrm{H}$ & 9.91120 & 3.90214 & 4.39888 \\
\hline $\mathrm{C}$ & -6.86352 & 3.95190 & -2.42006 & $\mathrm{H}$ & 8.81295 & 3.04019 & 3.25165 \\
\hline $\mathrm{C}$ & -6.96189 & 2.85139 & -3.27965 & $\mathrm{H}$ & 11.44475 & 2.67082 & 5.73070 \\
\hline $\mathrm{C}$ & -4.03594 & 2.86758 & -0.12149 & $\mathrm{H}$ & 11.81624 & 0.94343 & 5.34310 \\
\hline $\mathrm{C}$ & -4.11797 & 1.94985 & 0.95871 & $\mathrm{H}$ & 12.34979 & 2.25636 & 4.21989 \\
\hline $\mathrm{C}$ & -3.75000 & 0.92407 & 2.85220 & $\mathrm{H}$ & 9.46804 & 0.78250 & 2.50418 \\
\hline $\mathrm{C}$ & -5.01228 & 0.39954 & 2.33934 & $\mathrm{H}$ & 11.25884 & 1.03982 & 2.44564 \\
\hline $\mathrm{C}$ & -5.23534 & 1.03007 & 1.14779 & $\mathrm{H}$ & 10.55876 & -0.20431 & 3.56899 \\
\hline $\mathrm{C}$ & -3.16193 & 0.44834 & 4.03957 & $\mathrm{H}$ & 9.04704 & 2.17862 & 5.88140 \\
\hline $\mathrm{C}$ & -1.87937 & 0.71580 & 4.54095 & $\mathrm{H}$ & 9.41642 & 0.43048 & 5.55866 \\
\hline $\mathrm{C}$ & 0.26618 & 1.45363 & 4.61466 & $\mathrm{~N}$ & 10.27018 & 1.81775 & 4.16978 \\
\hline $\mathrm{C}$ & 0.12427 & 0.40975 & 5.59473 & $\mathrm{H}$ & 8.22463 & 1.32128 & 4.51984 \\
\hline $\mathrm{C}$ & -1.18824 & -0.02214 & 5.56496 & $\mathrm{C}$ & -10.31731 & -3.89239 & -5.01833 \\
\hline $\mathrm{C}$ & 1.42373 & 2.18453 & 4.27060 & $\mathrm{C}$ & -9.33048 & -3.71400 & -6.00849 \\
\hline $\mathrm{C}$ & 1.43963 & 3.22604 & 3.31081 & $\mathrm{C}$ & -8.40571 & -4.73020 & -6.27870 \\
\hline $\mathrm{C}$ & 0.82563 & 4.66149 & 1.79168 & $\mathrm{C}$ & -8.46137 & -5.93788 & -5.56950 \\
\hline $\mathrm{C}$ & 2.22956 & 4.94860 & 2.08492 & $\mathrm{C}$ & -9.45004 & -6.13169 & -4.59345 \\
\hline $\mathrm{C}$ & 2.62090 & 4.03528 & 3.02093 & $\mathrm{C}$ & -10.37584 & -5.11735 & -4.32283 \\
\hline $\mathrm{C}$ & 0.12631 & 5.31971 & 0.76524 & $\mathrm{C}$ & -11.29853 & -2.79246 & -4.71054 \\
\hline $\mathrm{C}$ & -1.12321 & 5.00045 & 0.21862 & $\mathrm{C}$ & -10.58014 & -2.56562 & -2.30777 \\
\hline $\mathrm{C}$ & -3.02749 & 3.85232 & -0.23436 & $\mathrm{C}$ & -9.57150 & -1.10042 & -4.04146 \\
\hline $\mathrm{C}$ & -2.82533 & 4.81190 & -1.28975 & $\mathrm{C}$ & -11.91763 & -0.79641 & -3.37081 \\
\hline $\mathrm{C}$ & -1.67756 & 5.52248 & -1.00143 & $\mathrm{H}$ & -9.27880 & -2.77133 & -6.56761 \\
\hline $\mathrm{C}$ & 2.67825 & 1.83999 & 5.01825 & $\mathrm{H}$ & -7.63439 & -4.57792 & -7.04121 \\
\hline $\mathrm{C}$ & 3.66101 & 1.00609 & 4.44828 & $\mathrm{H}$ & -7.72730 & -6.72470 & -5.77257 \\
\hline $\mathrm{C}$ & 4.79689 & 0.60573 & 5.18863 & $\mathrm{H}$ & -9.49829 & -7.07609 & -4.03931 \\
\hline $\mathrm{C}$ & 4.93144 & 1.10282 & 6.50773 & $\mathrm{H}$ & -11.15252 & -5.27953 & -3.56476 \\
\hline $\mathrm{C}$ & 3.97304 & 1.95138 & 7.07128 & $\mathrm{H}$ & -11.48424 & -2.15449 & -5.59219 \\
\hline $\mathrm{C}$ & 2.84098 & 2.31676 & 6.33347 & $\mathrm{H}$ & -12.26196 & -3.19482 & -4.35183 \\
\hline $\mathrm{C}$ & 5.82777 & -0.34035 & 4.67370 & $\mathrm{H}$ & -9.79661 & -0.53304 & -4.95992 \\
\hline $\mathrm{C}$ & 6.28594 & -0.35384 & 3.32114 & $\mathrm{H}$ & -9.23246 & -0.45338 & -3.21901 \\
\hline $\mathrm{C}$ & 7.33089 & -1.24534 & 2.93287 & $\mathrm{H}$ & -8.79116 & -1.85242 & -4.22083 \\
\hline $\mathrm{C}$ & 7.89205 & -2.11322 & 3.89330 & $\mathrm{H}$ & -12.13007 & -0.27795 & -4.32096 \\
\hline $\mathrm{C}$ & 7.42899 & -2.12855 & 5.21276 & $\mathrm{H}$ & -11.56212 & -0.07677 & -2.61505 \\
\hline $\mathrm{C}$ & 6.40373 & -1.25475 & 5.58664 & $\mathrm{~N}$ & -10.83127 & -1.81394 & -3.60063 \\
\hline $\mathrm{C}$ & 7.82086 & -1.29499 & 1.53336 & $\mathrm{H}$ & -12.82186 & -1.31331 & -3.00832 \\
\hline
\end{tabular}




\begin{tabular}{cccccccc}
$\mathrm{C}$ & 8.01668 & -0.10652 & 0.77946 & $\mathrm{H}$ & -10.36821 & -1.82770 & -1.52171 \\
$\mathrm{C}$ & 8.55477 & -0.17532 & -0.51903 & $\mathrm{H}$ & -11.48278 & -3.15792 & -2.08056 \\
$\mathrm{C}$ & 8.87129 & -1.40885 & -1.09842 & $\mathrm{H}$ & -9.68344 & -3.19213 & -2.43259 \\
$\mathrm{C}$ & 8.67567 & -2.59450 & -0.37061 & $\mathrm{C}$ & 0.59452 & 1.84084 & -0.24027 \\
$\mathrm{C}$ & 8.16586 & -2.52671 & 0.93113 & $\mathrm{C}$ & -0.14202 & 2.26226 & -1.36659 \\
$\mathrm{H}$ & -8.42980 & 0.07761 & 3.07885 & $\mathrm{C}$ & 0.47121 & 3.01137 & -2.37820 \\
$\mathrm{H}$ & -9.06846 & 3.19887 & 0.15564 & $\mathrm{C}$ & 1.81853 & 3.38392 & -2.25958 \\
$\mathrm{H}$ & -8.64687 & 1.53645 & -1.67122 & $\mathrm{C}$ & 2.55170 & 2.99825 & -1.12853 \\
$\mathrm{H}$ & -6.92873 & -5.52008 & 2.65920 & $\mathrm{C}$ & 1.94965 & 2.21441 & -0.13526 \\
$\mathrm{H}$ & -9.40309 & -2.00284 & 2.98108 & $\mathrm{C}$ & -0.05268 & 1.08585 & 0.89282 \\
$\mathrm{H}$ & -4.12726 & -3.16625 & 0.16594 & $\mathrm{C}$ & -1.50504 & -0.54290 & -0.35063 \\
$\mathrm{H}$ & -2.67420 & -7.05190 & -1.06766 & $\mathrm{C}$ & -0.73565 & -1.07019 & 1.90448 \\
$\mathrm{H}$ & -4.81320 & -8.08937 & -0.28090 & $\mathrm{C}$ & 0.87988 & -1.07731 & 0.06205 \\
$\mathrm{H}$ & -6.59939 & -6.67232 & 0.70598 & $\mathrm{H}$ & -1.21216 & 2.03730 & -1.44455 \\
$\mathrm{H}$ & 0.04211 & -3.01158 & -2.23535 & $\mathrm{H}$ & -0.11611 & 3.32572 & -3.24894 \\
$\mathrm{H}$ & -3.40370 & -1.50116 & -4.27577 & $\mathrm{H}$ & 2.29602 & 3.98368 & -3.04377 \\
$\mathrm{H}$ & -4.19981 & -3.31529 & -2.43989 & $\mathrm{H}$ & 3.59438 & 3.31271 & -1.01231 \\
$\mathrm{H}$ & -1.07698 & -0.47872 & -4.99575 & $\mathrm{H}$ & 2.53587 & 1.92867 & 0.74771 \\
$\mathrm{H}$ & 3.57797 & 1.02828 & -4.61691 & $\mathrm{H}$ & 0.60891 & 1.08091 & 1.77169 \\
$\mathrm{H}$ & 1.05191 & 0.87661 & -5.62693 & $\mathrm{H}$ & -1.02569 & 1.51107 & 1.18668 \\
$\mathrm{H}$ & 2.19898 & -2.82218 & -1.67259 & $\mathrm{H}$ & -2.33882 & 0.07584 & 0.02111 \\
$\mathrm{H}$ & 5.32998 & -3.48826 & 1.16960 & $\mathrm{H}$ & -1.18156 & -0.21355 & -1.34880 \\
$\mathrm{H}$ & 6.04448 & -1.45789 & -0.48360 & $\mathrm{H}$ & -1.80003 & -1.60253 & -0.38650 \\
$\mathrm{H}$ & 3.18527 & -5.02646 & 1.40643 & $\mathrm{H}$ & -0.91437 & -2.13964 & 1.70094 \\
$\mathrm{H}$ & -1.53993 & -6.29704 & 1.27559 & $\mathrm{H}$ & 0.08821 & -0.94882 & 2.62649 \\
$\mathrm{H}$ & 1.06278 & -6.36329 & 2.05503 & $\mathrm{H}$ & -1.64854 & -0.58934 & 2.28511 \\
$\mathrm{H}$ & 4.70545 & 1.22664 & -0.92441 & $\mathrm{H}$ & 1.70565 & -0.92478 & 0.77682 \\
$\mathrm{H}$ & 8.15762 & 2.46125 & -3.22579 & $\mathrm{H}$ & 1.12968 & -0.63482 & -0.91443 \\
$\mathrm{H}$ & 7.83285 & 0.53942 & -4.74488 & $\mathrm{~N}$ & -0.34824 & -0.40334 & 0.60844 \\
$\mathrm{H}$ & 5.89914 & -1.02770 & -4.40686 & $\mathrm{H}$ & 0.65904 & -2.15183 & -0.05864 \\
$\mathrm{H}$ & 7.26280 & 6.55870 & 0.87952 & & & & \\
\hline & & & & & & & \\
\hline
\end{tabular}

Table S5. Cartesian coordinate of packman form of $\mathbf{1}_{\text {(BTMA)2 }} \supset$ BTMA $^{+}$calculated by RI-DFT. \# Sum of imaginary frequencies $=0$

\# Total Energy (hartree) $=-6731.618287706$

\begin{tabular}{|c|c|c|c|c|c|c|c|}
\hline Atom & $\mathrm{x}$ & $\mathrm{y}$ & $\mathrm{Z}$ & Atom & $\mathrm{X}$ & $\mathrm{y}$ & $\mathrm{Z}$ \\
\hline $\mathrm{B}$ & -5.84409 & -3.67628 & -3.18730 & $\mathrm{H}$ & -9.20654 & 0.82335 & -4.16784 \\
\hline B & 5.91313 & 3.83749 & 1.82426 & $\mathrm{H}$ & -8.04676 & -1.25383 & -4.97478 \\
\hline $\mathrm{C}$ & -7.71199 & -2.03485 & -3.00336 & $\mathrm{H}$ & -6.50382 & -5.51630 & 2.11301 \\
\hline $\mathrm{C}$ & -7.90024 & -1.85995 & -1.60662 & $\mathrm{H}$ & -9.32960 & -2.67291 & 0.51567 \\
\hline $\mathrm{C}$ & -8.55710 & -0.68725 & -1.16747 & $\mathrm{H}$ & -3.41383 & -3.73262 & -0.45719 \\
\hline $\mathrm{C}$ & -9.03261 & 0.27299 & -2.06815 & $\mathrm{H}$ & -1.36787 & -7.51340 & 0.02506 \\
\hline $\mathrm{C}$ & -8.84840 & 0.07780 & -3.44767 & $\mathrm{H}$ & -3.52245 & -8.57406 & 0.72059 \\
\hline
\end{tabular}




\begin{tabular}{|c|c|c|c|c|c|c|c|}
\hline $\mathrm{C}$ & -8.19373 & -1.06954 & -3.90703 & $\mathrm{H}$ & -5.61139 & -7.22626 & 0.81300 \\
\hline $\mathrm{C}$ & -7.51204 & -2.91377 & -0.63538 & $\mathrm{H}$ & 1.02632 & -3.23753 & -1.58813 \\
\hline $\mathrm{C}$ & -6.28289 & -3.63090 & -0.75612 & $\mathrm{H}$ & -1.94318 & -2.82078 & -4.65474 \\
\hline $\mathrm{C}$ & -5.91928 & -4.58135 & 0.24956 & $\mathrm{H}$ & -2.84845 & -4.53553 & -2.79114 \\
\hline $\mathrm{C}$ & -6.79942 & -4.80563 & 1.33158 & $\mathrm{H}$ & 0.22334 & -1.32575 & -4.91774 \\
\hline $\mathrm{C}$ & -8.02580 & -4.13845 & 1.42969 & $\mathrm{H}$ & 4.51342 & 0.86122 & -3.99507 \\
\hline $\mathrm{C}$ & -8.36996 & -3.20025 & 0.44969 & $\mathrm{H}$ & 2.23515 & 0.24639 & -5.35386 \\
\hline $\mathrm{C}$ & -4.66307 & -5.37522 & 0.17660 & $\mathrm{H}$ & 2.93336 & -2.54028 & -0.67792 \\
\hline $\mathrm{C}$ & -3.43549 & -4.79619 & -0.20117 & $\mathrm{H}$ & 5.89757 & -2.92641 & 2.38686 \\
\hline $\mathrm{C}$ & -2.23818 & -5.54082 & -0.23405 & $\mathrm{H}$ & 6.72606 & -1.08042 & 0.58104 \\
\hline $\mathrm{C}$ & -2.28307 & -6.91418 & 0.08804 & $\mathrm{H}$ & 3.68749 & -4.35484 & 2.70125 \\
\hline $\mathrm{C}$ & -3.49209 & -7.50525 & 0.47523 & $\mathrm{H}$ & -0.81310 & -6.13721 & 2.07237 \\
\hline $\mathrm{C}$ & -4.66716 & -6.74453 & 0.52858 & $\mathrm{H}$ & 1.56013 & -5.67167 & 3.29711 \\
\hline $\mathrm{C}$ & -0.95154 & -4.85561 & -0.55688 & $\mathrm{H}$ & 4.80587 & 2.00023 & -1.25166 \\
\hline $\mathrm{C}$ & -0.89111 & -4.11971 & -1.76237 & $\mathrm{H}$ & 8.92958 & 2.64881 & -2.37447 \\
\hline $\mathrm{C}$ & -0.12507 & -2.67769 & -3.33760 & $\mathrm{H}$ & 9.22748 & 0.19685 & -2.69495 \\
\hline $\mathrm{C}$ & -1.42792 & -3.13428 & -3.74458 & $\mathrm{H}$ & 7.31346 & -1.36717 & -2.28710 \\
\hline $\mathrm{C}$ & -1.89499 & -4.01058 & -2.78781 & $\mathrm{H}$ & 6.09482 & 7.84212 & -1.44073 \\
\hline $\mathrm{C}$ & 0.64708 & -1.70196 & -3.97987 & $\mathrm{H}$ & 7.70091 & 4.39039 & -3.47921 \\
\hline $\mathrm{C}$ & 1.86717 & -1.12815 & -3.57721 & $\mathrm{H}$ & 4.26944 & 6.40127 & 3.94912 \\
\hline $\mathrm{C}$ & 3.69680 & -0.64225 & -2.49142 & $\mathrm{H}$ & 2.56967 & 8.12343 & 3.33367 \\
\hline $\mathrm{C}$ & 3.71436 & 0.17631 & -3.70434 & $\mathrm{H}$ & 3.78131 & 7.78079 & -0.80668 \\
\hline $\mathrm{C}$ & 2.56925 & -0.13181 & -4.38385 & $\mathrm{H}$ & -2.43013 & -6.31658 & -6.09220 \\
\hline $\mathrm{C}$ & 4.76438 & -0.69019 & -1.55981 & $\mathrm{H}$ & -3.21424 & -8.64201 & -2.52850 \\
\hline $\mathrm{C}$ & 4.79564 & -1.56503 & -0.45528 & $\mathrm{H}$ & -5.14016 & -7.14413 & -2.00338 \\
\hline $\mathrm{C}$ & 4.09220 & -3.08960 & 1.06125 & $\mathrm{H}$ & -5.03097 & -1.58360 & -8.32468 \\
\hline $\mathrm{C}$ & 5.38406 & -2.60725 & 1.47713 & $\mathrm{H}$ & -4.17978 & -5.75823 & -7.62649 \\
\hline $\mathrm{C}$ & 5.81199 & -1.67447 & 0.55593 & $\mathrm{H}$ & -3.78584 & -0.84773 & -4.15769 \\
\hline $\mathrm{C}$ & 3.27535 & -3.99267 & 1.75223 & $\mathrm{H}$ & -5.84636 & 2.92377 & -4.63503 \\
\hline $\mathrm{C}$ & 1.99769 & -4.47349 & 1.41358 & $\mathrm{H}$ & -6.75591 & -0.38855 & -7.26826 \\
\hline $\mathrm{C}$ & 0.10303 & -4.87888 & 0.40033 & $\mathrm{H}$ & -6.99753 & 2.13109 & 0.22283 \\
\hline $\mathrm{C}$ & 0.03403 & -5.56353 & 1.69312 & $\mathrm{H}$ & -6.61838 & 1.32672 & -2.34319 \\
\hline $\mathrm{C}$ & 1.22815 & -5.32476 & 2.31455 & $\mathrm{H}$ & -5.42499 & 2.96872 & 2.11062 \\
\hline $\mathrm{C}$ & 5.93328 & 0.22209 & -1.75115 & $\mathrm{H}$ & -1.92543 & 3.51849 & 0.45564 \\
\hline $\mathrm{C}$ & 5.77885 & 1.60730 & -1.56135 & $\mathrm{H}$ & -1.29633 & 3.94151 & 4.64344 \\
\hline $\mathrm{C}$ & 6.84691 & 2.50234 & -1.77824 & $\mathrm{H}$ & -3.92755 & 3.43421 & 4.23262 \\
\hline $\mathrm{C}$ & 8.08406 & 1.97109 & -2.20427 & $\mathrm{H}$ & 3.21077 & 4.08668 & -1.44896 \\
\hline $\mathrm{C}$ & 8.25450 & 0.59118 & -2.37631 & $\mathrm{H}$ & 2.89132 & 4.70085 & 1.16106 \\
\hline $\mathrm{C}$ & 7.18826 & -0.28716 & -2.14384 & $\mathrm{H}$ & 1.70892 & 2.98180 & -3.26051 \\
\hline $\mathrm{C}$ & 6.66397 & 3.97006 & -1.62730 & $\mathrm{H}$ & -1.85132 & 2.74950 & -1.66638 \\
\hline $\mathrm{C}$ & 5.96624 & 4.53689 & -0.52323 & $\mathrm{H}$ & -2.26879 & 1.16869 & -5.59396 \\
\hline $\mathrm{C}$ & 5.73276 & 5.93931 & -0.47718 & $\mathrm{H}$ & 0.32575 & 1.90962 & -5.24878 \\
\hline $\mathrm{C}$ & 6.26117 & 6.75916 & -1.49505 & $\mathrm{H}$ & 2.49694 & 2.79132 & 2.84216 \\
\hline
\end{tabular}




\begin{tabular}{|c|c|c|c|c|c|c|c|}
\hline $\mathrm{C}$ & 6.99064 & 6.21538 & -2.55757 & $\mathrm{H}$ & 3.38242 & 5.15152 & 6.35496 \\
\hline $\mathrm{C}$ & 7.17323 & 4.82999 & -2.62374 & $\mathrm{H}$ & 1.37329 & 6.55628 & 5.91829 \\
\hline $\mathrm{C}$ & 4.87131 & 6.52627 & 0.57723 & $\mathrm{H}$ & -0.06651 & 6.10306 & 3.92678 \\
\hline $\mathrm{C}$ & 4.98581 & 6.13312 & 1.93518 & $\mathrm{H}$ & 7.41779 & 0.86413 & 5.80848 \\
\hline $\mathrm{C}$ & 4.16663 & 6.72750 & 2.91074 & $\mathrm{H}$ & 3.82112 & 2.92821 & 7.01116 \\
\hline $\mathrm{C}$ & 3.21416 & 7.69111 & 2.55875 & $\mathrm{H}$ & 8.91065 & 2.25792 & 0.33829 \\
\hline $\mathrm{C}$ & 3.07580 & 8.07755 & 1.21723 & $\mathrm{H}$ & 9.77599 & -0.09487 & 0.50740 \\
\hline $\mathrm{C}$ & 3.90188 & 7.49814 & 0.24631 & $\mathrm{H}$ & 7.37585 & -0.67360 & 4.06230 \\
\hline $\mathrm{C}$ & -4.87926 & -5.90020 & -3.74226 & $\mathrm{~N}$ & 0.16640 & -3.31636 & -2.14722 \\
\hline $\mathrm{C}$ & -4.12848 & -5.66293 & -4.92344 & $\mathrm{~N}$ & 2.56113 & -1.41336 & -2.43134 \\
\hline $\mathrm{C}$ & -3.03851 & -6.51680 & -5.20177 & $\mathrm{~N}$ & 3.78949 & -2.44457 & -0.11660 \\
\hline $\mathrm{C}$ & -2.69971 & -7.58212 & -4.35884 & $\mathrm{~N}$ & 1.29529 & -4.20992 & 0.26473 \\
\hline $\mathrm{C}$ & -3.46619 & -7.81882 & -3.20787 & $\mathrm{~N}$ & -3.83015 & 2.55724 & -0.87868 \\
\hline $\mathrm{C}$ & -4.54880 & -6.98336 & -2.90842 & $\mathrm{~N}$ & -2.12831 & 3.57214 & 1.46189 \\
\hline $\mathrm{C}$ & -4.46445 & -4.55537 & -5.85009 & $\mathrm{~N}$ & 0.09709 & 3.45667 & -0.28501 \\
\hline $\mathrm{C}$ & -4.77715 & -3.26350 & -5.34582 & $\mathrm{~N}$ & -1.58720 & 2.40072 & -2.59723 \\
\hline $\mathrm{C}$ & -4.97563 & -2.17666 & -6.24307 & $\mathrm{~N}$ & -1.11292 & -0.46238 & 0.55872 \\
\hline $\mathrm{C}$ & -4.89880 & -2.42326 & -7.63131 & $\mathrm{O}$ & -7.20098 & -3.18822 & -3.50369 \\
\hline $\mathrm{C}$ & -4.62755 & -3.69973 & -8.13509 & $\mathrm{O}$ & -5.44336 & -3.39429 & -1.78608 \\
\hline $\mathrm{C}$ & -4.40347 & -4.75467 & -7.24422 & $\mathrm{O}$ & 5.45769 & 3.72718 & 0.44037 \\
\hline $\mathrm{C}$ & -5.23552 & -0.79153 & -5.76987 & $\mathrm{O}$ & 5.93551 & 5.23543 & 2.32863 \\
\hline $\mathrm{C}$ & -4.51826 & -0.23422 & -4.69070 & $\mathrm{O}$ & -5.97009 & -5.14133 & -3.43326 \\
\hline $\mathrm{C}$ & -4.71996 & 1.09861 & -4.28902 & $\mathrm{O}$ & -4.80880 & -3.05007 & -4.00469 \\
\hline $\mathrm{C}$ & -5.68308 & 1.88685 & -4.95181 & $\mathrm{O}$ & 4.96384 & 3.00653 & 2.60152 \\
\hline $\mathrm{C}$ & -6.40467 & 1.34594 & -6.02349 & $\mathrm{O}$ & 7.31690 & 3.41177 & 2.00630 \\
\hline $\mathrm{C}$ & -6.17571 & 0.02694 & -6.43519 & $\mathrm{H}$ & -8.70446 & -4.34003 & 2.26675 \\
\hline $\mathrm{C}$ & -3.88097 & 1.68329 & -3.19870 & $\mathrm{H}$ & -9.52826 & 1.17716 & -1.69489 \\
\hline $\mathrm{C}$ & -4.48595 & 2.02465 & -1.96405 & $\mathrm{H}$ & 7.39771 & 6.86533 & -3.34122 \\
\hline $\mathrm{C}$ & -4.78178 & 2.64481 & 0.10698 & $\mathrm{H}$ & 9.00189 & -1.56363 & 2.40048 \\
\hline $\mathrm{C}$ & -6.07961 & 2.17418 & -0.36962 & $\mathrm{H}$ & 2.32088 & 8.81726 & 0.92521 \\
\hline $\mathrm{C}$ & -5.89313 & 1.77556 & -1.66297 & $\mathrm{H}$ & 5.84009 & 1.58261 & 7.61171 \\
\hline $\mathrm{C}$ & -4.55638 & 3.01619 & 1.44345 & $\mathrm{H}$ & -7.15044 & 1.95858 & -6.54513 \\
\hline $\mathrm{C}$ & -3.35286 & 3.37475 & 2.06726 & $\mathrm{H}$ & -4.57480 & -3.86701 & -9.21750 \\
\hline $\mathrm{C}$ & -1.15267 & 3.83994 & 2.40546 & $\mathrm{H}$ & -1.83666 & -8.21608 & -4.59424 \\
\hline $\mathrm{C}$ & -1.80354 & 3.80078 & 3.68862 & $\mathrm{H}$ & 0.57498 & -0.73573 & -0.73833 \\
\hline $\mathrm{C}$ & -3.14298 & 3.53674 & 3.47954 & $\mathrm{C}$ & 10.37577 & 6.46555 & 6.17147 \\
\hline $\mathrm{C}$ & 0.21538 & 4.06344 & 2.11727 & $\mathrm{C}$ & 10.77612 & 7.76972 & 5.81535 \\
\hline $\mathrm{C}$ & 0.77035 & 3.93934 & 0.81461 & $\mathrm{C}$ & 12.13377 & 8.08082 & 5.66116 \\
\hline $\mathrm{C}$ & 1.02700 & 3.45339 & -1.29904 & $\mathrm{C}$ & 13.10810 & 7.09218 & 5.86811 \\
\hline $\mathrm{C}$ & 2.31206 & 3.96986 & -0.83859 & $\mathrm{C}$ & 12.72210 & 5.79487 & 6.23910 \\
\hline $\mathrm{C}$ & 2.15166 & 4.27914 & 0.48194 & $\mathrm{C}$ & 11.36428 & 5.48488 & 6.39303 \\
\hline $\mathrm{C}$ & 0.82927 & 2.97878 & -2.60719 & $\mathrm{C}$ & 8.91481 & 6.13106 & 6.33378 \\
\hline $\mathrm{C}$ & -0.34439 & 2.48812 & -3.19297 & $\mathrm{C}$ & 6.77115 & 5.31924 & 5.39739 \\
\hline
\end{tabular}




\begin{tabular}{|c|c|c|c|c|c|c|c|}
\hline $\mathrm{C}$ & -2.51020 & 1.86930 & -3.47816 & $\mathrm{C}$ & 8.86728 & 4.37971 & 4.52013 \\
\hline $\mathrm{C}$ & -1.80574 & 1.59263 & -4.70195 & $\mathrm{C}$ & 8.22961 & 6.68294 & 3.96310 \\
\hline $\mathrm{C}$ & -0.48954 & 1.97053 & -4.52611 & $\mathrm{H}$ & 10.01976 & 8.55153 & 5.66772 \\
\hline $\mathrm{C}$ & 1.10969 & 4.39996 & 3.26158 & $\mathrm{H}$ & 12.43206 & 9.09958 & 5.38725 \\
\hline $\mathrm{C}$ & 2.26217 & 3.62598 & 3.50714 & $\mathrm{H}$ & 14.17072 & 7.33606 & 5.75121 \\
\hline $\mathrm{C}$ & 3.09461 & 3.87858 & 4.61569 & $\mathrm{H}$ & 13.48092 & 5.02371 & 6.41662 \\
\hline $\mathrm{C}$ & 2.74269 & 4.93119 & 5.49072 & $\mathrm{H}$ & 11.06888 & 4.47222 & 6.69652 \\
\hline $\mathrm{C}$ & 1.61275 & 5.72251 & 5.24667 & $\mathrm{H}$ & 8.76461 & 5.32243 & 7.07015 \\
\hline $\mathrm{C}$ & 0.80217 & 5.46753 & 4.13417 & $\mathrm{H}$ & 8.33418 & 7.01281 & 6.65650 \\
\hline $\mathrm{C}$ & 4.29015 & 3.04199 & 4.90215 & $\mathrm{H}$ & 6.32211 & 6.21524 & 5.85765 \\
\hline $\mathrm{C}$ & 5.20437 & 2.64884 & 3.87658 & $\mathrm{H}$ & 6.25096 & 5.07009 & 4.45828 \\
\hline $\mathrm{C}$ & 6.32467 & 1.82823 & 4.20884 & $\mathrm{H}$ & 6.74798 & 4.46585 & 6.09494 \\
\hline $\mathrm{C}$ & 6.54116 & 1.47484 & 5.55835 & $\mathrm{H}$ & 8.81500 & 3.60219 & 5.30009 \\
\hline $\mathrm{C}$ & 5.66341 & 1.87996 & 6.57089 & $\mathrm{H}$ & 8.30524 & 4.06460 & 3.62115 \\
\hline $\mathrm{C}$ & 4.53965 & 2.64388 & 6.23274 & $\mathrm{H}$ & 9.91400 & 4.61463 & 4.27072 \\
\hline $\mathrm{C}$ & 7.22690 & 1.29166 & 3.15973 & $\mathrm{H}$ & 7.74424 & 7.59409 & 4.35100 \\
\hline $\mathrm{C}$ & 7.66651 & 2.10241 & 2.08006 & $\mathrm{H}$ & 7.65899 & 6.27564 & 3.10851 \\
\hline $\mathrm{C}$ & 8.58513 & 1.59451 & 1.14386 & $\mathrm{~N}$ & 8.21129 & 5.63364 & 5.05233 \\
\hline $\mathrm{C}$ & 9.06885 & 0.28660 & 1.25393 & $\mathrm{H}$ & 9.27748 & 6.88886 & 3.69389 \\
\hline $\mathrm{C}$ & 8.63927 & -0.53242 & 2.31198 & $\mathrm{C}$ & -10.96091 & -6.76384 & -0.65805 \\
\hline $\mathrm{C}$ & 7.72606 & -0.02853 & 3.24611 & $\mathrm{C}$ & -10.45367 & -7.33342 & 0.52704 \\
\hline $\mathrm{C}$ & 0.94630 & 0.36807 & 1.86590 & $\mathrm{C}$ & -10.91567 & -6.90549 & 1.77823 \\
\hline $\mathrm{C}$ & 2.01333 & 0.78783 & 1.04432 & $\mathrm{C}$ & -11.89794 & -5.90652 & 1.85946 \\
\hline $\mathrm{C}$ & 3.33875 & 0.61249 & 1.45918 & $\mathrm{C}$ & -12.42593 & -5.34738 & 0.68563 \\
\hline $\mathrm{C}$ & 3.61340 & 0.00250 & 2.69203 & $\mathrm{C}$ & -11.96308 & -5.77700 & -0.56515 \\
\hline $\mathrm{C}$ & 2.56096 & -0.41830 & 3.51785 & $\mathrm{C}$ & -10.42416 & -7.19011 & -2.00216 \\
\hline $\mathrm{C}$ & 1.23416 & -0.23026 & 3.10928 & $\mathrm{C}$ & -8.08276 & -6.42880 & -1.49062 \\
\hline $\mathrm{C}$ & -0.48002 & 0.62669 & 1.46298 & $\mathrm{C}$ & -8.73049 & -6.88813 & -3.81094 \\
\hline $\mathrm{C}$ & -2.58502 & -0.15736 & 0.41770 & $\mathrm{C}$ & -9.61232 & -4.90399 & -2.66921 \\
\hline $\mathrm{C}$ & -0.94153 & -1.82985 & 1.16137 & $\mathrm{H}$ & -9.68999 & -8.11972 & 0.47113 \\
\hline $\mathrm{C}$ & -0.47767 & -0.42244 & -0.81097 & $\mathrm{H}$ & -10.51153 & -7.35723 & 2.69183 \\
\hline $\mathrm{H}$ & 1.80844 & 1.28768 & 0.09100 & $\mathrm{H}$ & -12.26168 & -5.57227 & 2.83849 \\
\hline $\mathrm{H}$ & 4.15923 & 0.98443 & 0.84088 & $\mathrm{H}$ & -13.20609 & -4.57922 & 0.74340 \\
\hline $\mathrm{H}$ & 4.65241 & -0.12058 & 3.01284 & $\mathrm{H}$ & -12.38779 & -5.34218 & -1.47888 \\
\hline $\mathrm{H}$ & 2.77448 & -0.87565 & 4.49126 & $\mathrm{H}$ & -10.06414 & -8.23339 & -1.98175 \\
\hline $\mathrm{H}$ & 0.41165 & -0.53471 & 3.76993 & $\mathrm{H}$ & -11.18578 & -7.09306 & -2.79582 \\
\hline $\mathrm{H}$ & -1.14016 & 0.68643 & 2.34495 & $\mathrm{H}$ & -7.86591 & -6.27149 & -4.11618 \\
\hline $\mathrm{H}$ & -0.56497 & 1.55769 & 0.87711 & $\mathrm{H}$ & -8.42468 & -7.93854 & -3.67365 \\
\hline $\mathrm{H}$ & -2.70971 & 0.85141 & -0.01426 & $\mathrm{H}$ & -9.55177 & -6.81861 & -4.54396 \\
\hline $\mathrm{H}$ & -3.03927 & -0.91087 & -0.24854 & $\mathrm{H}$ & -10.46583 & -4.86398 & -3.36707 \\
\hline $\mathrm{H}$ & -3.04984 & -0.20187 & 1.41594 & $\mathrm{H}$ & -8.73559 & -4.36684 & -3.07612 \\
\hline $\mathrm{H}$ & -1.36121 & -1.81951 & 2.18051 & $\mathrm{~N}$ & -9.22055 & -6.35241 & -2.48388 \\
\hline $\mathrm{H}$ & -1.48145 & -2.55357 & 0.53236 & $\mathrm{H}$ & -9.88801 & -4.48893 & -1.68814 \\
\hline
\end{tabular}




\begin{tabular}{llllllll}
$\mathrm{H}$ & 0.12876 & -2.08478 & 1.18456 & $\mathrm{H}$ & -7.21888 & -5.91357 & -1.94360 \\
$\mathrm{H}$ & -0.54913 & 0.60648 & -1.19265 & $\mathrm{H}$ & -8.39081 & -5.93631 & -0.55584 \\
$\mathrm{H}$ & -1.03383 & -1.11100 & -1.46422 & $\mathrm{H}$ & -7.84983 & -7.49285 & -1.31493 \\
$\mathrm{H}$ & -8.68264 & -0.52606 & -0.08936 & & & & \\
\hline
\end{tabular}




\section{General Procedure for Exchange Spectroscopy (EXSY) Experiments}

The EXSY (2D NOESY) measurements ${ }^{\mathrm{S} 25}$ were conducted at $30{ }^{\circ} \mathrm{C}$ at various mixing times $\left(\tau_{\mathrm{m}}\right)$. The exchange rate constants, $k_{\mathrm{e}}$, were determined by the following equations:

$$
\begin{aligned}
& \underset{k_{\mathrm{BA}}}{\stackrel{k_{\mathrm{AB}}}{\longrightarrow}} \mathrm{B} \\
& k_{\mathrm{ex}}=k_{\mathrm{AB}}+k_{\mathrm{BA}} \\
& \quad=\left(1 / \tau_{\mathrm{m}}\right) \ln [(r+1) /(r-1)]
\end{aligned}
$$

where $r$ is defined as the following equation,

$$
r=4 \mathrm{X}_{\mathrm{A}} \mathrm{X}_{\mathrm{B}}\left(I_{\mathrm{AA}}+I_{\mathrm{BB}}\right) /\left(I_{\mathrm{AB}}+I_{\mathrm{BA}}\right)-\left(\mathrm{X}_{\mathrm{A}}-\mathrm{X}_{\mathrm{B}}\right)^{2}
$$

where $\mathrm{X}_{\mathrm{A}}$ and $\mathrm{X}_{\mathrm{B}}$ are the mole fractions of $\mathrm{A}$ and $\mathrm{B}$, respectively, $I_{\mathrm{AB}}$ and $I_{\mathrm{BA}}$ are the peak volumes of the cross peaks between the signals $\mathrm{A}$ and $\mathrm{B}$, respectively, and $I_{\mathrm{AA}}$ and $I_{\mathrm{BB}}$ are the peak volumes of the diagonal signals.

The $\boldsymbol{k}_{\mathrm{ox}}$ values of $\mathbf{1}_{\mathrm{Na} 2}$ in the presence of 0.5 equiv of $\mathbf{G X}$ (a $1: 1$ mixture of $\mathbf{1}_{\mathrm{Na} 2}$ and $\mathbf{1}_{\mathrm{Na} 2} \supset \mathbf{G X}$ ) were estimated from the slope of the linear plots of $\ln [(r+1) /(r-1)]$ as a function of $\tau_{\mathrm{m}}$ (Figures S31-S33). 

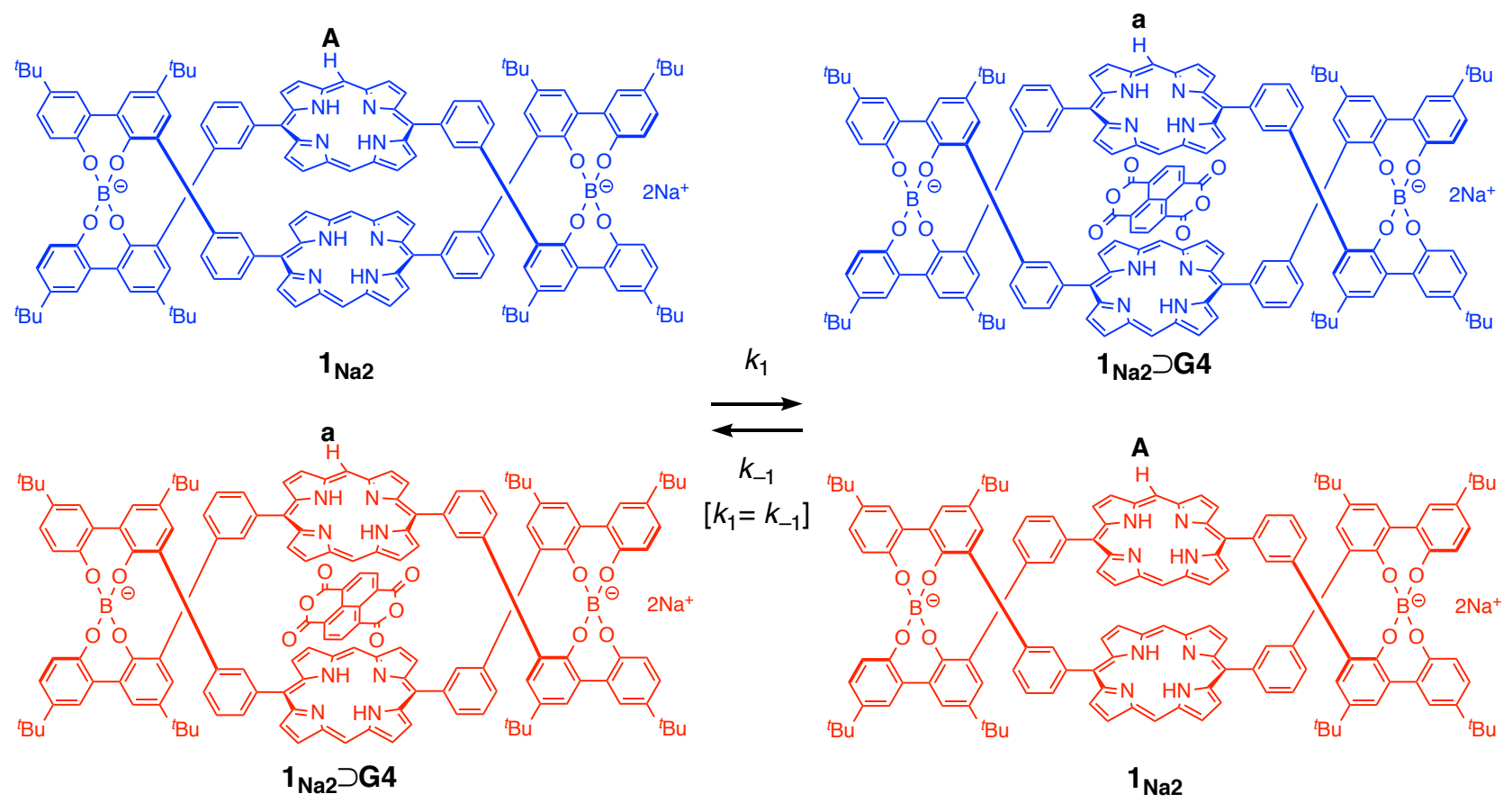

(a)

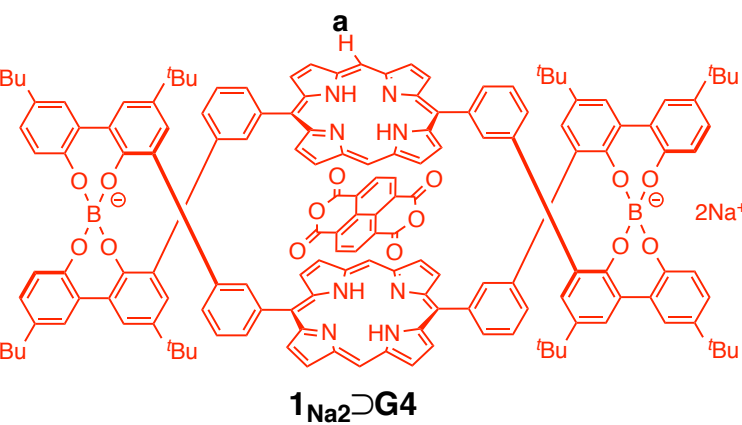

(b)
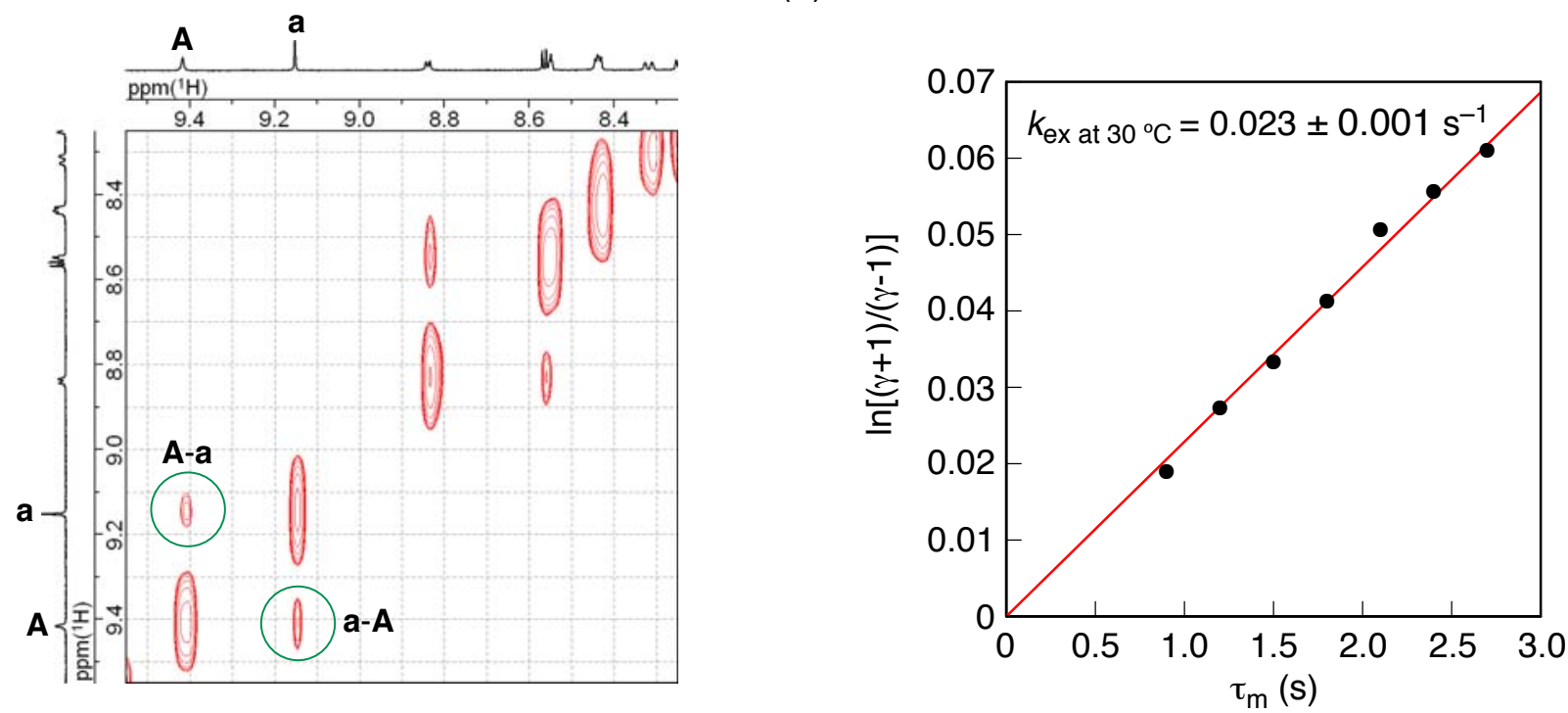

Figure S31. Determination of the apparent exchange rate constant, $k_{\mathrm{ex}}\left(k_{\mathrm{ex}}=k_{1}+k_{-1}\right)$, for interconversion between free $\mathbf{1}_{\mathrm{Na} 2}$ and complexed $\mathbf{1}_{\mathrm{Na} 2} \supset \mathbf{G 4}$. (a) Partial 2D EXSY (NOESY) spectrum $\left(500 \mathrm{MHz}, \mathrm{CD}_{3} \mathrm{CN}, 30{ }^{\circ} \mathrm{C},\left[\mathbf{1}_{\mathrm{Na} 2}\right]=0.50 \mathrm{mM}\right.$, mixing time $\left.\left(\tau_{\mathrm{m}}\right)=2.7 \mathrm{~s}\right)$ of $\mathbf{1}_{\mathrm{Na} 2}$ in the presence of 0.5 equiv of $\mathbf{G 4}$. (b) Plots of $\ln [(r+1) /(r-1)]$ as a function of $\tau_{\mathrm{m}}$ in the presence of 0.5 equiv of $\mathbf{G 4}$ in $\mathrm{CD}_{3} \mathrm{CN}$ at $30{ }^{\circ} \mathrm{C}$. 

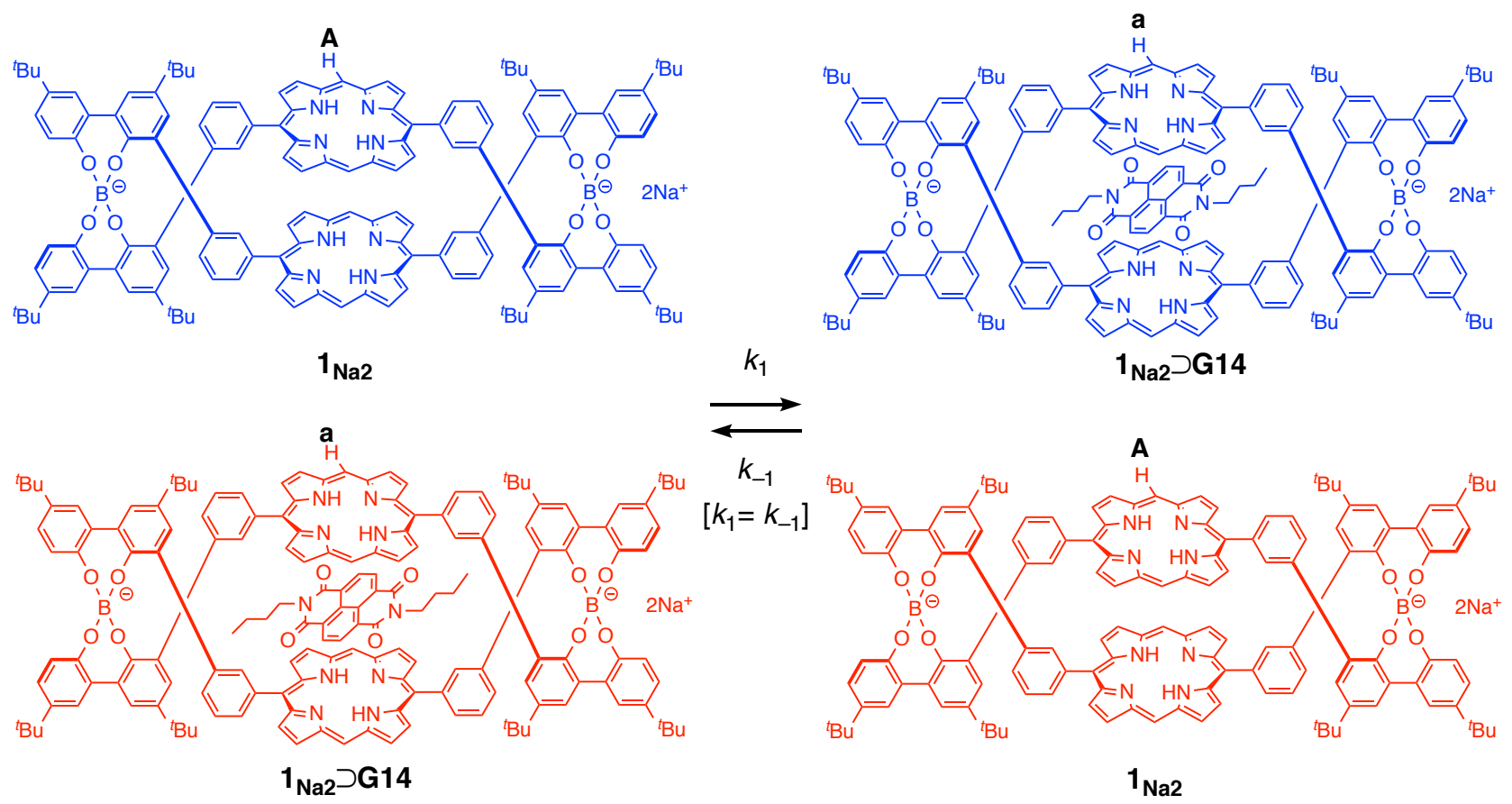

(a)

(b)
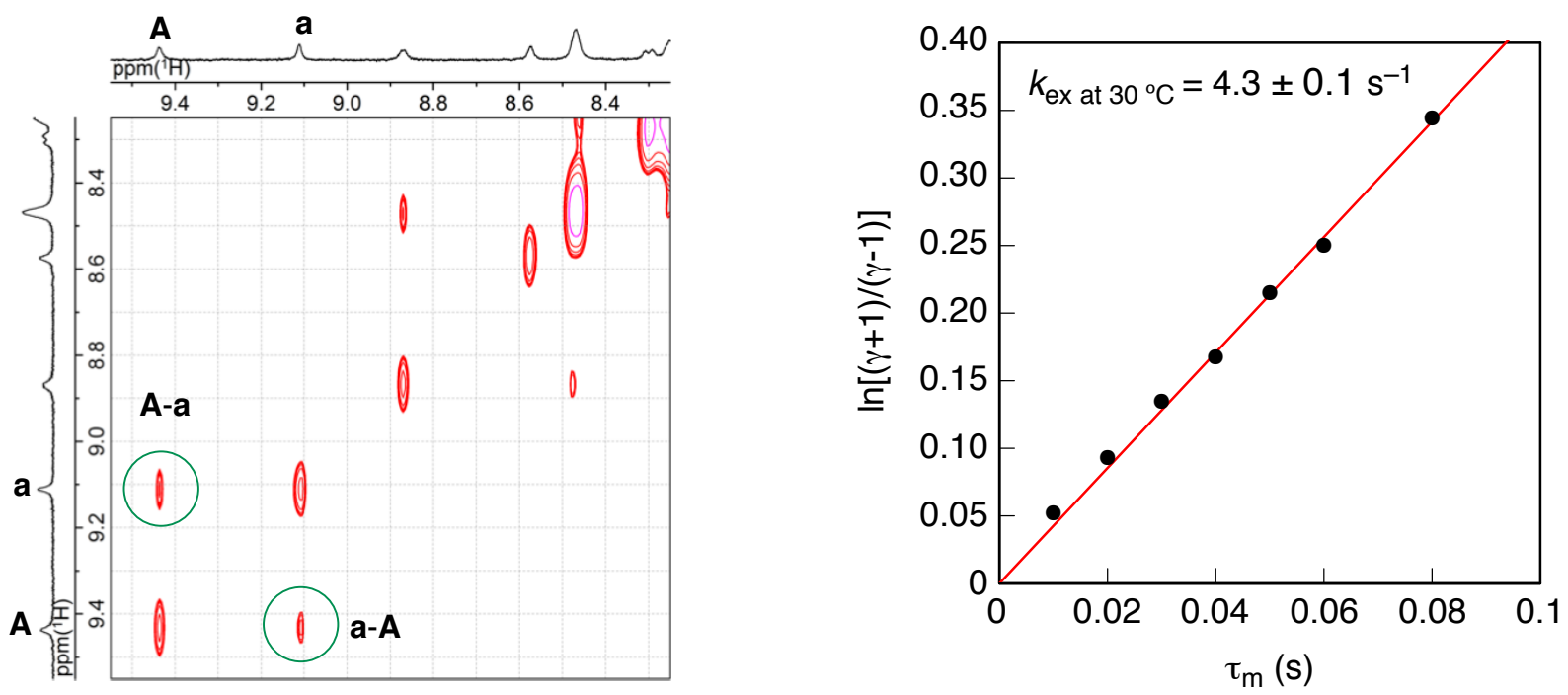

Figure S32. Determination of the apparent exchange rate constant, $k_{\mathrm{ex}}\left(k_{\mathrm{ex}}=k_{1}+k_{-1}\right)$, for interconversion between free $\mathbf{1}_{\mathbf{N a} 2}$ and complexed $\mathbf{1}_{\mathrm{Na} 2} \supset \mathbf{G 1 4}$. (a) Partial 2D EXSY (NOESY) spectrum $\left(500 \mathrm{MHz}, \mathrm{CD}_{3} \mathrm{CN}, 30^{\circ} \mathrm{C},\left[\mathbf{1}_{\mathrm{Na} 2}\right]=0.50 \mathrm{mM}\right.$, mixing time $\left.\left(\tau_{\mathrm{m}}\right)=0.08 \mathrm{~s}\right)$ of $\mathbf{1}_{\mathrm{Na} 2}$ in the presence of 0.5 equiv of G14. (b) Plots of $\ln [(r+1) /(r-1)]$ as a function of $\tau_{\mathrm{m}}$ in the presence of 0.5 equiv of $\mathbf{G 1 4}$ in $\mathrm{CD}_{3} \mathrm{CN}$ at $30^{\circ} \mathrm{C}$. 

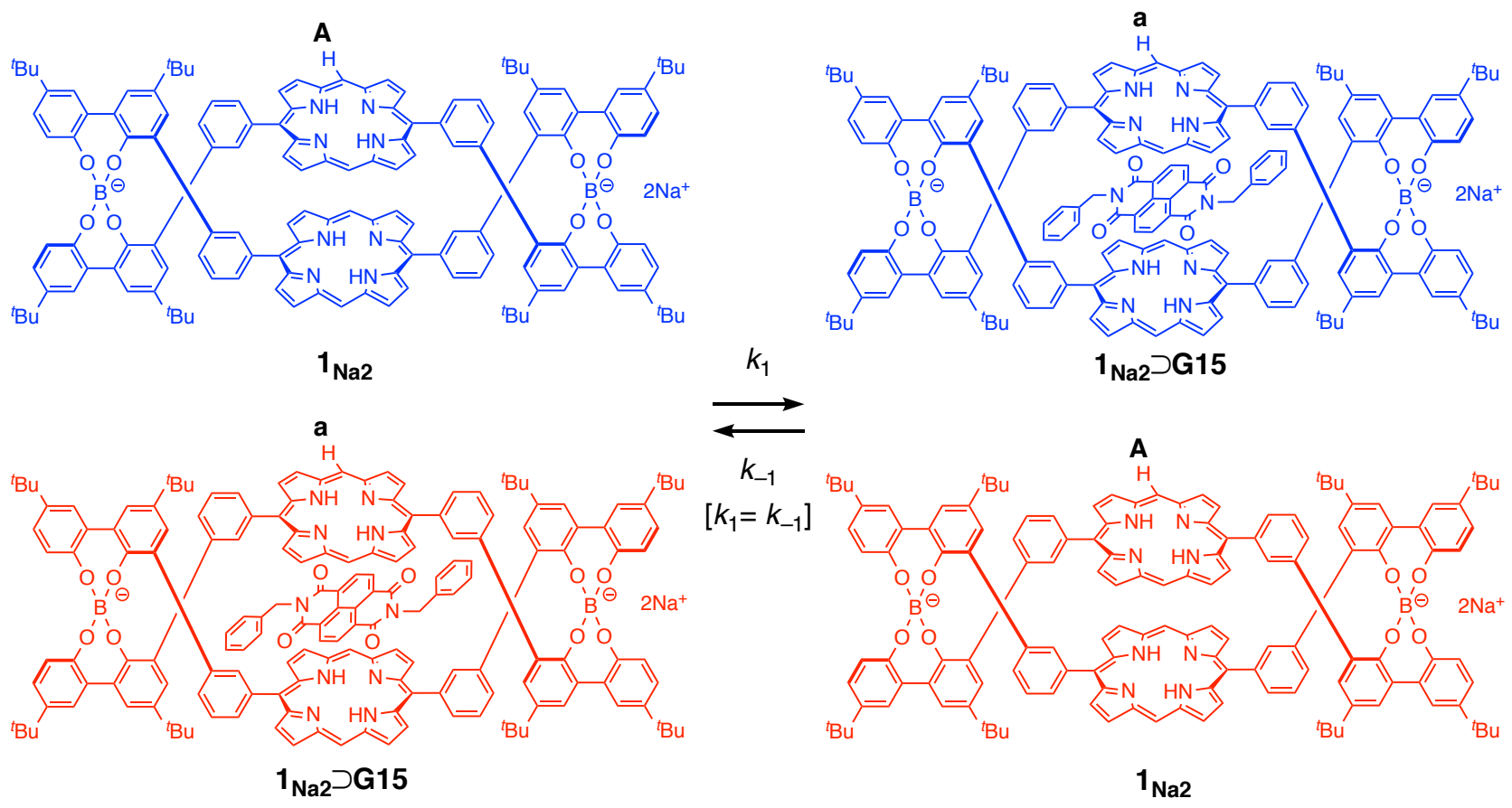

(a)

(b)
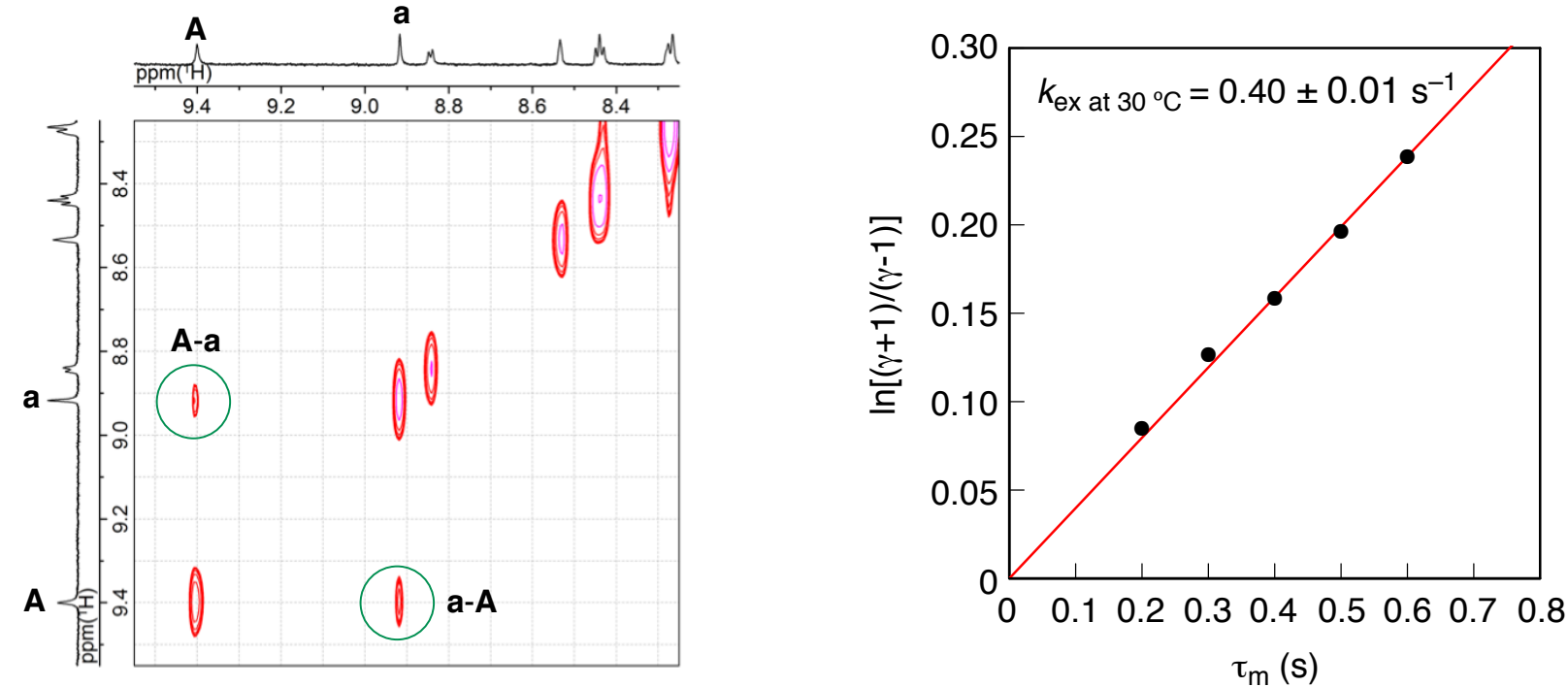

Figure S33. Determination of the apparent exchange rate constant, $k_{\mathrm{ex}}\left(k_{\mathrm{ex}}=k_{1}+k_{-1}\right)$, for interconversion between free $\mathbf{1}_{\mathbf{N a} 2}$ and complexed $\mathbf{1}_{\mathrm{Na} 2} \supset \mathbf{G 1 5}$. (a) Partial 2D EXSY (NOESY) spectrum $\left(500 \mathrm{MHz}, \mathrm{CD}_{3} \mathrm{CN}, 30{ }^{\circ} \mathrm{C},\left[\mathbf{1}_{\mathrm{Na} 2}\right]=0.50 \mathrm{mM}\right.$, mixing time $\left.\left(\tau_{\mathrm{m}}\right)=0.6 \mathrm{~s}\right)$ of $\mathbf{1}_{\mathrm{Na} 2}$ in the presence of 0.5 equiv of G15. (b) Plots of $\ln [(r+1) /(r-1)]$ as a function of $\tau_{\mathrm{m}}$ in the presence of 0.5 equiv of $\mathbf{G 1 5}$ in $\mathrm{CD}_{3} \mathrm{CN}$ at $30^{\circ} \mathrm{C}$. 


\section{CD and Absorption Spectra of $\mathbf{1}_{\mathrm{Na} 2}$ upon Inclusion Complex Formation with Various}

\section{Guests}

(a)

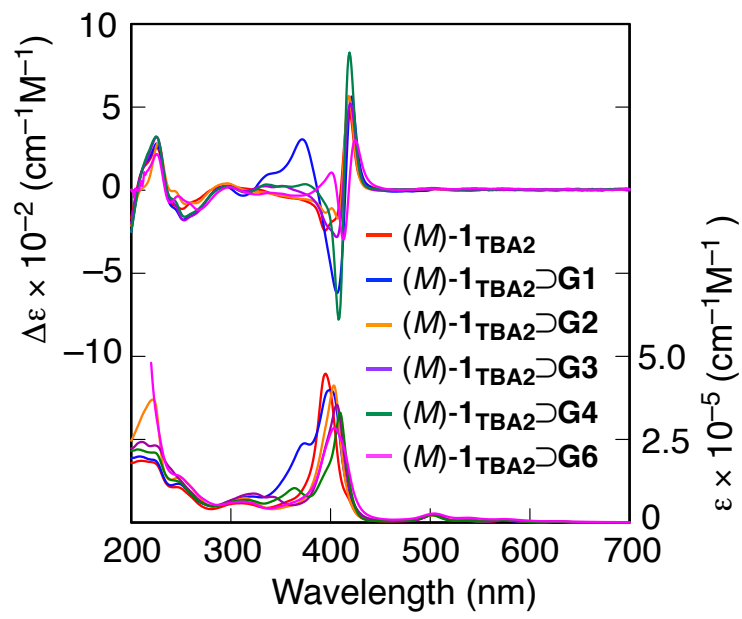

(b)

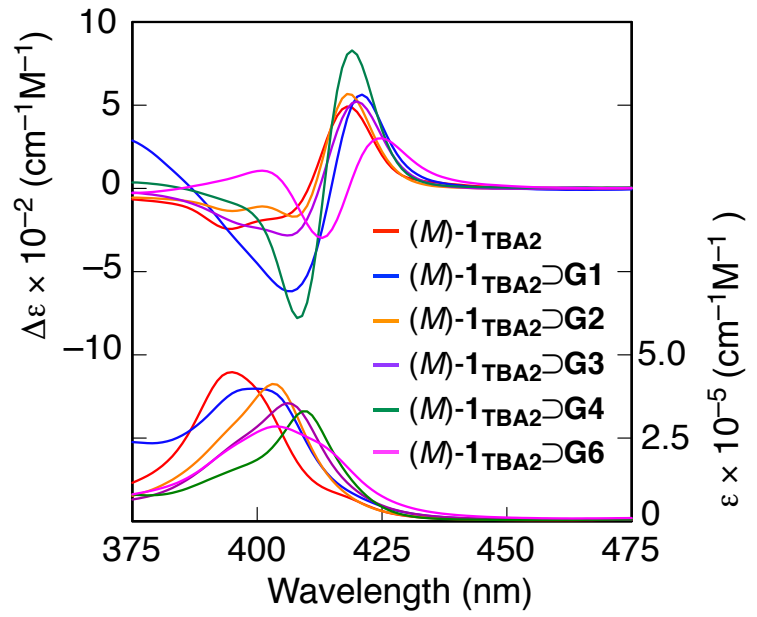

Figure S34. (a) CD and absorption spectra of $(M) \mathbf{1}_{\mathbf{T B A 2}}$ in the absence and presence of G1, G2, G3, G4, and G6 in $\mathrm{CH}_{3} \mathrm{CN}$ at ambient temperature. $\left[(M)-\mathbf{1}_{\mathbf{T B A 2}}\right]=2-200 \mu \mathrm{M},[\mathbf{G X}]=2-600 \mu \mathrm{M}$. Under the conditions, $(M)-\mathbf{1}_{\text {TBA2 }}$ almost quantitatively forms the 1:1 inclusion complex with $\mathbf{G X}$ (>96\%) based on their $K_{\mathrm{a}}$ values. The expanded CD spectra $(375-475 \mathrm{~nm})$ are also shown in $\mathrm{b}$.

(a)

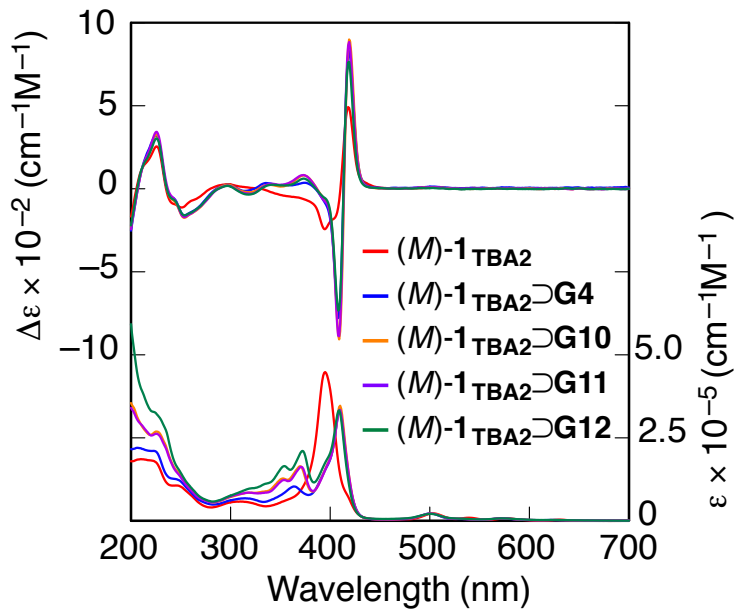

(b)

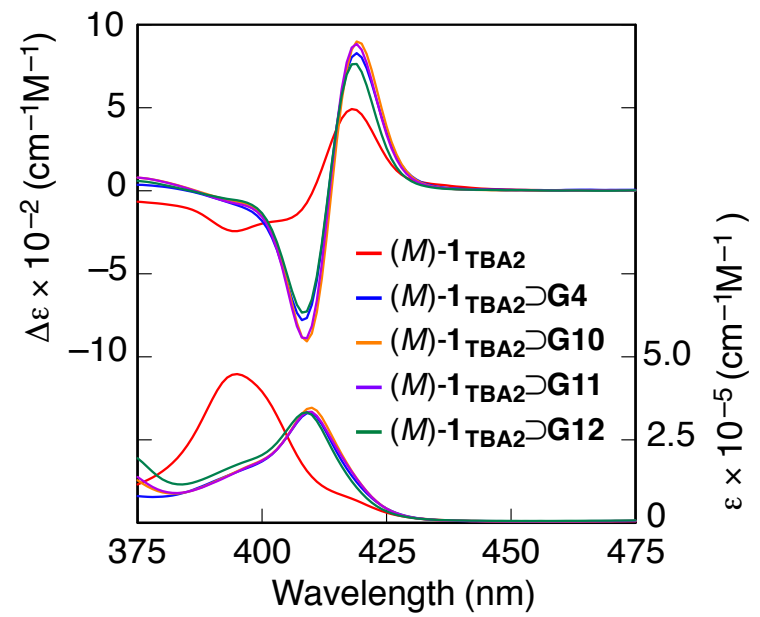

Figure S35. (a) CD and absorption spectra of $(M)-\mathbf{1}_{\text {TBA2 }}$ in the absence and presence of G4, G10, , G11, and G12 in $\mathrm{CH}_{3} \mathrm{CN}$ at ambient temperature. $\left[(M)-\mathbf{1}_{\text {TBA2 }}\right]=2-20 \mu \mathrm{M}$, [GX] = 2-60 $\mu \mathrm{M}$. Under the conditions, $(M)-\mathbf{1}_{\mathbf{T B A} 2}$ almost quantitatively forms the 1:1 inclusion complex with $\mathbf{G X}(>99 \%)$ based on their $K_{\mathrm{a}}$ values. The expanded CD spectra $(375-475 \mathrm{~nm})$ are also shown in b. 
(a)

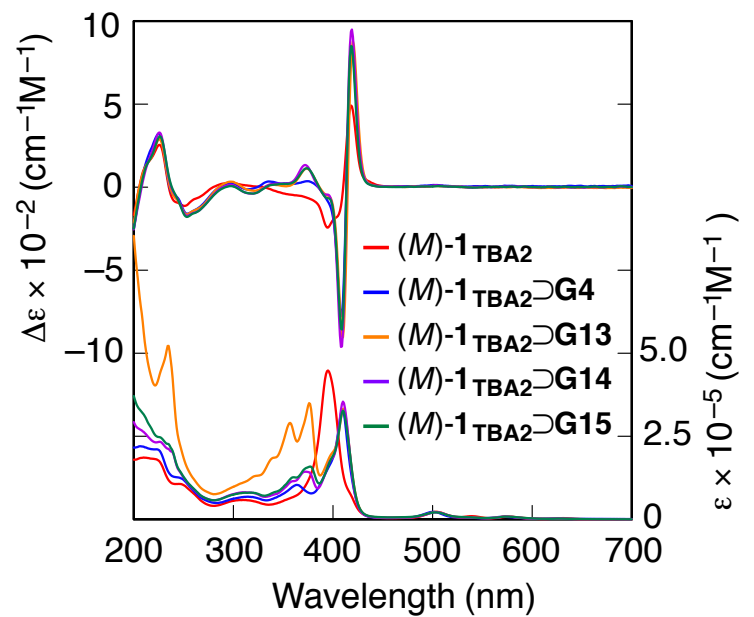

(b)

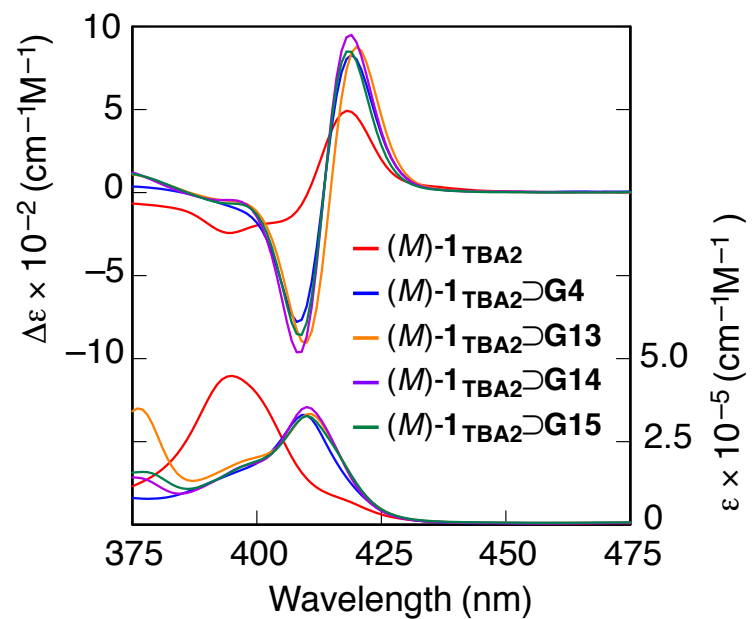

Figure S36. (a) CD and absorption spectra of $(M)-\mathbf{1}_{\mathbf{T B A 2}}\left(\left[(M)-\mathbf{1}_{\mathrm{TBA} 2}\right]=10 \mu \mathrm{M}\right)$ in the absence and presence of G4, G13, G14, and $\mathbf{G 1 5}$ in $\mathrm{CH}_{3} \mathrm{CN}$ at ambient temperature. $\left[(M)-\mathbf{1}_{\text {TBA2 }}\right]=2-100 \mu \mathrm{M}$, $[\mathbf{G X}]=2 \mu \mathrm{M}-1.0 \mathrm{mM}$. Under the conditions, $(M)-\mathbf{1}_{\text {TBA2 } 2}$ almost quantitatively forms the $1: 1$ inclusion complex with GX (>96\%) based on their $K_{\text {a }}$ values. The expanded CD spectra (375-475 $\mathrm{nm})$ are also shown in b.

Table S6. CD and Absorption Spectral Data of $(M)-\mathbf{1}_{\text {TBA2 }}$ and Its Inclusion Complexes (M)-1 $\mathbf{1}_{\mathbf{T B A} 2} \supset \mathbf{G X}$ in $\mathrm{CH}_{3} \mathrm{CN}^{a}$

\begin{tabular}{ccccc}
\hline guest & $\begin{array}{c}\text { [guest }] /[(M)- \\
\left.\text { 1 }_{\text {TBA2 }}\right]\end{array}$ & $\begin{array}{c}\lambda_{\max }(\mathrm{nm}) \\
{[\varepsilon]\left(10^{5} \mathrm{~cm}^{-1} \mathrm{M}^{-1}\right)}\end{array}$ & $\begin{array}{c}1 \text { st Cotton }(\mathrm{nm}) \\
{[\Delta \varepsilon]\left(10^{2} \mathrm{~cm}^{-1} \mathrm{M}^{-1},\right.}\end{array}$ & $\begin{array}{c}\text { 2nd Cotton }(\mathrm{nm}) \\
{[\Delta \varepsilon]\left(10^{2} \mathrm{~cm}^{-1} \mathrm{M}^{-1}\right)}\end{array}$ \\
\hline none & - & $395[4.5]$ & $418[4.9]$ & $395[-2.4]$ \\
G1 & 3 & $400[4.0]$ & $421[5.6]$ & $407[-6.2]$ \\
G2 & 3 & $403[4.1]$ & $418[5.7]$ & $407[-1.7]$ \\
G3 & 3 & $406[3.5]$ & $420[5.2]$ & $406[-2.8]$ \\
G4 & 1 & $409[3.3]$ & $419[8.3]$ & $408[-7.8]$ \\
G6 & 1 & $404[2.9]$ & $425[3.0]$ & $413[-3.0]$ \\
G10 & 2 & $410[3.3]$ & $419[9.0]$ & $409[-9.1]$ \\
G11 & 2 & $410[3.3]$ & $419[8.8]$ & $409[-8.9]$ \\
G12 & 3 & $409[3.3]$ & $419[7.6]$ & $408[-7.3]$ \\
G13 & 10 & $411[3.3]$ & $420[8.8]$ & $410[-9.0]$ \\
G14 & 3 & $410[3.5]$ & $419[9.5]$ & $408[-9.6]$ \\
G15 & 3 & $410[3.3]$ & $418[8.5]$ & $409[-8.6]$ \\
\hline
\end{tabular}

${ }^{a}\left[(M)-1_{\text {TBA2 }}\right]=2-200 \mu \mathrm{M},[\mathrm{GX}]=2 \mu \mathrm{M}-1.0 \mathrm{mM} .(M)-1_{\text {TBA2 }}$ almost quantitatively forms the $1: 1$ inclusion complex with $\mathbf{G X}(>96 \%)$ based on their $K_{\mathrm{a}}$ values. 
8. 2D NMR Spectra of $1_{\mathrm{Na} 2}$ Complexed with G6 and G15

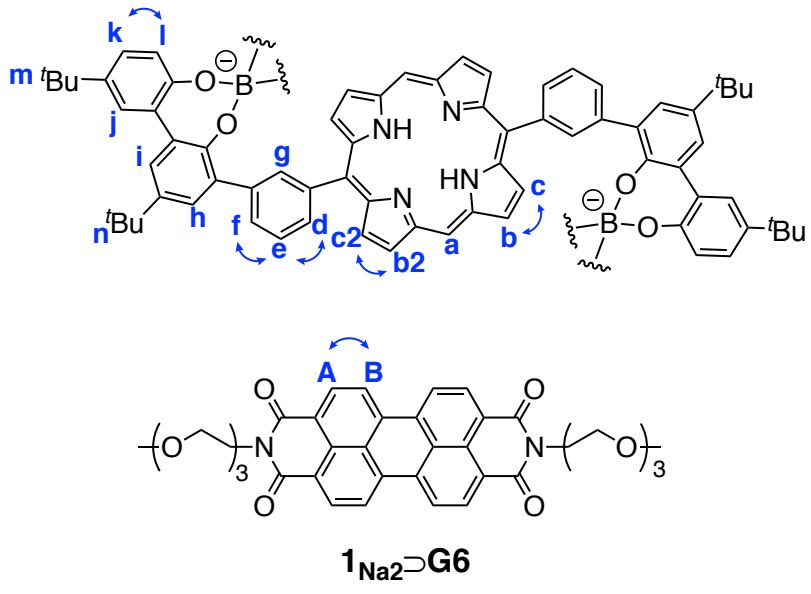

b
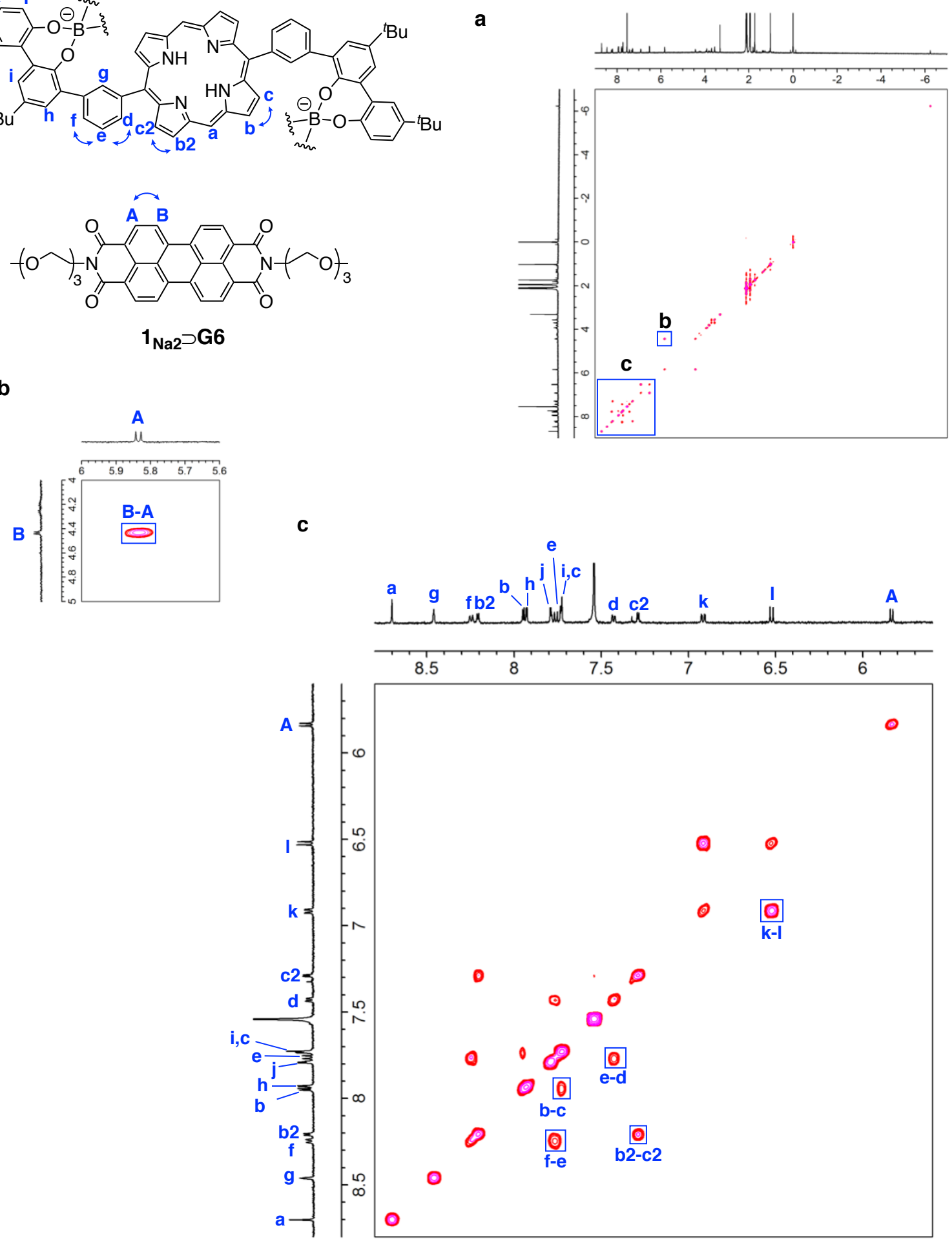

Figure S37. Full (a) and partial (b and c) gCOSY spectra $\left(500 \mathrm{MHz}, \mathrm{CD}_{3} \mathrm{CN} / \mathrm{CDCl}_{3}=5 / 2,25^{\circ} \mathrm{C}\right)$ of $\mathbf{1}_{\mathrm{Na} 2} \supset \mathbf{G 6}(0.10 \mathrm{mM})$. 


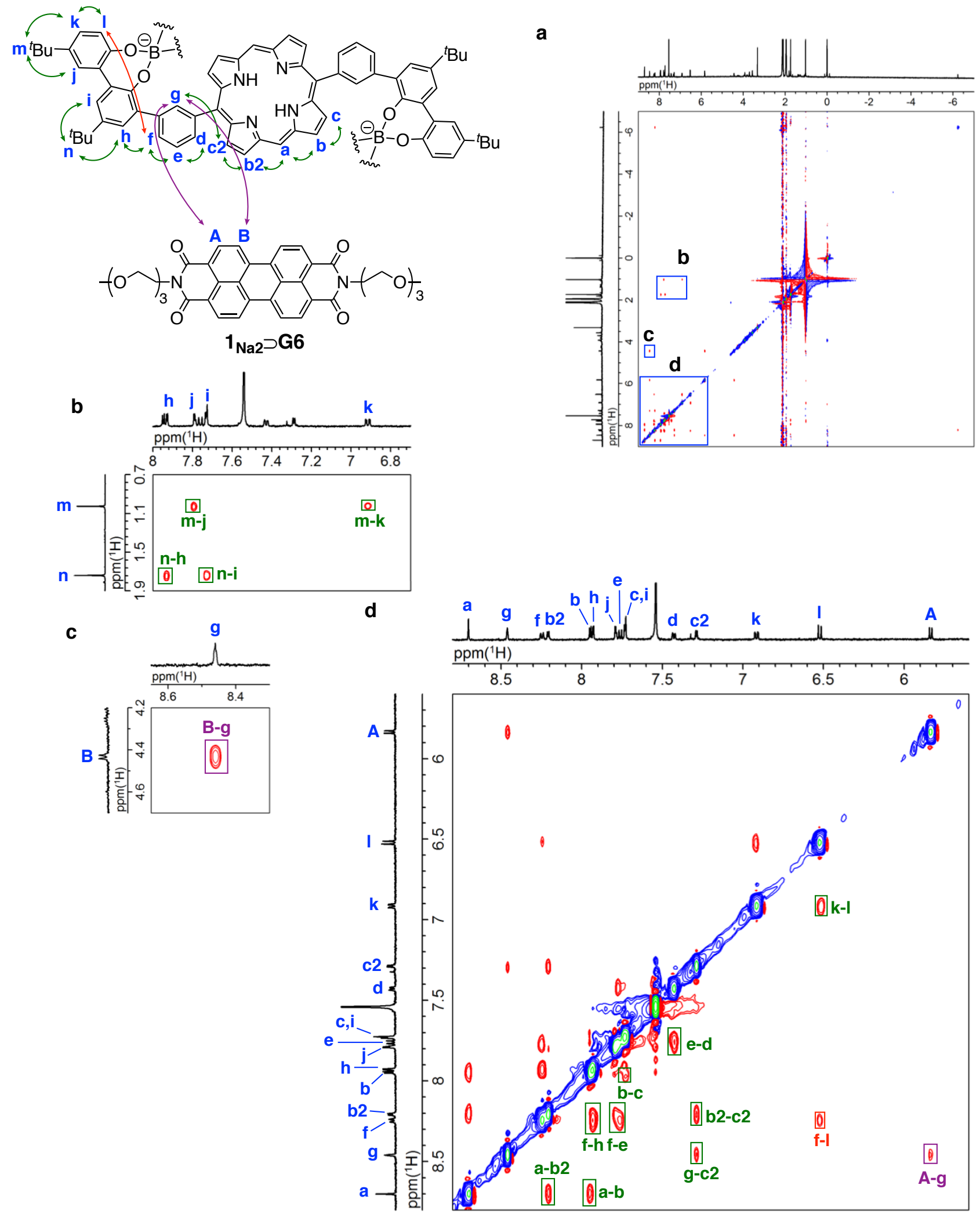

Figure S38. Full (a) and partial (b-d) ROESY spectra $\left(500 \mathrm{MHz}, \mathrm{CD}_{3} \mathrm{CN} / \mathrm{CDCl}_{3}=5 / 2,25{ }^{\circ} \mathrm{C}\right.$, mixing time $=200 \mathrm{~ms})$ of $\mathbf{1}_{\mathrm{Na} 2} \supset \mathbf{G 6}(0.10 \mathrm{mM})$. Interstrand and Intermolecular ROE cross-peaks are indicated by red and purple arrows, respectively. 

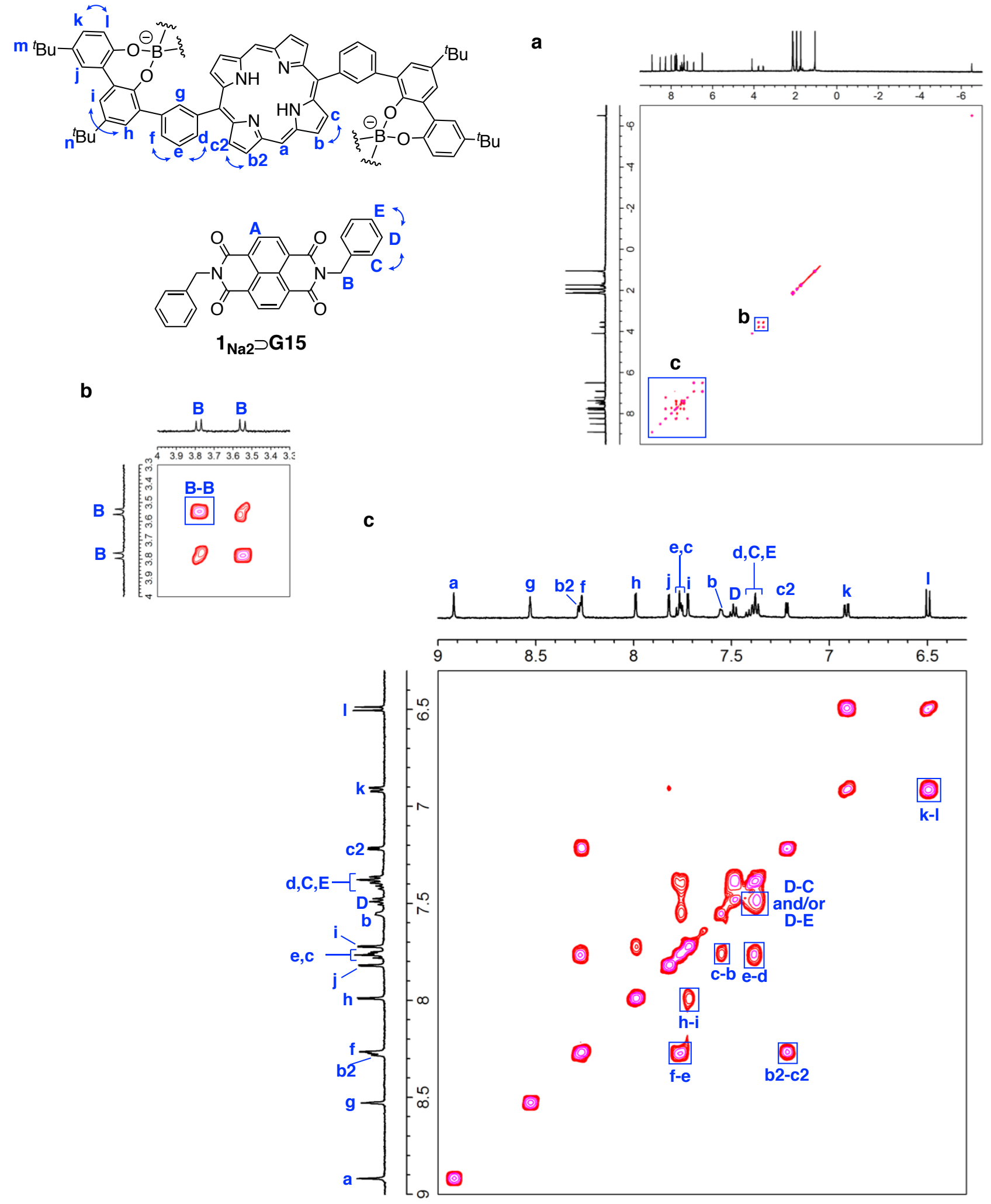

Figure S39. Full (a) and partial (b and c) gCOSY spectra (500 MHz, $\left.\mathrm{CD}_{3} \mathrm{CN}, 25^{\circ} \mathrm{C}\right)$ of $\mathbf{1}_{\mathrm{Na} 2} \supset \mathbf{G 1 5}$ $(0.50 \mathrm{mM})$. 

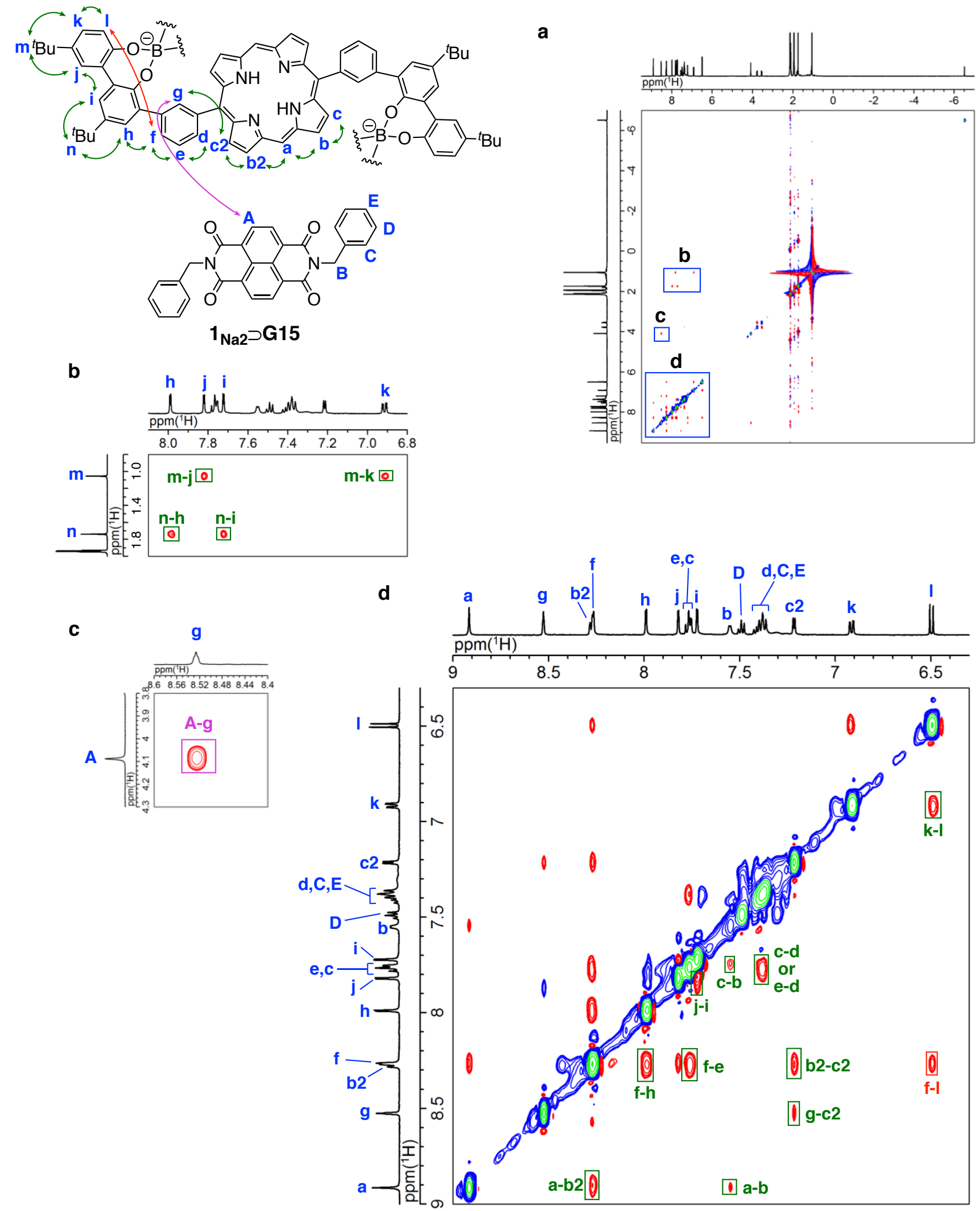

Figure S40. Full (a) and partial (b-d) ROESY spectra $\left(500 \mathrm{MHz}, \mathrm{CD}_{3} \mathrm{CN}, 25^{\circ} \mathrm{C}\right.$, mixing time $=$ $200 \mathrm{~ms})$ of $\mathbf{1}_{\mathbf{N a} 2} \supset \mathbf{G 1 5}(0.50 \mathrm{mM})$. Interstrand and Intermolecular ROE cross-peaks are indicated by red and purple arrows, respectively. 


\section{Supporting References}

(S1) Yamamoto, S.; Iida, H.; Yashima, E. Guest-Induced Unidirectional Dual Rotary and Twisting Motions of a Spiroborate-Based Double-Stranded Helicate Containing a Bisporphyrin Unit. Angew. Chem., Int. Ed, 2013, 52, 6849-6853.

(S2) CrystalClear, Version 1.36; Molecular Structure Corporation: The Woodlands, TX, 2000 and Rigaku Corporation: Tokyo, Japan.

(S3) Burla, M. C.; Caliandro, R.; Carrozzini, B.; Cascarano, G. L.; Cuocci, C.; Giacovazzo, C.; Mallamo, M.; Mazzone, A.; Polidori, G. Crystal Structure Determination and Refinement via SIR2014. J. Appl. Crystallogr. 2015, 48, 306-309.

(S4) a) Sheldrick, G. M. SHELXL-97: Program for the Refinement of Crystal Structures; University of Göttingen, Göttingen, Germany, 1997; b) Sheldrick, G. M. A Short History of SHELX. Acta Crystallogr. 2008, A64, 112-122.

(S5) a) Wakita, K. Yadokari-XG, Program for Crystal Structure Analysis; 2000; b) Kabuto, C.; Akine, S.; Nemoto, T.; Kwon, E. Release of Software (Yadokari-XG 2009) for Crystal Structure Analyses. J. Cryst. Soc. Jpn. 2009, 51, 218-224.

(S6) Torrie, G. M.; Valleau, J. P. Nonphysical Sampling Distributions in Monte Carlo FreeEnergy Estimation: Umbrella Aampling. J. Comput. Phys. 1977, 23, 187-199.

(S7) Kumar, S.; Rosenberg, J. M.; Bouzida, D.; Swendsen, R. H.; Kollman, P. A. THE Weighted Histogram Analysis Method for Free-Energy Calculations on Biomolecules. I. The Method. J. Comput. Chem. 1992, 13, 1011-1021.

(S8) Boczko, E. M.; Brooks, C. L. Constant-Temperature Free Energy Surfaces for Physical and Chemical Processes. J. Phys. Chem. 1993, 97, 4509-4513.

(S9) Roux, B. The Calculation of the Potential of Mean Force Using Computer Simulations. Comput. Phys. Commun. 1995, 91, 275-282.

(S10) Elstner, M.; Porezag, D.; Jungnickel, G.; Elsner, J.; Haugk, M.; Frauenheim, T.; Suhai, S.; Seifert, G. Self-Consistent-Charge Density-Functional Tight-Binding Method for Simulations of Complex Materials Properties. Phys. Rev. B 1998, 58, 7260-7268.

(S11) Hohenberg, P.; Kohn, W. Inhomogeneous Electron Gas. Phys. Rev. 1964, 136, B864-B871.

(S12) Kohn, W.; Sham, L. J. Self-Consistent Equations Including Exchange and Correlation Effects. Phys. Rev. 1965, 140, A1133-A1138.

(S13) Aradi, B.; Hourahine, B.; Frauenheim, T. DFTB+, a Sparse Matrix-Based Implementation of the DFTB Method. J. Phys. Chem. A 2007, 111, 5678-5684. 
(S14) Ito, S.; Irle, S.; Okamoto, Y. Implementation of Replica-Exchange Umbrella Sampling in the DFTB+ Semiempirical Quantum Chemistry Package. Comput. Phys. Commun. 2016, 204, 1-10.

(S15) Eichkorn, K.; Weigend, F.; Treutler, O.; Ahlrichs, R. Auxiliary Basis Sets for Main Row Atoms and Transition Metals and Their Use to Approximate Coulomb Potentials. Theor. Chem. Accounts Theory, Comput. Model. (Theoretica Chim. Acta) 1997, 97, 119-124.

(S16) Martyna, G. J.; Klein, M. L.; Tuckerman, M. Nosé-Hoover Chains: The Canonical Ensemble via Continuous Dynamics. J. Chem. Phys. 1992, 97, 2635-2643.

(S17) Rappe, A. K.; Casewit, C. J.; Colwell, K. S.; Goddard, W. A.; Skiff, W. M. UFF, a Full Periodic Table Force Field for Molecular Mechanics and Molecular Dynamics Simulations. J. Am. Chem. Soc. 1992, 114, 10024-10035.

(S18) Lukose, B.; Kuc, A.; Frenzel, J.; Heine, T. On the Reticular Construction Concept of Covalent Organic Frameworks. Beilstein J. Nanotechnol. 2010, 1, 60-70.

(S19) Grundkötter-Stock, B.; Bezugly, V.; Kunstmann, J.; Cuniberti, G.; Frauenheim, T.; Niehaus, T. A. SCC-DFTB Parametrization for Boron and Boranes. J. Chem. Theory Comput. 2012, 8, 1153-1163.

(S20) Tao, J.; Perdew, J. P.; Staroverov, V. N.; Scuseria, G. E. Climbing the Density Functional Ladder: Nonempirical Meta-Generalized Gradient Approximation Designed for Molecules and Solids. Phys. Rev. Lett. 2003, 91, 146401.

(S21) Eichkorn, K.; Treutler, O.; Öhm, H.; Häser, M.; Ahlrichs, R. Auxiliary Basis Sets to Approximate Coulomb Potentials. Chem. Phys. Lett. 1995, 242, 652-660.

(S22) Grimme, S.; Antony, J.; Ehrlich, S.; Krieg, H. A Consistent and Accurate ab Initio Parametrization of Density Functional Dispersion Correction (DFT-D) for the 94 Elements H-Pu. J. Chem. Phys. 2010, 132, 154104.

(S23) Grimme, S.; Ehrlich, S.; Goerigk, L. Effect of the Damping Function in Dispersion Corrected Density Functional Theory. J. Comput. Chem. 2011, 32, 1456-1465.

(S24) Furche, F.; Ahlrichs, R.; Hättig, C.; Klopper, W.; Sierka, M.; Weigend, F. Turbomole. Wiley Interdiscip. Rev. Comput. Mol. Sci. 2014, 4, 91-100.

(S25) Perrin, C. L.; Dwyer, T. J. Application of Two-Dimensional NMR to Kinetics of Chemical Exchange. Chem. Rev. 1990, 90, 935-967. 


\section{Spectroscopic Data}

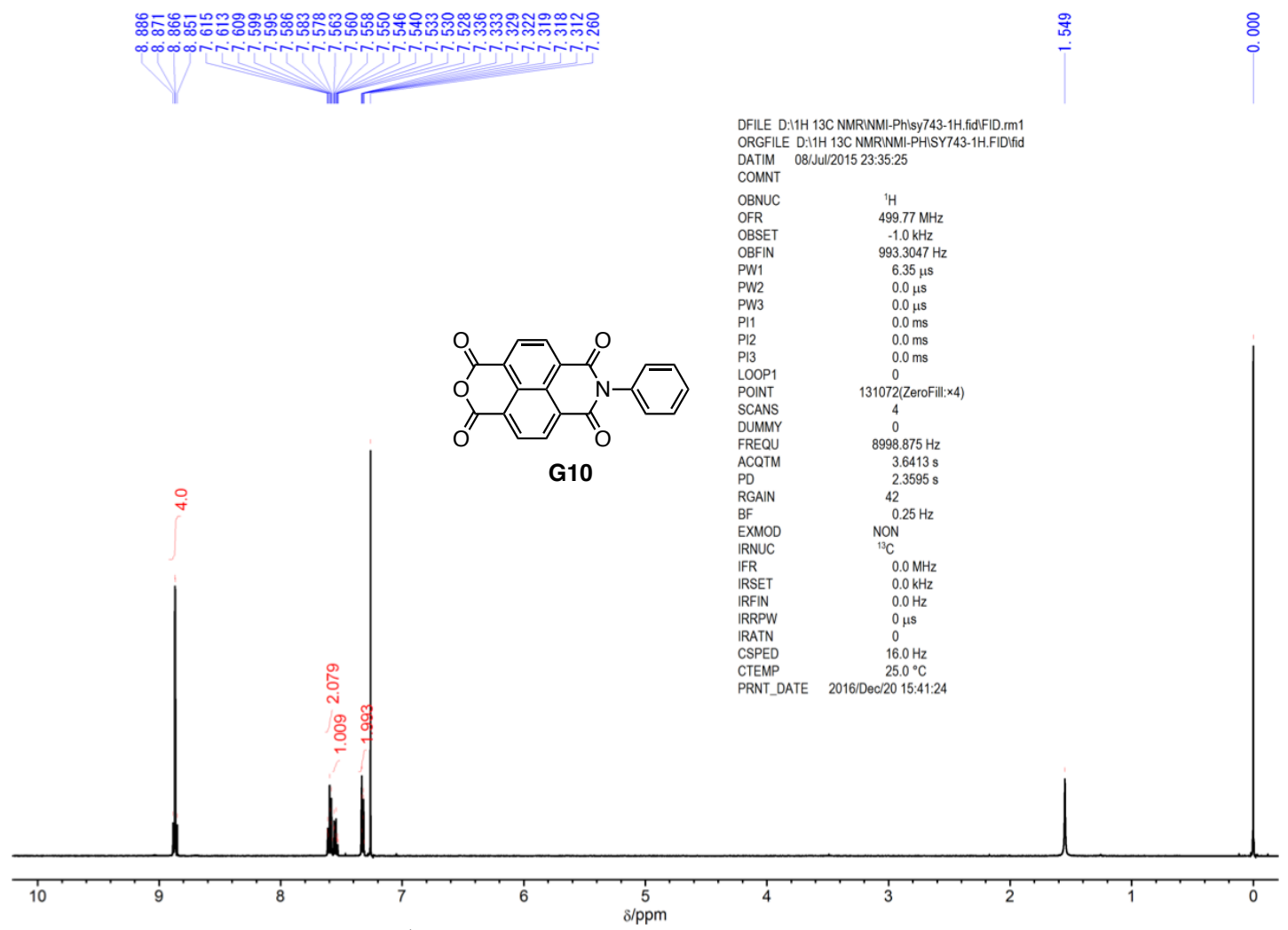

Figure S41. ${ }^{1} \mathrm{H}$ NMR spectrum of $\mathbf{G 1 0}$ in $\mathrm{CDCl}_{3}$ at $25^{\circ} \mathrm{C}$.

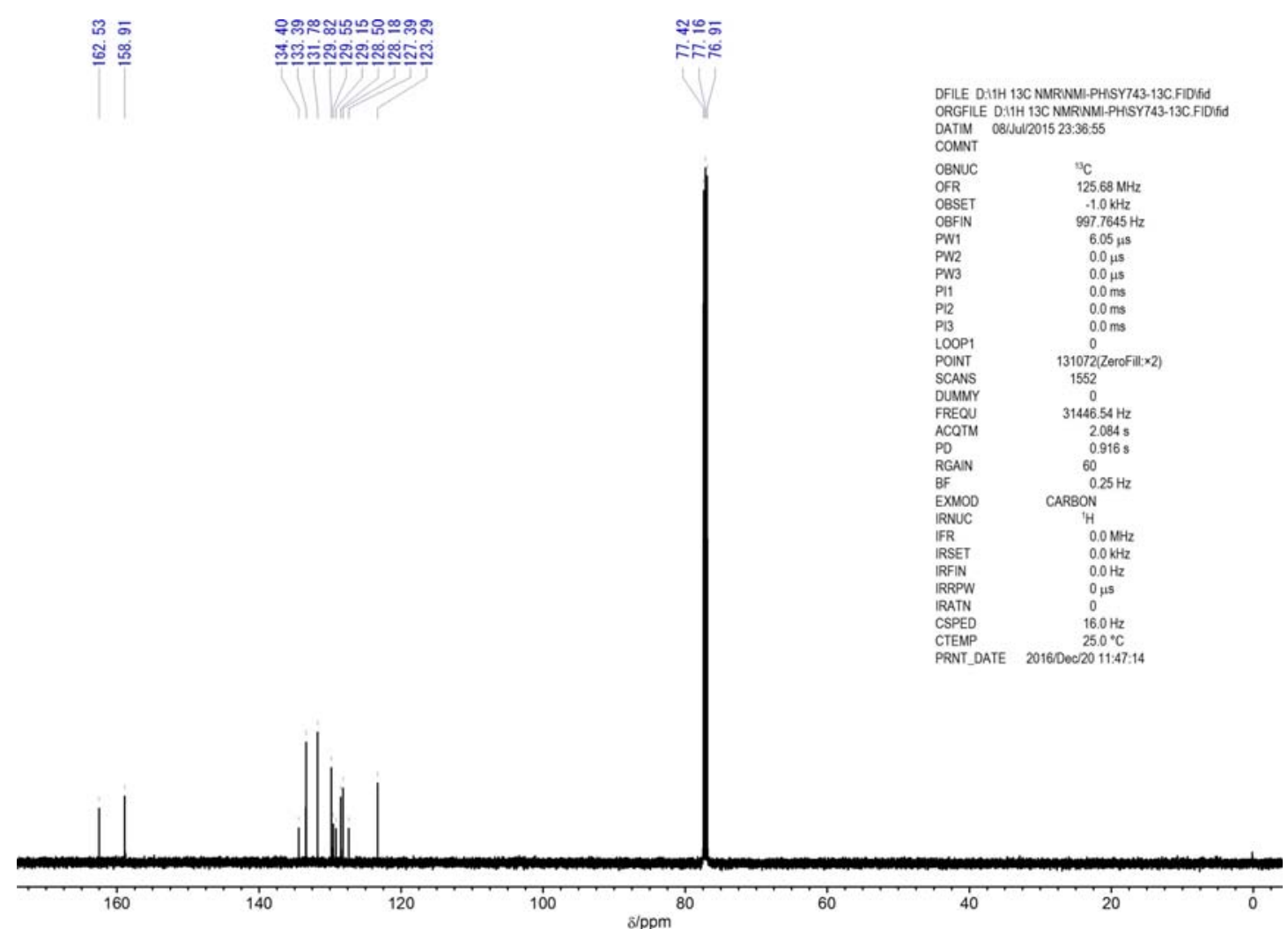

Figure S42. ${ }^{13} \mathrm{C}\left\{{ }^{1} \mathrm{H}\right\}$ NMR spectrum of $\mathbf{G 1 0}$ in $\mathrm{CDCl}_{3}$ at $25{ }^{\circ} \mathrm{C}$. 


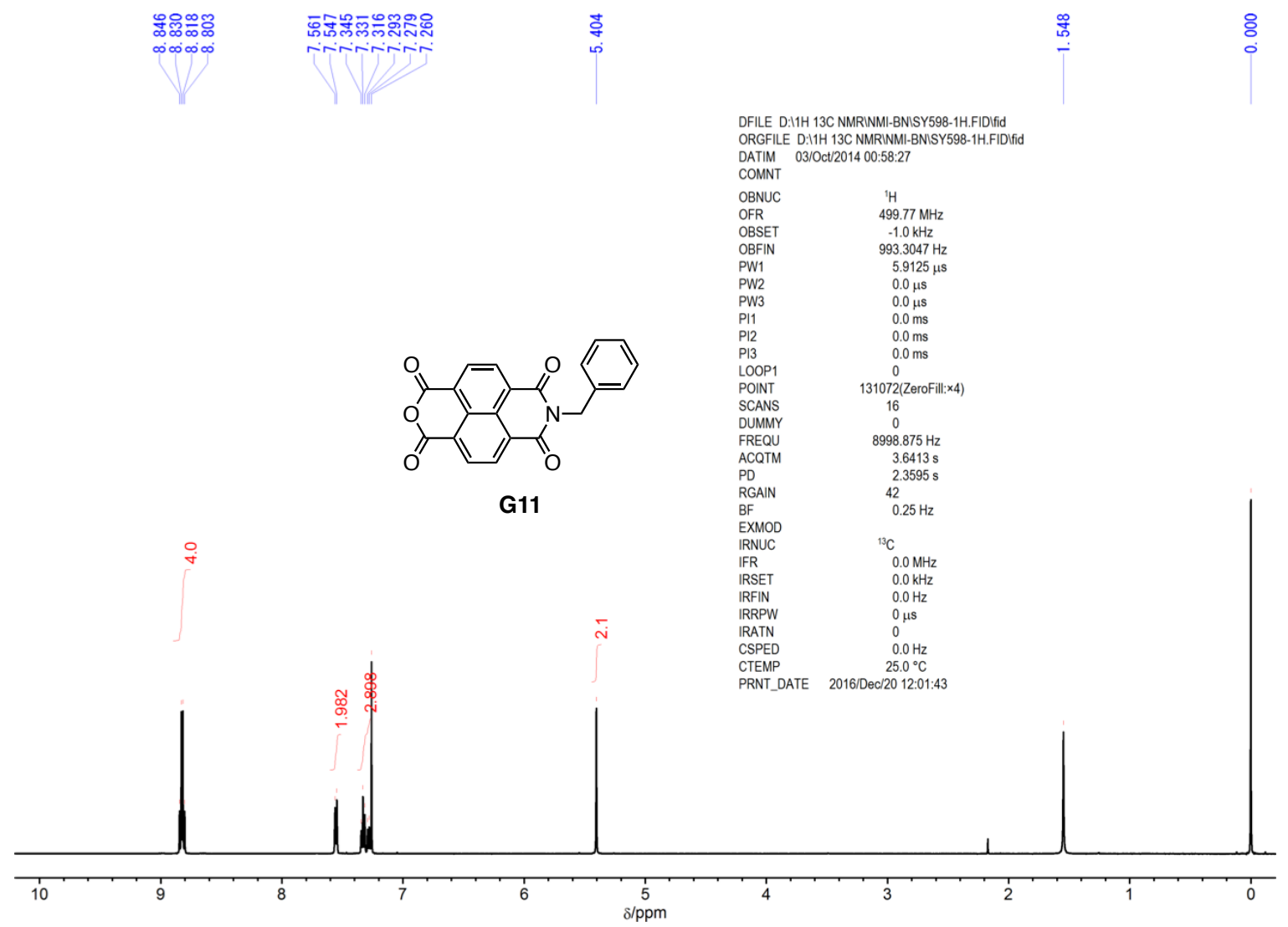

Figure S43. ${ }^{1} \mathrm{H}$ NMR spectrum of $\mathbf{G 1 1}$ in $\mathrm{CDCl}_{3}$ at $25^{\circ} \mathrm{C}$.

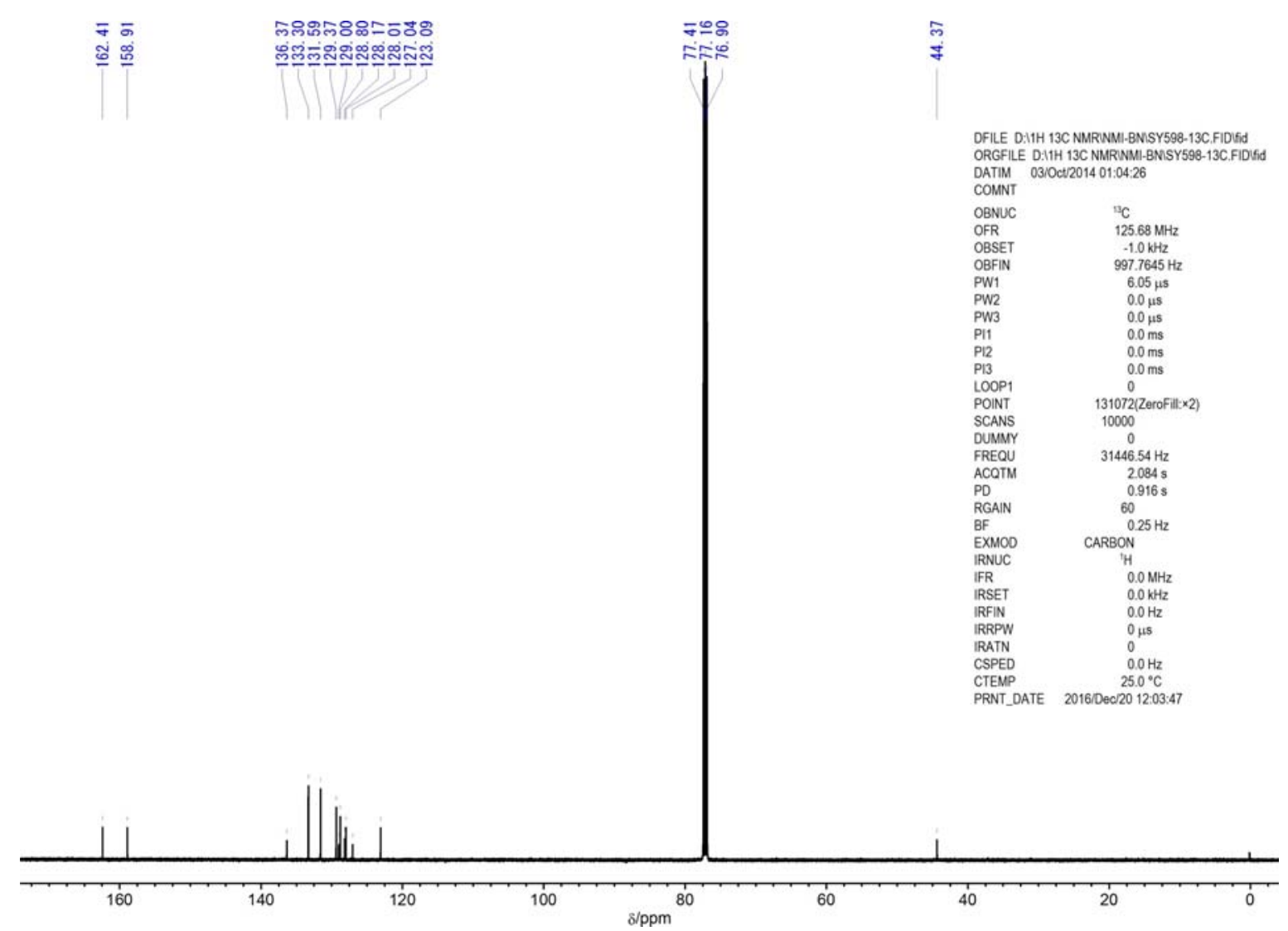

Figure S44. ${ }^{13} \mathrm{C}\left\{{ }^{1} \mathrm{H}\right\}$ NMR spectrum of $\mathbf{G 1 1}$ in $\mathrm{CDCl}_{3}$ at $25{ }^{\circ} \mathrm{C}$. 


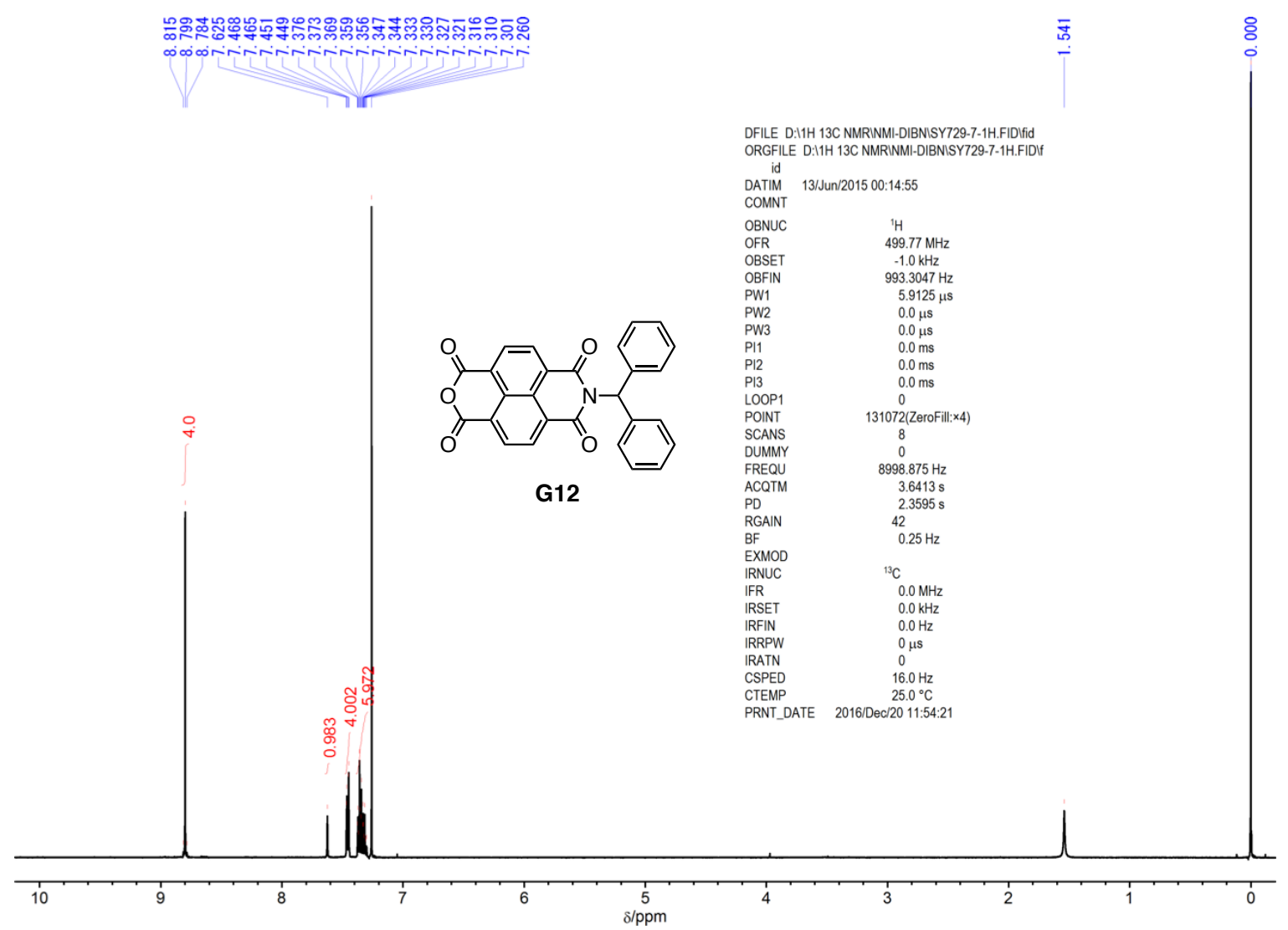

Figure S45. ${ }^{1} \mathrm{H}$ NMR spectrum of $\mathbf{G 1 2}$ in $\mathrm{CDCl}_{3}$ at $25^{\circ} \mathrm{C}$.

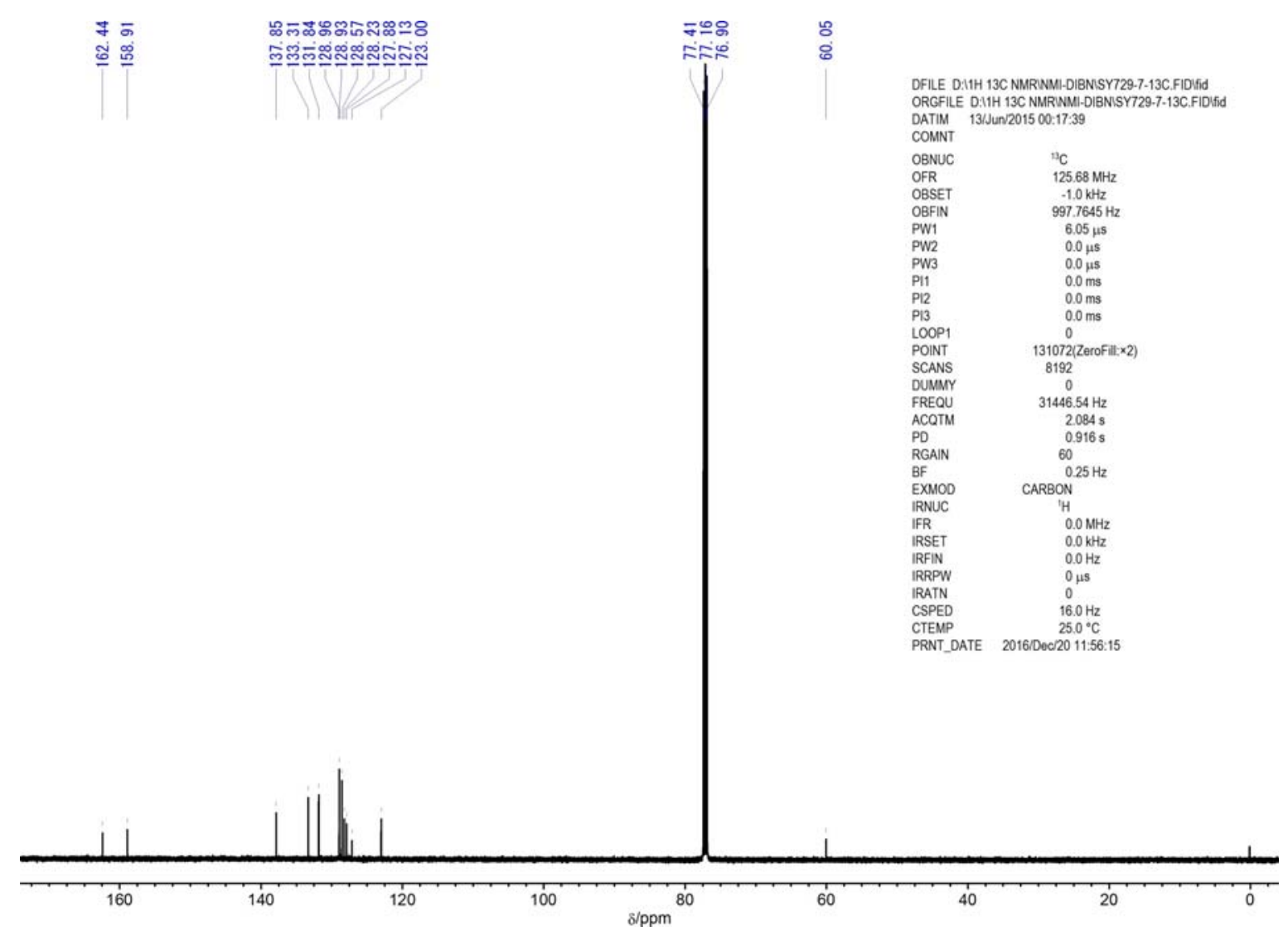

Figure S46. ${ }^{13} \mathrm{C}\left\{{ }^{1} \mathrm{H}\right\}$ NMR spectrum of $\mathbf{G 1 2}$ in $\mathrm{CDCl}_{3}$ at $25{ }^{\circ} \mathrm{C}$. 


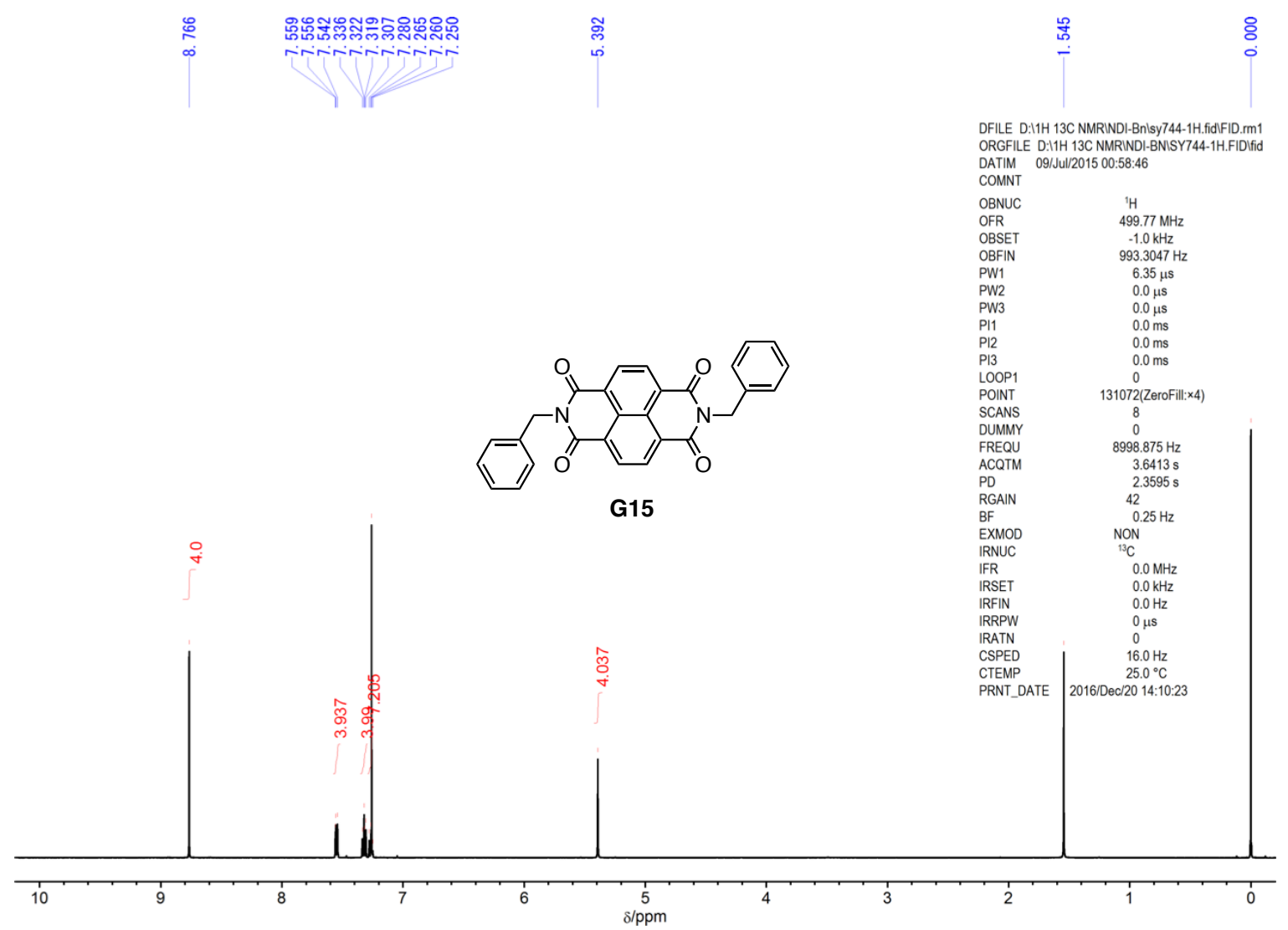

Figure S47. ${ }^{1} \mathrm{H}$ NMR spectrum of $\mathbf{G 1 5}$ in $\mathrm{CDCl}_{3}$ at $25^{\circ} \mathrm{C}$.

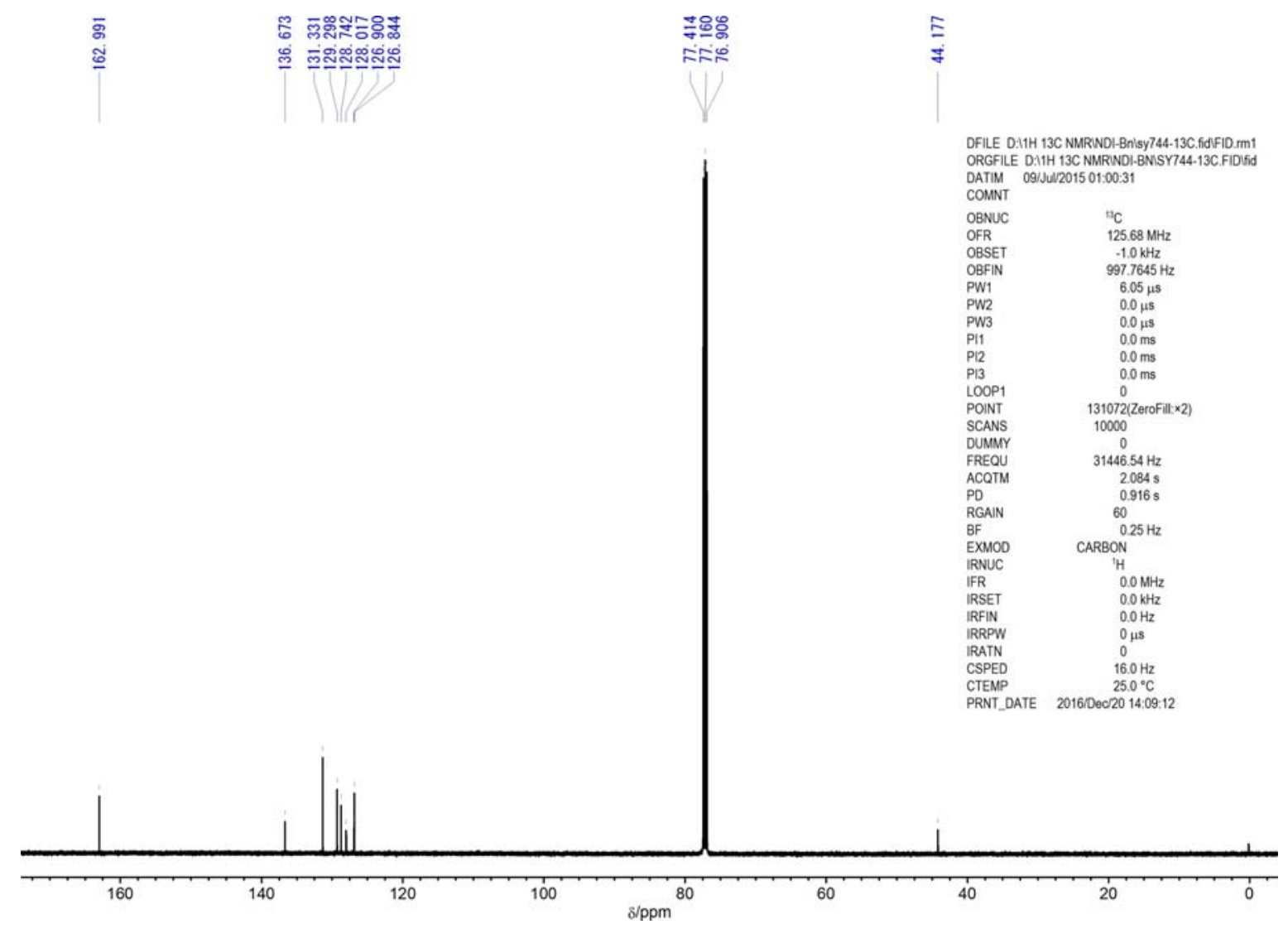

Figure S48. ${ }^{13} \mathrm{C}\left\{{ }^{1} \mathrm{H}\right\}$ NMR spectrum of $\mathbf{G 1 5}$ in $\mathrm{CDCl}_{3}$ at $25{ }^{\circ} \mathrm{C}$. 


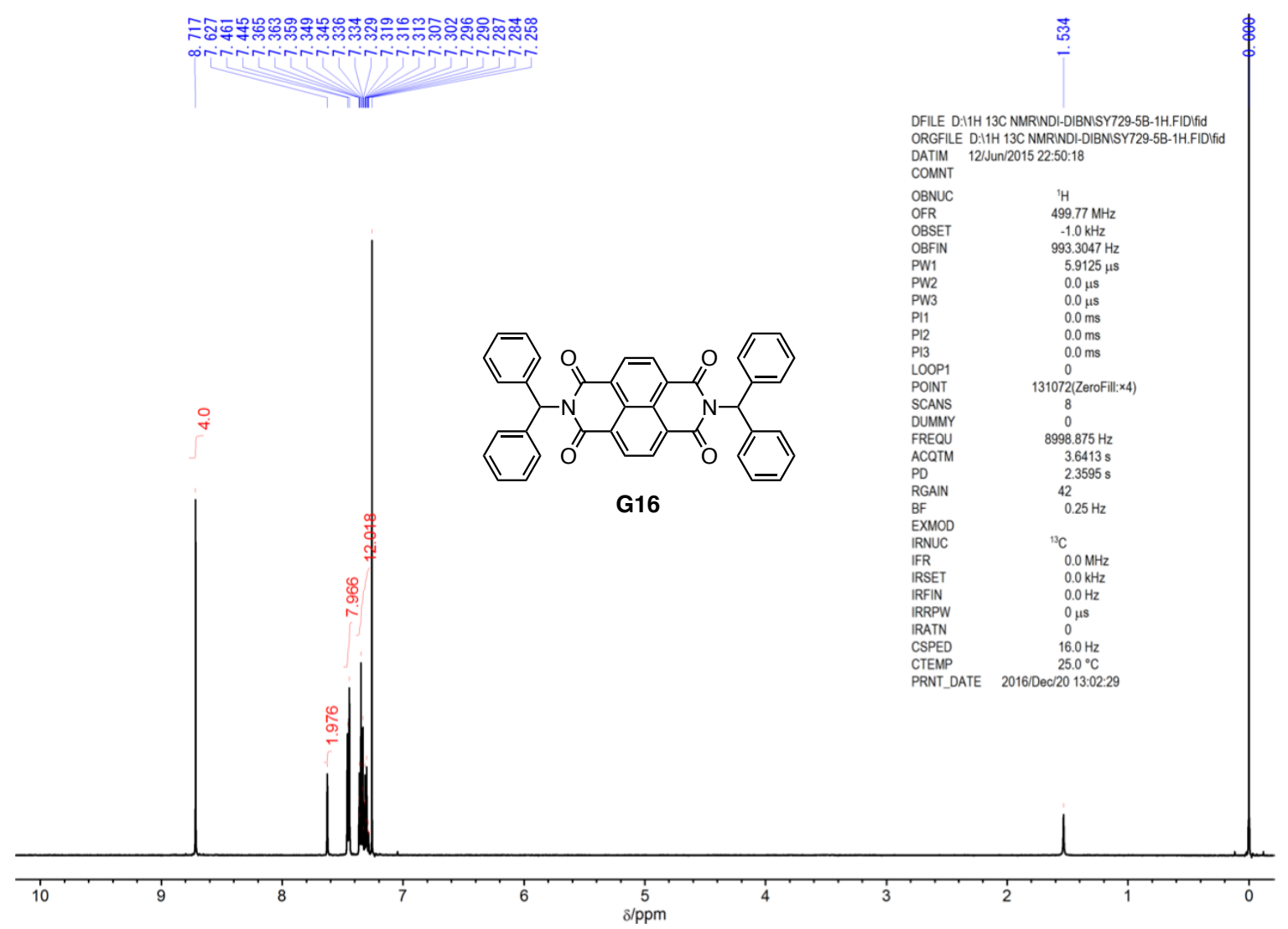

Figure S49. ${ }^{1} \mathrm{H}$ NMR spectrum of $\mathbf{G 1 6}$ in $\mathrm{CDCl}_{3}$ at $25^{\circ} \mathrm{C}$.

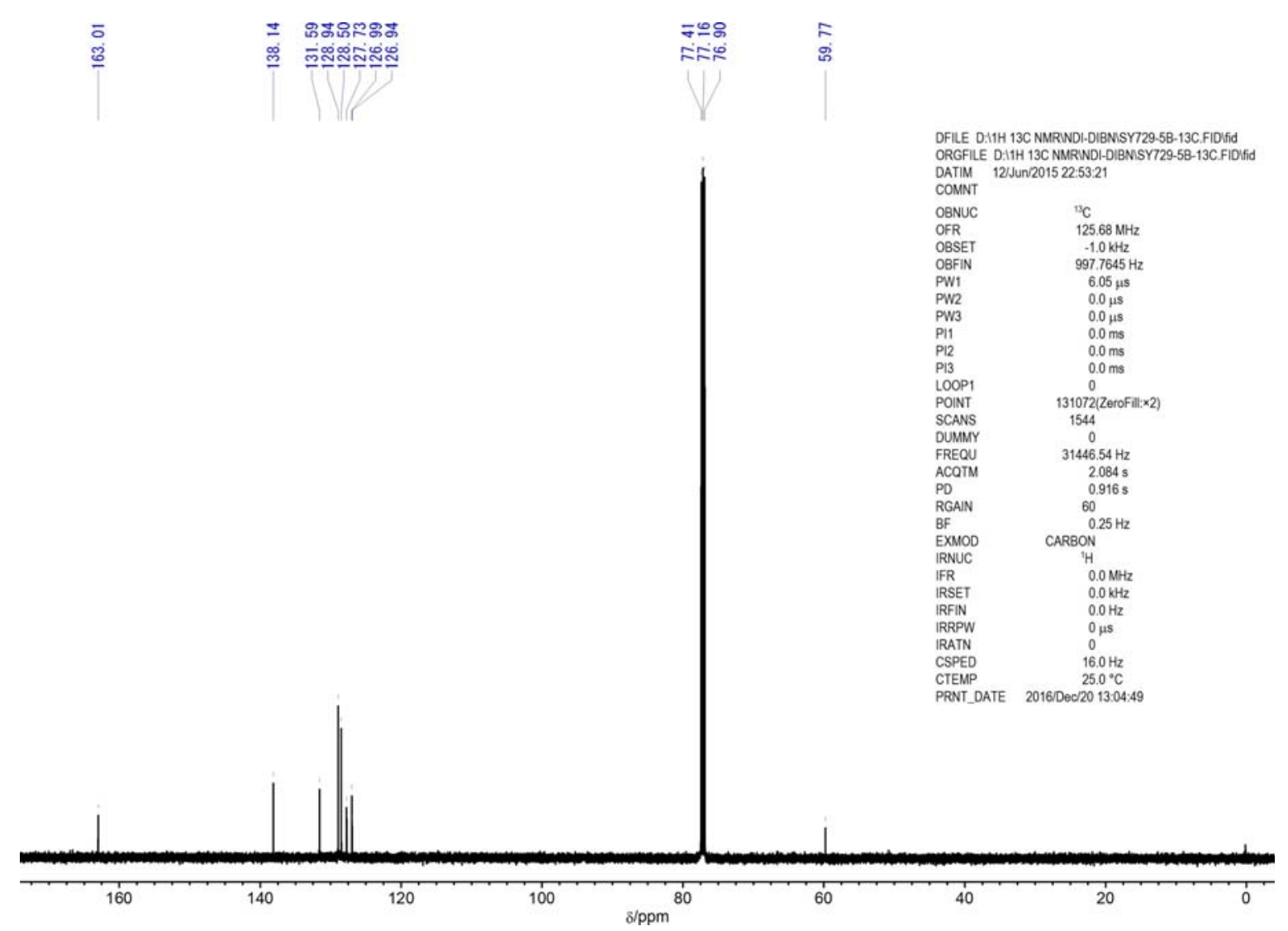

Figure S50. ${ }^{13} \mathrm{C}\left\{{ }^{1} \mathrm{H}\right\}$ NMR spectrum of $\mathbf{G 1 6}$ in $\mathrm{CDCl}_{3}$ at $25{ }^{\circ} \mathrm{C}$. 


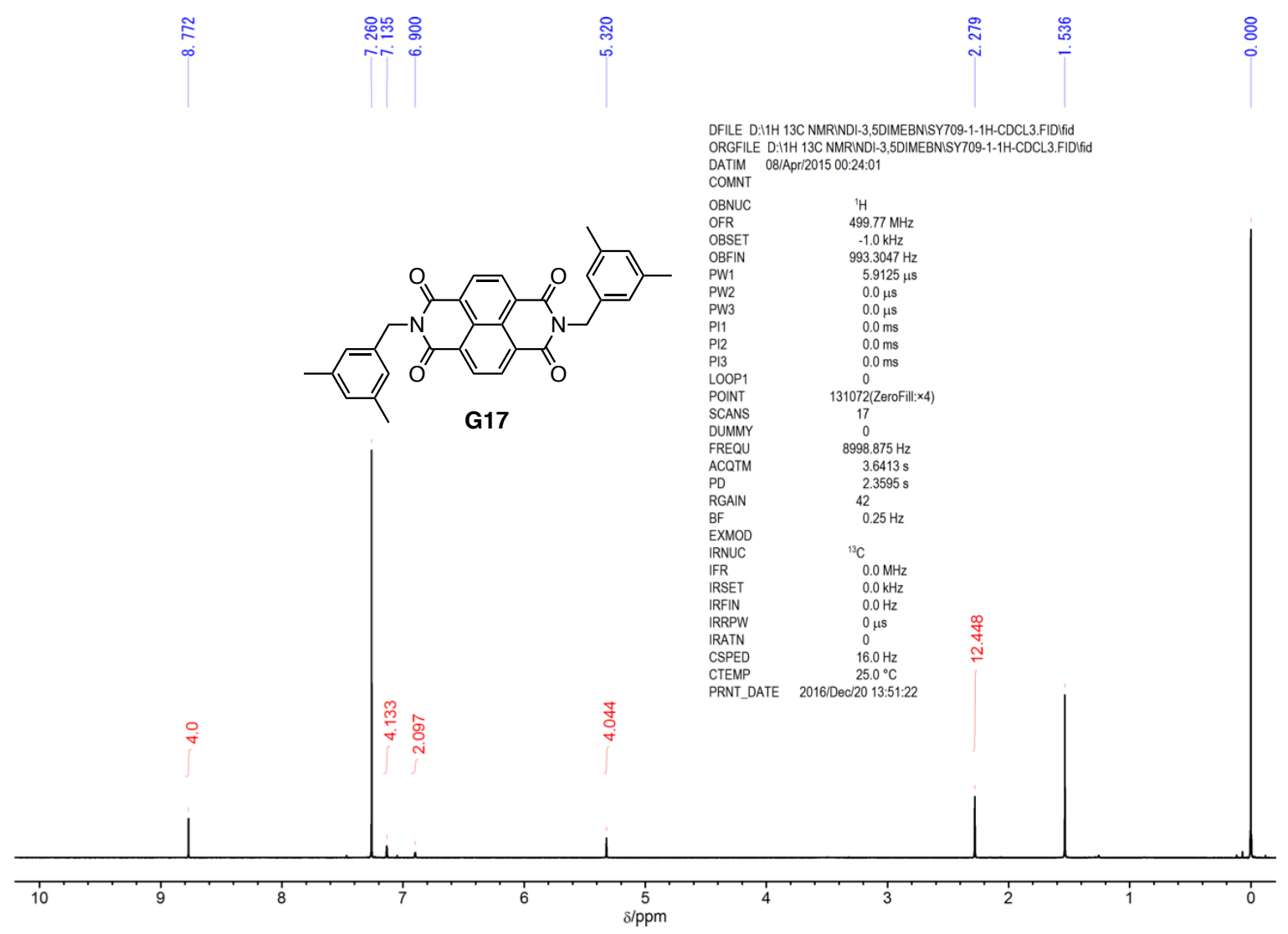

Figure S51. ${ }^{1} \mathrm{H}$ NMR spectrum of $\mathbf{G 1 7}$ in $\mathrm{CDCl}_{3}$ at $25^{\circ} \mathrm{C}$.

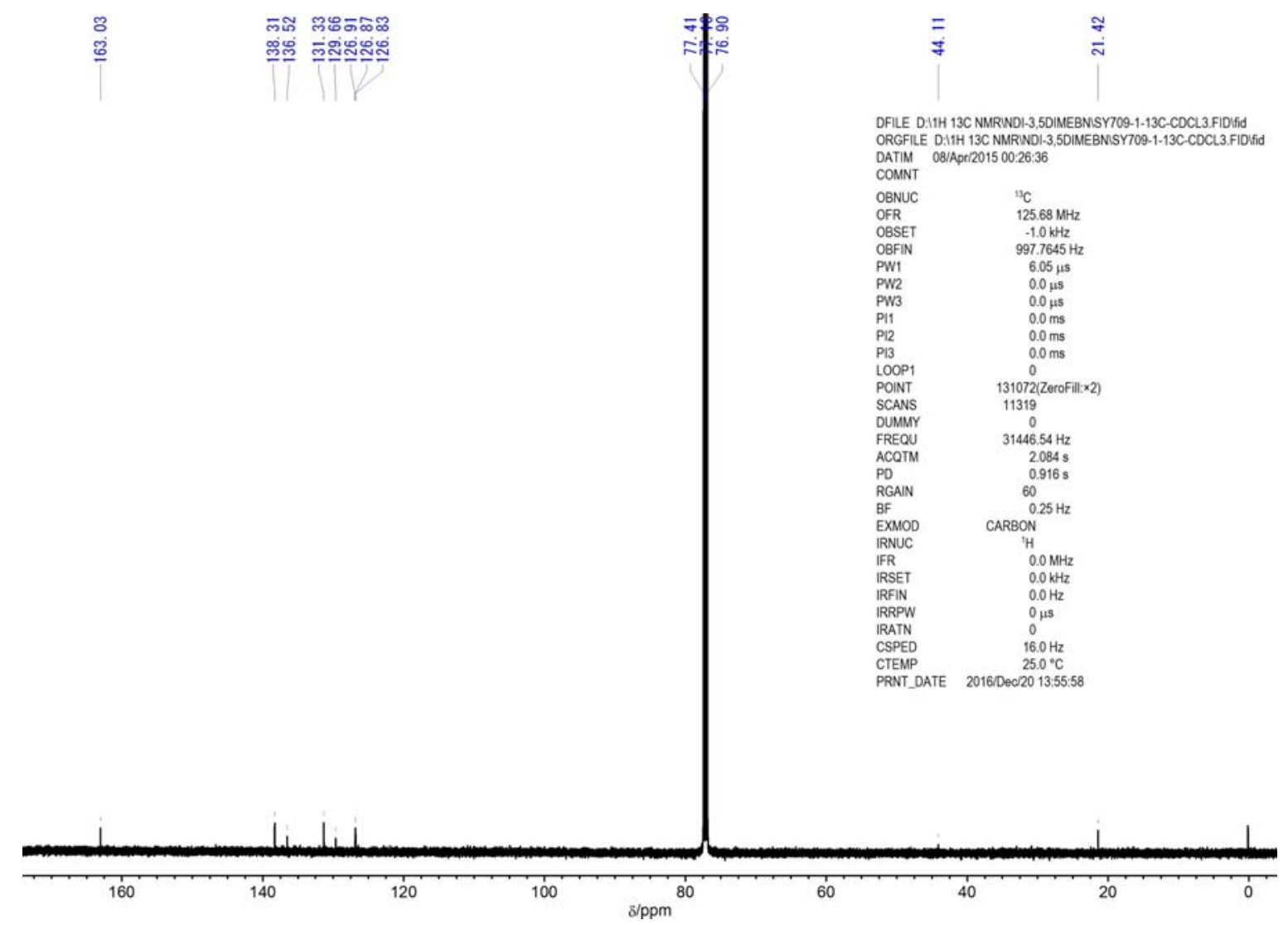

Figure S52. ${ }^{13} \mathrm{C}\left\{{ }^{1} \mathrm{H}\right\}$ NMR spectrum of $\mathbf{G 1 7}$ in $\mathrm{CDCl}_{3}$ at $25{ }^{\circ} \mathrm{C}$. 


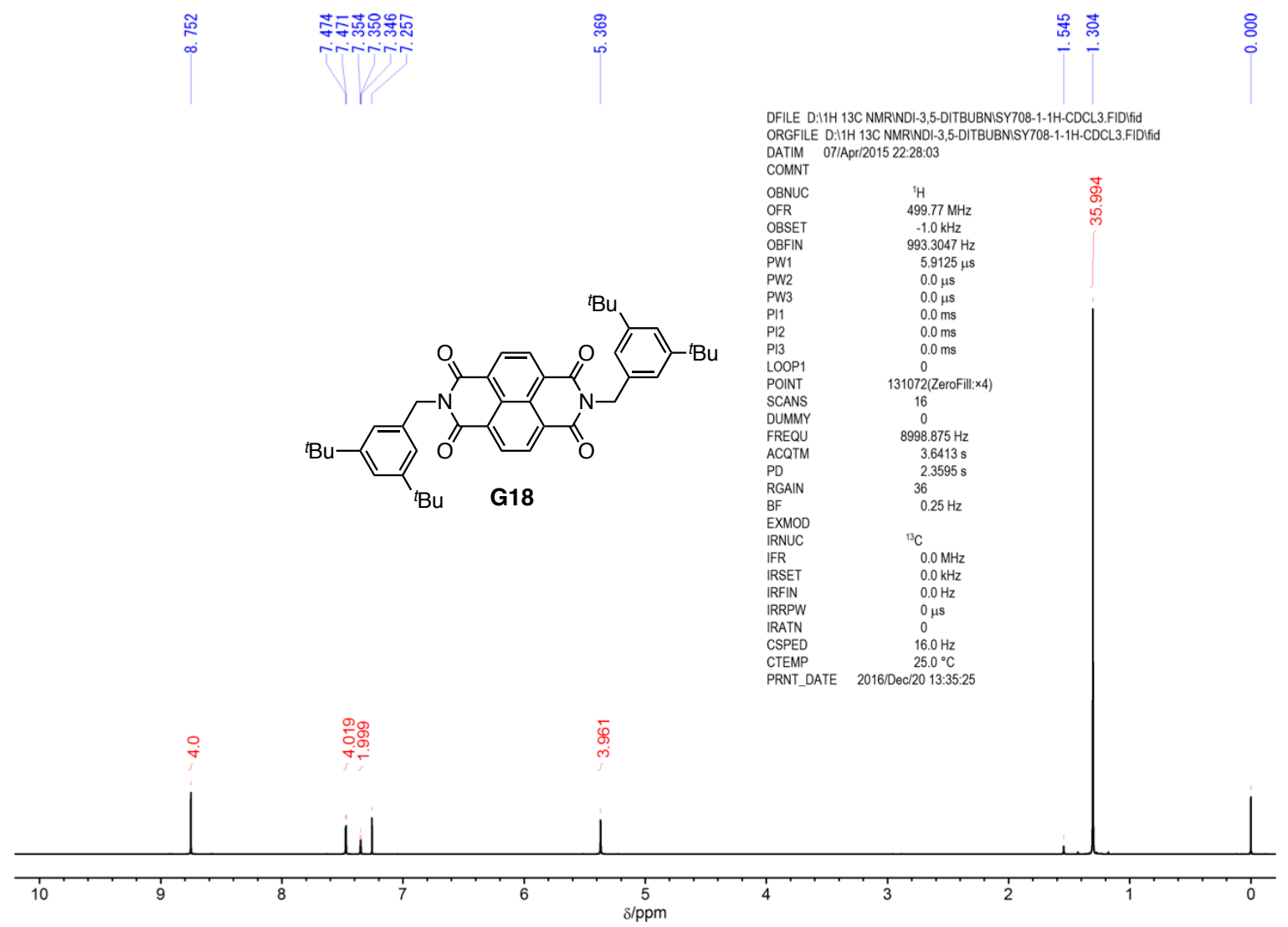

Figure S53. ${ }^{1} \mathrm{H}$ NMR spectrum of $\mathbf{G 1 8}$ in $\mathrm{CDCl}_{3}$ at $25^{\circ} \mathrm{C}$.

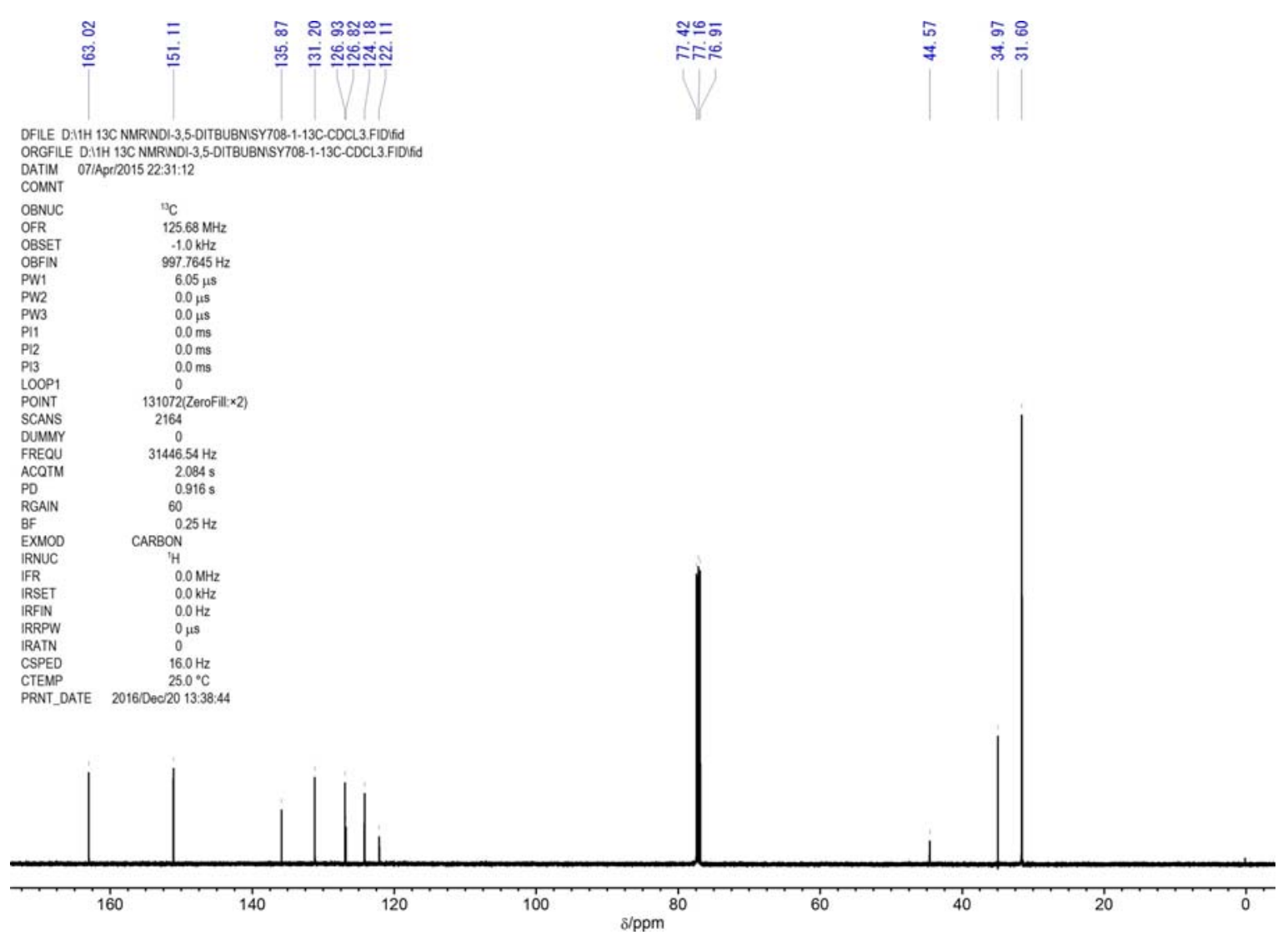

Figure S54. ${ }^{13} \mathrm{C}\left\{{ }^{1} \mathrm{H}\right\}$ NMR spectrum of $\mathbf{G 1 8}$ in $\mathrm{CDCl}_{3}$ at $25{ }^{\circ} \mathrm{C}$. 


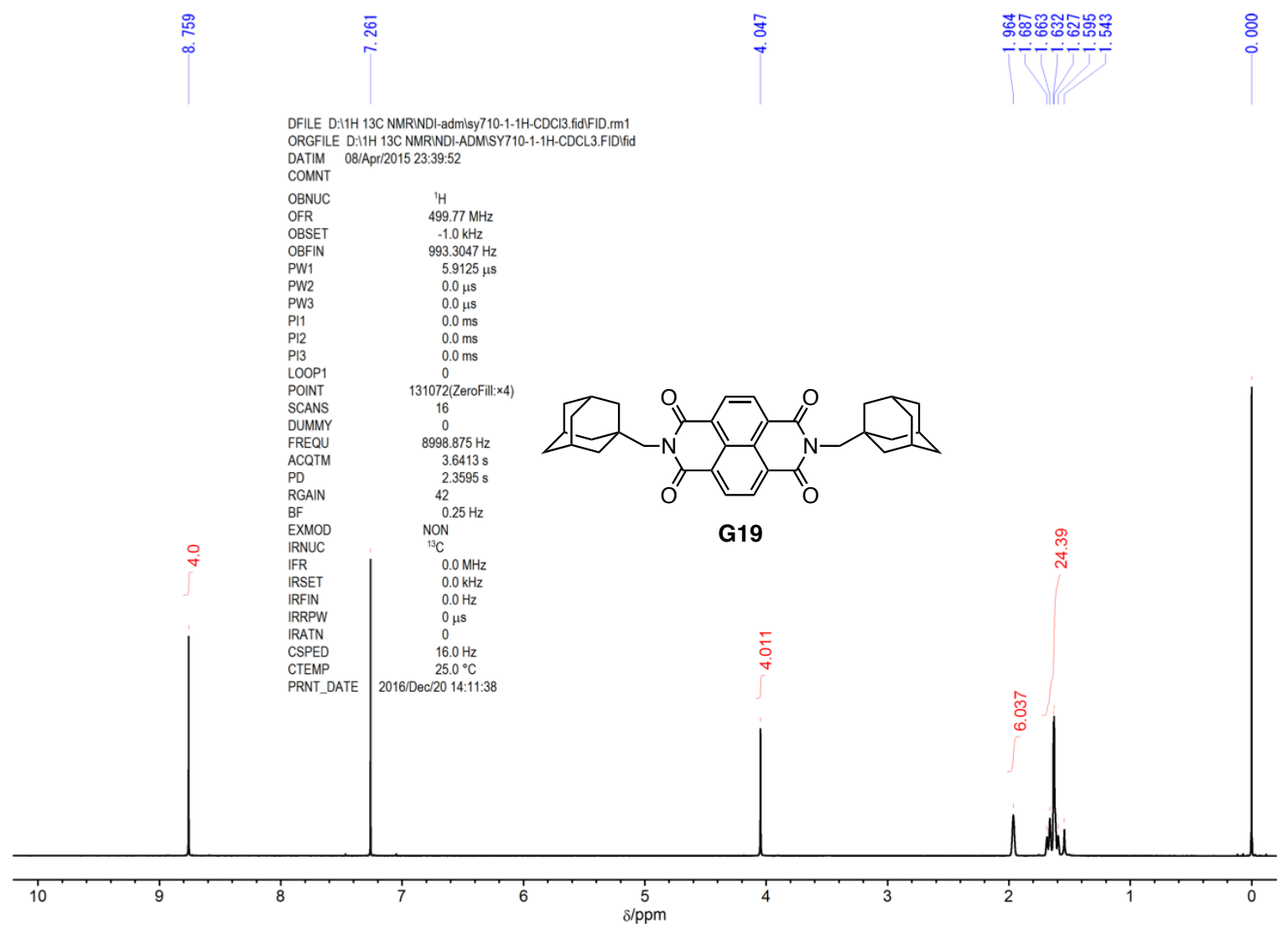

Figure S55. ${ }^{1} \mathrm{H}$ NMR spectrum of $\mathbf{G 1 9}$ in $\mathrm{CDCl}_{3}$ at $25^{\circ} \mathrm{C}$.

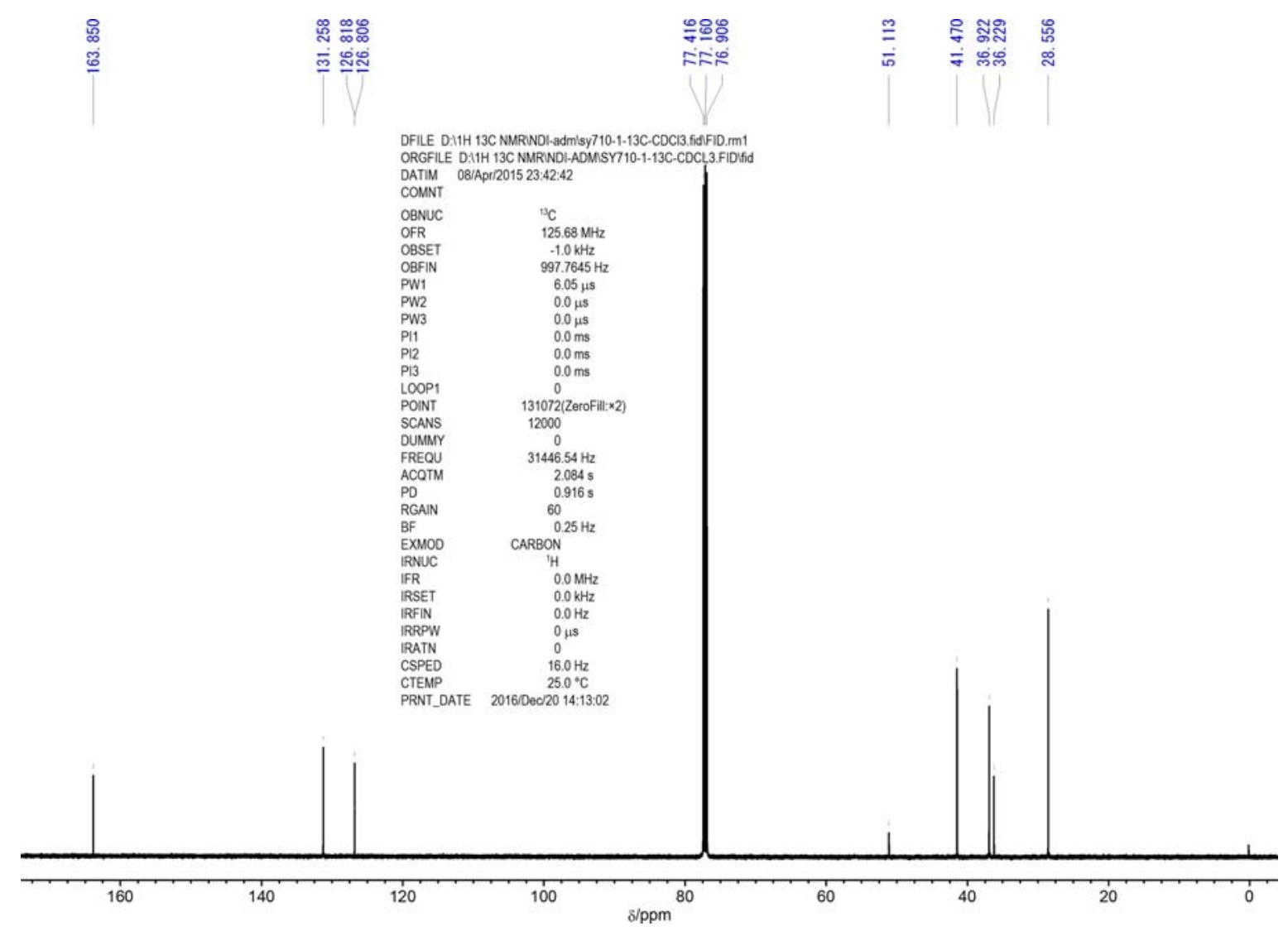

Figure S56. ${ }^{13} \mathrm{C}\left\{{ }^{1} \mathrm{H}\right\}$ NMR spectrum of $\mathbf{G 1 9}$ in $\mathrm{CDCl}_{3}$ at $25{ }^{\circ} \mathrm{C}$. 